\title{
SPECIES OF THE GENUS PSEUDONIPHARGUS CHEVREUX, 1901 (AMPHIPODA) FROM THE BETIC CORDILLERA OF SOUTHERN SPAIN*
}

\author{
by
}

\author{
JOS NOTENBOOM \\ Institute of Taxonomic Zoology, University of Amsterdam, \\ P.O. Box 20125, 1000 HC Amsterdam, The Netherlands
}

\begin{abstract}
The genus Pseudoniphargus, up to now represented in southern Spain by a single species, branchiatus Stock, appears to be widely distributed in the area. Through the present study, based on new collections obtained in 1984 and 1985, a total of 15 species is recognized.

The distribution of Pseudoniphargus in the south of Spain seems to coincide with the Betic Cordillera, which is a structural geological entity with important influences of the sea during the Late Cretaceous or Tertiary. Most of the species are allopatric and have very limited distributions. However, in the Guadalquivir basin one species, latipes $\mathbf{n}$. sp., is widely distributed while three local species, vomeratus n. sp., cazorlae n. sp. and illustris n. sp., occur within the range of latipes.

The morphological interspecific diversity in general is greater than between the species of northern Spain. The southern species cannot be characterized as a whole by a single character or a set of characters, although some characters (e.g. elongate uropod 3 male, narrow basis of posterior pereiopods) tend to be present more frequently in south Spanish species than in other species of the genus.
\end{abstract}

\section{RESUMEN}

El género Pseudoniphargus, que hasta ahora únicamente estaba representado en el sur de España por una especie: branchiatus Stock, parece hallarse ampliamente distribuido en esta área. En el contexto del presente estudio, basado en nuevas recolecciones efectuadas en 1984 y 1985, se han reconocido un total de 15 especies.

La distribución de los Pseudoniphargus en el sur de España parece coincidir con la Cordillera Bética, la cual constituye una entidad geológica y estructural que estuvo sometida a importantes influencias del mar hacia finales del Cretácico o del Terciario. Muchas de las especies son alopátricas y muestran distribuciones muy limitadas. Sin embargo, una de las especies: latipes n. sp., se halla ampliamente distribuida en la cuenca del Guadalquivir, mientras que otras tres especies locales: vomeratus $\mathrm{n}$. sp., cazorlae n. sp. e illustris n. sp., coinciden en la misma área de latipes.

* Groundwater crustaceans of Spain, 5.
La diversidad morfológica interespecífica en general es más acusada que en las especies del norte de España. Las del sur no pueden ser tipificadas como grupo definido en base a uno o a varios caracteres, aunque algunas características (por ejemplo, el tercer urópodo del macho alargado, los bases de las patas posteriores estrechos) tienden a estar presentes de manera más frecuente en especies del sur de España que en otras especies del género.

\section{INTRODUCTION}

In a recent study on the species of Pseudoniphargus from northern Spain (Notenboom, 1986), the disjunct distribution of these stygobiont amphipods in Iberian continental groundwaters was noted. The subject of this paper is the systematics of the geographically coherent group of south Spanish species.

The occurrence of the stygobiont amphipod Pseudoniphargus in groundwaters of southern Spain was recorded for the first time by Margalef (1970), who mentioned merely its existence in a cave near Baena (Córdoba). Stock (1980) described one new species, Ps. hranchintus. from two localities, the underflow of the Río Júcar at its mouth near Cullera (Valencia) and cave waters of the Hudidero-Gato system near Ronda (Málaga). These localities, which appeared to be situated at the southwesternmost and southeasternmost part of the Iberian distribution of the genus, are some $450 \mathrm{~km}$ remote.

The collections on which the present study is almost entirely based were obtained during recent investigations of Spanish groundwaters. The first Pseudoniphargus were discovered by us in spring and summer of 1984 (Notenboom \& Meijers, 1985). Important collections were 
obtained in summer 1985 by P. van den Hurk and R. Leys (unpublished) in the western part of Andalusia, while in the same year Notenboom and Meijers (unpublished) did some additional fieldwork in east Andalusia, Murcia and Valencia. In the taxonomic section of this paper the stations investigated by the fellow workers P. van den Hurk and R. Leys are numbered beginning with " $A$ ".

During this study 14 new species have been recognized in addition to the formerly known Ps. branchiatus Stock, 1980. The paratypes of the latter species, originating from the HundideroGato cave system, are now considered as belonging to an independent species. The present paper and that of Notenboom (1986) show that the Iberian Pseudoniphargus species are all endemic to each of their disjunct distribution areas. Likewise the studies show a very localized distribution of many species of Pseudoniphargus.

A generality in Pseudoniphargus is the close resemblance of many of the forms distinguished and the morphological difference of almost each isolated population. Therefore morphological differences encountered between individuals of separated samples are often difficult to interprete as inter- or intraspecific. Within the species treated in this paper these problems are found in particular in grandis, fragilis, and affinis.

In this context it is important to realize that the new taxa of this paper are described as morphological species. Moreover, little information is available, apart from their morphology, to decide whether they are "real" biological species or not. Not completely reproductively isolated populations of (semi)species are capable of interbreeding in cases of secondary contact. Such intermediate forms are difficult to recognize and to classify on morphological grounds alone with material originating from scattered localities. Through this systematic study we hope to get a framework for further studies on speciation and evolution of these zoogeographically interesting animals.

A key to the Iberian species of Pseudoniphargus was prepared for this paper. However, since a new species of the genus was recently discovered in west Galicia (N.W. Spain), this key will be presented in another paper describing this new species and including remarks on the Portuguese species.

\section{GEOGRAPHICAL DISTRIBUTION}

The distribution of Pseudoniphargus in southern Spain seems to coincide with the Betic Cordillera, which includes the Guadalquivir basin as well (fig. 1). Whether the Betics really encompass the range of Pseudoniphargus remains uncertain due to the absence of data from the Sierra Morena. These mountains form the southern delimitation of the Paleozoic Meseta (the central plateau of Spain) directly abutting on the ancient Guadalquivir trough. Nevertheless, sampling at the western and eastern boundaries of the Betic Cordillera seems to indicate a limitation of the distribution of Pseudoniphargus in southern Spain to this mountain range.

West of the Guadalquivir basin groundwater biotopes were investigated in the province of Huelva. In particular wells and underflows of rivers were sampled in the lower coastal areas as well as in the Sierra de Arcena, situated more inland. Several stygobiont crustaceans were encountered such as asellote isopods, microparasellids and bathynellids; however, amphipods seem to be absent from this area (unpublished data, Van de Hurk and Leys). Moving more eastward the first stygobiont amphipods were found just east of the town of Sevilla, viz. of the genera Metahadzia, Haploginglymus, and Pseudoniphargus.

During the intensive groundwater sampling program in the province of Valencia and adjacent areas (Notenboom \& Meijers, 1985) the presence of Pseudoniphargus was established in the southern part of Valencia only. North of this area many stygobiont crustaceans were found, such as asellote isopods, microparasellids, bathynellids, and the amphipods Haploginglymus, Salentinella, and Bogidiella. But Pseudoniphargus was lacking. 
The Betic Cordillera forms the western end of the great European Alpine chains, and includes the Balearic Islands as well. In contrast to the areas abutting on the Betic Cordillera in the north, the Betics have a very complicated Cretaceous to Late Tertiary history which is not yet thoroughly known. The structure of the Betic Range results essentially from large-scale overthrusting and strike-slip faulting, related to the relative movements of the African and European plates.

Large parts of the Betics were influenced by the important, widespread Burdigalian transgression at the beginning of the Miocene. Prior to the Miocene the area was subjected to important tectonic movements with as consequence hardly traceable patterns of marine trans- and regressions of earlier eras. Since the midMiocene the Betic Cordillera developed into an archipelago from which the sea more or less gradually retreated between Tortonian to Pliocene. In the Tortonian and Messinian at the end of the Miocene the sea influenced still some of the major interior depressions and many smaller basins along the coast (Montenat, 1977; Völk, 1967; Weijermars et al., 1985). The strongly fossiliferous marine sediments with an important shallow-water fauna show that the Mediterranean formerly opened through the Betics and the North African Rif into the Atlantic, with evidence that the faunas were alternatively influenced by the ocean or by the pre-Mediterranean (Ager, 1980). During the Pliocene marine transgressions took place only in the basin of the Guadalquivir and several smaller coastal basins. In many coastal areas of low altitude marine influences of Pleistocene age cannot be excluded, but these are not very likely due to the general uplift these areas underwent.

The rather young, extremely complex geological history of the Betic Cordillera has given rise to a diversified geological subsoil resulting in a varied present geography, which is a very modern phenomenon. Large parts of the western Betic Cordillera drain into the Río Guadalquivir with its important tributary, the Río Genil. In the southeastern part of the Betic
Range a large area is drained by the Río Segura and its tributaries, e.g. the Río Mundo. The southern part of the area is drained by numerous short and fast-flowing rivers, a consequence of the proximity of the seacoast to the high "sierras". Many of the minor rivers are intermittent or dry during years with little precipitation. Important phreatic groundwater occurrences are found in the karst of the numerous calcareous "sierras", in the vast Quaternary deposits in the larger river basins and coastal plains, and in local alluvia of smaller dry or river valleys, reaching to rather high altitudes.

Most of the species treated in this paper are found in hyporheic habitats and wells, which form the most frequently investigated groundwaters. The few springs and caves investigated yielded Pseudoniphargus as well. Hyporheic habitats where Pseudoniphargus species have been encountered were in general situated in the upper parts of the river basins, at altitudes of up to $1400 \mathrm{~m}$ (viz. Río Trevélez with Ps. nevadensis at the southern slopes of the Sierra Nevada).

Wells situated in areas with thick clayey and silty deposits made in phreatic aquifers of usually low porosity are less favourable for groundwater fauna. Therefore, no good samples were obtained in parts of the Guadalquivir River basin, between Córdoba and Jaén, and downstream of Sevilla. Species of Pseudoniphargus were generally collected in wells situated in alluvial sediments at higher altitudes in the proximity of riverbeds.

Limestone areas are extensive in the Betic Cordillera, and probably contain important karst aquifers. However, few biotopes related to these aquifers, such as karst springs and cave waters, have been sampled, due to the deep drainage of the karst and the difficulties of reaching the karst waters. Altogether six water caves were visited within the south Iberian range of Pseudoniphargus, in four of which Pseudoniphargus was encountered. As to the eight karst springs sampled, six revealed specimens of Pseudoniphargus.

Most of the species are allopatric and seem to 


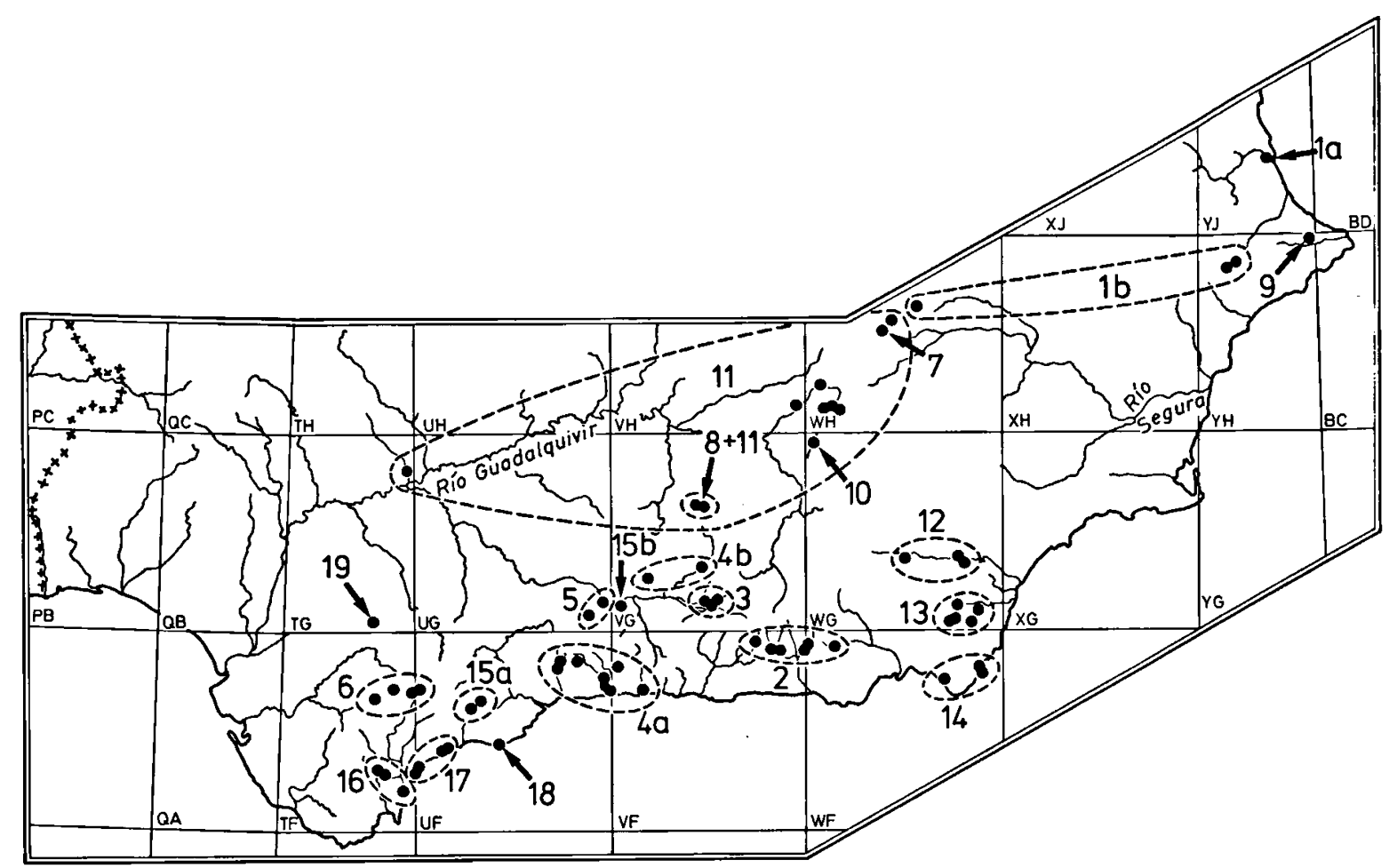

Fig. 1. Distribution of Pseudoniphargus species in southern Spain: 1a, branchiatus Stock, 1980; 1b, cf. branchiatus; 2, nevadensis n. sp.; 3, granadensis n. sp.; 4a, grandis n. sp.; 4b, cf. grandis; 5, affinis n. sp.; 6, stocki n. sp.; 7, vomeratus n. sp.; 8, illustris n. sp.; 9, margalefi $\mathrm{n}$. sp.; 10, cazorlae $\mathrm{n}$. sp.; 11, latipes $\mathrm{n}$. sp.; 12, gracilis $\mathrm{n}$. sp.; 13, sorbasiensis $\mathrm{n}$. sp.; 14 , sp. $2 ; 15 a$, fragilis n. sp.; 15b, cf. fragilis; 16, gibraltaricus n. sp.; 17, sp. 3; 18, sp. 4; 19, sp. 5. Map provided with universal transverse mercator (UTM) grid, $100 \times 100 \mathrm{~km}$ squares indicated by letter codes.

have limited geographical distribution areas, a pattern found in northern Spain as well (Notenboom, 1986). However, in southern Spain some exceptions to this pattern are found in the Guadalquivir basin. In hyporheic waters of this area latipes has a large distribution. Moreover, three other species, vomeratus, cazorlae and illustris, are found in one or two nearby localities only, but within the range of latipes. Ps. illustris co-occurs at both of its localities with latipes. Co-occurrences of species of Pseudoniphargus are very rare, and this phenomenon was recently mentioned for the first time by Stock et al. (1986) with respect to the two Bermudian species, grandimanus and carpalis.

Specimens considered as Ps. cf. branchiatus found in wells near Alcoy and in the underflow of the about $170 \mathrm{~km}$ remote Río Mundo show only small morphological differences, suggesting a rather large distribution area of this species. Ps. grandis is distributed in hyporheic habitats, wells and cave waters in a small area east and north of Málaga. However, the species seems to have two disjunct populations, which are slightly different morphologically, in karst springs north and east of Granada (Manantial de Allomartes and Manantial de Deifontes). Another example of disjunct distribution is found in fragilis which occurs in a hyporheic habitat and a well near Tolox (Málaga), but is represented by a slightly different population in a hyporheic habitat near Salar (Granada).

Other species treated in this paper have small and isolated distribution areas, often restricted to one valley or a single mountain range. Species limited to a single river valley are gracilis in phreatic waters of the Río Almanzora 
valley, sorbasiensis in the basin of the Río de Aguas around Sorbas, granadensis in hyporheic waters of the upper part of the Río Genil basin near Granada, cazorlae in the undertlow of the uppermost part of the Río Guadalquivir in the Sierra de Cazorla and illustris in similar habitats of the Río Guadalbullón near Carchelejo and Cambil (Jaén).

Mountain ranges which appear to harbour localized species of Pseudoniphargus are the Sierra Nevada, with nevadensis occurring in the underflow of several rivers at the southern slopes, the Serranía de Ronda in which stocki is found in cave waters and wells, and the Sierra Gorda with affinis found in the outflow of karstic drainages. Moreover, margalefi is found in the drainage of the karst in which the Cueva de Calaveras near Benidoleig (Valencia) is located.

Some species are distributed in small areas without an obvious connection to a river basin or a mountain drainage. For instance grandis has been found in several types of groundwaters northeast of Málaga, fragilis around Tolox (Málaga), and gibraltaricus in a small area just north of Gibraltar.

\section{ECOLOGICAL REMARKS}

During the fieldwork for the present study some physical and chemical parameters of the sampled groundwater habitats were determined (temperature, chlorinity, conductivity, $\mathrm{pH}$, and oxygen content). The methods used, and part of the results, are presented in Notenboom \& Meijers (1985); other results are unpublished. In general, groundwaters in southern Spain have, when compared with those of the northern range of Pseudoniphargus (roughly the Cantabrian Mountains), higher temperatures and conductivities, whereas the chlorinity of inland localities is slightly higher.

Wells generally have higher conductivities and chlorinities than other inland groundwater habitats. These parameters depend on domestic pollution influencing the wells, and the lithology of the aquifer. For example around
Sorbas (Almería), in an area with important deposits of gypsum, chlorinities of $680 \mathrm{mg} / \mathrm{l}$ and conductivities of $4.95 \mathrm{mS} / \mathrm{cm}$ were found at altitudes of about $300 \mathrm{~m}$.

Most noteworthy is the large range of oxygen contents in habitats of Pseudoniphargus sampled in the same month (July). On the lower end of the range, Pseudoniphargus sp. 3 in the underflow of the Arroyo de la Jornada (Málaga) lived at an oxygen content of $0.5 \mathrm{mg} / \mathrm{l}$, and grandis in a well near Los Vados (Málaga) of $0.7 \mathrm{mg} / \mathrm{l}$. At the higher end of the range we found Ps. cf. affinis in Fuente la Carmonilla near Loja (Granada) $(11.4 \mathrm{mg} / \mathrm{l})$ and stocki in running cave waters of the Hundidero-Gato system near Ronda (Málaga) (10.1 mg/l).

The records for each species from different kinds of habitats are listed in table I. It would be premature to draw conclusions about habitat preference of the species. Preferences suggested by this table appear to depend more on the number of different habitats sampled within a certain range of a species. Nevertheless, latipes and nevadensis are two species with a large distribution in hyporheic habitats of the Guadalquivir basin and streams arising on the southern slopes of the Sierra Nevada, respectively.

Several other stygobiont malacostracan crustaceans occur in southern Spain along with species of Pseudoniphargus. Many of these are found in the whole range of Pseudoniphargus. An exception might be the isopod Typhlocirolana, which is found in few localities at the eastern part of the range of Pseudoniphargus only (see Notenboom \& Meijers, 1985), and a new still undescribed amphipod probably limited to groundwaters of the Guadalquivir basin. Table II enumerates the number of co-occurrences of Pseudoniphargus with other stygobiont crustaceans in the different biotopes. Table III shows the number of co-occurrences per species of Pseudoniphargus. The co-occurrence of several of these faunal elements is mainly determined by the biotope sampled (see table II). Salentinella (Amphipoda) has been found together with several species of Pseudoniphargus in wells only, while Bogidiella (Amphipoda) is found almost 
TABLE I

Records of species of Pseudoniphargus from different kinds of habitats (based on records mentioned in this paper) Individuals classified provisionally to the species are included as well.

\begin{tabular}{|c|c|c|c|c|c|c|c|}
\hline & \multirow{2}{*}{$\begin{array}{l}\text { hyporheic } \\
\text { habitats* }\end{array}$} & \multirow[t]{2}{*}{ wells } & \multicolumn{2}{|c|}{ springs } & \multicolumn{2}{|r|}{ caves } & \multirow{2}{*}{$\begin{array}{c}\text { mine gallery } \\
\text { pools }\end{array}$} \\
\hline & & & karst & others & streams & phreatic lakes & \\
\hline branchiatus & 2 & 2 & & & & & \\
\hline nevadensis & 7 & & & & & & \\
\hline granadensis & 3 & & & & & & \\
\hline grandis & 4 & 5 & 1 & & & 1 & \\
\hline affinis & & & 1 & & & & 1 \\
\hline stocki & & 4 & & & 1 & & \\
\hline vomeratus & & & & 1 & & & \\
\hline illustris & 2 & & & & & & \\
\hline margalefi & & & 1 & & & & \\
\hline cazorlae & 1 & & & & & & \\
\hline latipes & 9 & 1 & & & & & \\
\hline gracilis & & 3 & & & & & \\
\hline sorbasiensis & & 4 & & & 1 & & \\
\hline fragilis & 2 & 1 & & & & & \\
\hline gibraltaricus & 1 & 2 & & & & & \\
\hline
\end{tabular}

* Including the hyporheic habitat of karst springs.

exclusively in hyporheic waters together with Pseudoniphargus. The asellote isopod Proasellus was found most frequently together with Pseudoniphargus. The stygobiont amphipod indicated in the tables as "new undescribed Amphipoda" is closely related to Pseudoniphargus and probably endemic to the Guadalquivir basin. It is often found with latipes and in one locality even together with illustris and latipes.

\section{RELATIONSHIPS WITH SPECIES FROM OTHER AREAS}

The whole group of south Spanish species of Pseudoniphargus treated in this paper cannot be characterized by a single character or a set of morphological features. Comparing the species from the south with those from the north some tendencies in distribution of morphological characters can be recognized. However, some overlap between the two areas exists. South Spanish species have in general medium deep coxal plates, the posterior excavation of coxa 4 very shallow or absent, a non-elongated claw of pereiopod 4, a narrow basis of pereiopods 5-7 without overhanging posterodistal corner, the ventral margin of epimeral plates 2 and 3 provided with a couple of spines, the peduncle of uropod 1 with medial and several dorsal spines, and a telson provided with a good number of terminal spines. Moreover, a large number (8) of southern species have the exopodite of uropod 3 elongated while in the north only elongatus shows such elongation.

In the southern group more aberrant morphological features have been found than in the other species of the genus. Moreover, they are morphologically more diverse than in northern Spain, where for example the general morphology is much more uniform. Some southern species possess features never mentioned in their congeners: the sexually dimorphic telson in vomeratus, the widened propodus of gnathopod 1 in latipes, the strongly spinose telson in grandis, and the very slender gnathopods in gracilis. Other species, viz. gibraltaricus, margalefi, fragilis, cazorlae, and affinis, are weakly characterized and therefore 
TABle II

Records of Pseudoniphargus (in contradistinction to table I this table includes juvenile unidentifiable specimens as well) from different habitats mentioned in this paper and number of co-occurrences with other stygobiont malacostracan crustaceans in different habitats.

\begin{tabular}{lcccc}
\hline & $\begin{array}{c}\text { hyporheic } \\
\text { waters }\end{array}$ & wells & springs & $\begin{array}{c}\text { cave } \\
\text { waters, } \\
\text { mine } \\
\text { gallery } \\
\text { pools }\end{array}$ \\
\hline $\begin{array}{l}\text { Pseudoniphargus } \\
\text { Haploginglymus }\end{array}$ & 39 & 28 & 6 & 4 \\
Salentinella & 10 & 3 & 1 & \\
$\begin{array}{l}\text { Bogidiella } \\
\text { Microparasellidae }\end{array}$ & 13 & 2 & & \\
$\begin{array}{l}\text { Proasellus (blind) } \\
\text { Stenasellus }\end{array}$ & 23 & 2 & & \\
$\begin{array}{l}\text { Bathynellacea } \\
\text { Typhlocirolana }\end{array}$ & 2 & 2 & 1 & 3 \\
"undescribed new & 6 & 1 & & \\
Amphipoda" & & 1 & & \\
\hline
\end{tabular}

\section{TABLE III}

Co-occurrences of Pseudoniphargus species with other stygobiont malacostracan crustaceans $(n=$ total number of different habitats sampled per species). Two species, $P$ s. margalefi $(n=1)$ and gibraltaricus $(n=3)$, were not found together with other stygobiont malacostracans.

\begin{tabular}{|c|c|c|c|c|c|c|c|c|c|c|}
\hline & & 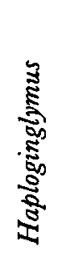 & 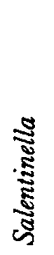 & 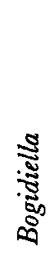 & 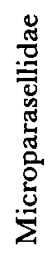 & 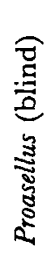 & 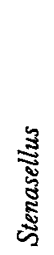 & 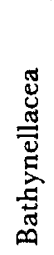 & 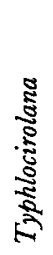 & 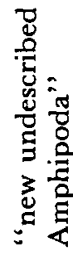 \\
\hline branchiatus & $(n=3)$ & 2 & 1 & & 1 & 1 & & & & \\
\hline nevadensis & $(n=7)$ & & & 3 & 1 & 4 & & 1 & & \\
\hline granadensis & $(n=3)$ & & & 1 & 1 & 2 & & & & \\
\hline grandis & $(n=11)$ & 1 & 2 & 4 & 3 & 3 & & 1 & & \\
\hline affinis & $(n=2)$ & & & & & 1 & & & & \\
\hline stocki & $(n=5)$ & & & & & 1 & & & & \\
\hline vomeratus & $(n=1)$ & 1 & & & & & & & & \\
\hline illustris* & $(n=2)$ & 2 & & 1 & 1 & 1 & & 1 & & 1 \\
\hline cazorlae & $(n=1)$ & 1 & & & & 1 & & & & \\
\hline latipes* & $(n=10)$ & 6 & 1 & 2 & 1 & 7 & 3 & 1 & & 6 \\
\hline gracilis & $(n=3)$ & & 2 & 1 & & 2 & & 1 & 1 & \\
\hline sorbasiensis & $(n=5)$ & & 1 & & & 2 & 1 & & & \\
\hline fragilis & $(n=3)$ & & & & & 2 & & & & \\
\hline
\end{tabular}

* Ps. illustris was found together with latipes at both its localities. more problematic. They do not possess unique characters but various combinations of "existing" characters.

Remarkable is the group of species (branchiatus, nevadensis, granadensis, grandis, affinis, stocki, vomeratus, and illustris) with a strongly elongated and upcurved exopodite of uropod 3 in the male. This character has been found in some other species of the genus as well, viz. elongatus from northern Spain, africanus and macrotelsonis from Algeria, and adriaticus from littoral interstitial waters in the northern belt of the Mediterranean. In addition this south Spanish group has a narrow basis in pereiopods 5 to 7 , medium deep coxal plates and a rather spinose telson, a combination of characters not found in other species of Pseudoniphargus.

Noteworthy are some similarities to North African taxa. The male of Ps. vomeratus has an enlarged telson similar to that of macrotelsonis from Algeria, a character which has not been found in any other species of the genus. Reexamination of the types of macrotelsonis showed that the female telson, as in vomeratus, is shorter and more like that of the other species of the genus. The resemblance in morphology, in particular that of the telson, between Pseudoniphargus sp. 2 and an unidentified species of Stock (1980) from the Rhar-el-Khal cave near Khemis in Algeria might point to another North African relationship. Unfortunately the material from both localities is scarce and possibly immature, so more extensive collecting is necessary to prove this supposition.

Recently Boutin \& Coineau (in press) described Ps. maroccanus, the first species of the genus from Morocco. In several features this species is reminiscent of the south Spanish group, especially of fragilis, e.g. by the medium deep coxal plates, narrow basis of pereiopods 5 to 7 , and numerous spines on pereiopods, uropods, and telson.

\section{TAXONOMIC PART}

Genus Pseudoniphargus Chevreux, 1901

Recently Stock (1980) has given a more extensive diagnosis of the genus without changing 
the original concept of Chevreux (1901). To this generic concept Notenboom (1986) added, after studying the species of northern Spain, a gill stalk appearing somewhat longer in females than in males, the presence of a membranous cushion on the posterior margin of the merus of gnathopod 1, the constant presence of a group of midpalmar setae on the gnathopods, and the occasional presence of sexual differences in gnathopods, as well as the elongation of the carpus in gnathopod 2. The present study shows that the number of spines on the outer lobe of maxilla 1 usually is 7 , but sometimes 6 or 8 .

All materials on which this study is based are deposited in the Zoölogisch Museum, Amsterdam (ZMA).

\section{Pseudoniphargus branchiatus Stock, 1980 (Figs. 2-3)}

Material examined. - Prov. Valencia, Cullera, mouth of the Río Júcar about $500 \mathrm{~m}$ from the sea, UTM coordinates YJ382375; 9 Sept. 1970, 1 ovigerous $\$$ holotype, leg. J. H. Stock \& S. Pinkster (ZMA coll. no. Amph. 106.154).

Prov. Alicante, SBR ** Río Mundo, $5 \mathrm{~km}$ downstream of Fabricas de Ríopar, near bridge in the road to Elche de la Sierra, UTM coordinates WH56, alt. about $1000 \mathrm{~m} ; 17$ July 1985 (sta. 85-7/5), about 100 specimens (probably this species).

Prov. Alicante, Alcoy, well at Casa de la Monja, partida San Benet bajo, UTM coordinates YH187854, alt. $560 \mathrm{~m} ; 3$ March 1984 (sta. 84-3/6), 1 \%, 6 ९९ (1 ovigerous), and 5 juvs. (probably this species).

Prov. Alicante, Alcoy, well at Chalet de Albors, Batoy, UTM coordinates YH171847, alt. $630 \mathrm{~m} ; 3$ March 1984 (sta. 84-3/8), 3 ơ $0^{\circ} 9$ \& (3 ovigerous), and 2 juvs. (probably this species).

Remarks. - The holotype designated by Stock (1980) is a small ovigerous female, the only specimen collected from the underflow of the Río Júcar near Cullera. Specimens (males and larger ovigerous females) from a locality $450 \mathrm{~km}$ remote of the type-locality were attributed by Stock to the same species and designated as paratypes. This recognition was

\footnotetext{
** SBR indicates samples taken from the underflow of rivers (hyporheic habitats) by means of the phreatic or Bou-Rouch pump.
}

particularly based on the long female gill stalk, a character which Stock (1980) thought to be unique of this species.

Our study shows that a long gill stalk in the female and a short stalk in the male is found in all species, thus this character has no diagnostic importance whatsoever within the genus.

In southern Spain a group of closely related species (branchiatus, nevadensis, granadensis, grandis, affinis, and stocki) is characterized by the elongation of uropod 3 in the male, slender gnathopod 1, slender basis of posterior pereiopods with straight margins and narrow non-overhanging posterior lobe, not strongly pointed posteroventral corner of epimera, pereiopod 5 somewhat longer than pereiopod 4 , coxa 4 hardly posteriorly excavate and long spines on exopodite of female uropod 3. Differences between the species of this group (henceforth called the branchiatus group) reside in shape and armature of the telson, elongation and armature of peduncle of male uropod 3, armature of uropods 1 and 2, shape of epimera, and shape of coxae 3 and 4 .

Because of the absence of males from the type-locality of branchiatus (cf. Stock, 1980) we tried to get topotypic material or material from nearby localities. Unfortunately the Río Jucar near Cullera appeared to be recently canalized and now has slimy banks through which sampling of its underflow was impossible; furthermore several other groundwater biotopes sampled in the region (mostly wells) did not contain any Pseudoniphargus (cf. Notenboom \& Meijers, 1985).

The material of Pseudoniphargus from Alcoy and Río Mundo probably belongs to this species, since the holotype resembles more or less females of the same size $(4.2 \mathrm{~mm})$ from these localities. This similarity is more convincing than with other females of the branchiatus group or other species of Pseudoniphargus. Differences, which might be considered as intraspecific variation, between the holotype and females from Alcoy and Río Mundo are found in the length of the spines on the exopodite of uropod 3, the armature of the lower margins of the epimeral plates, and the 


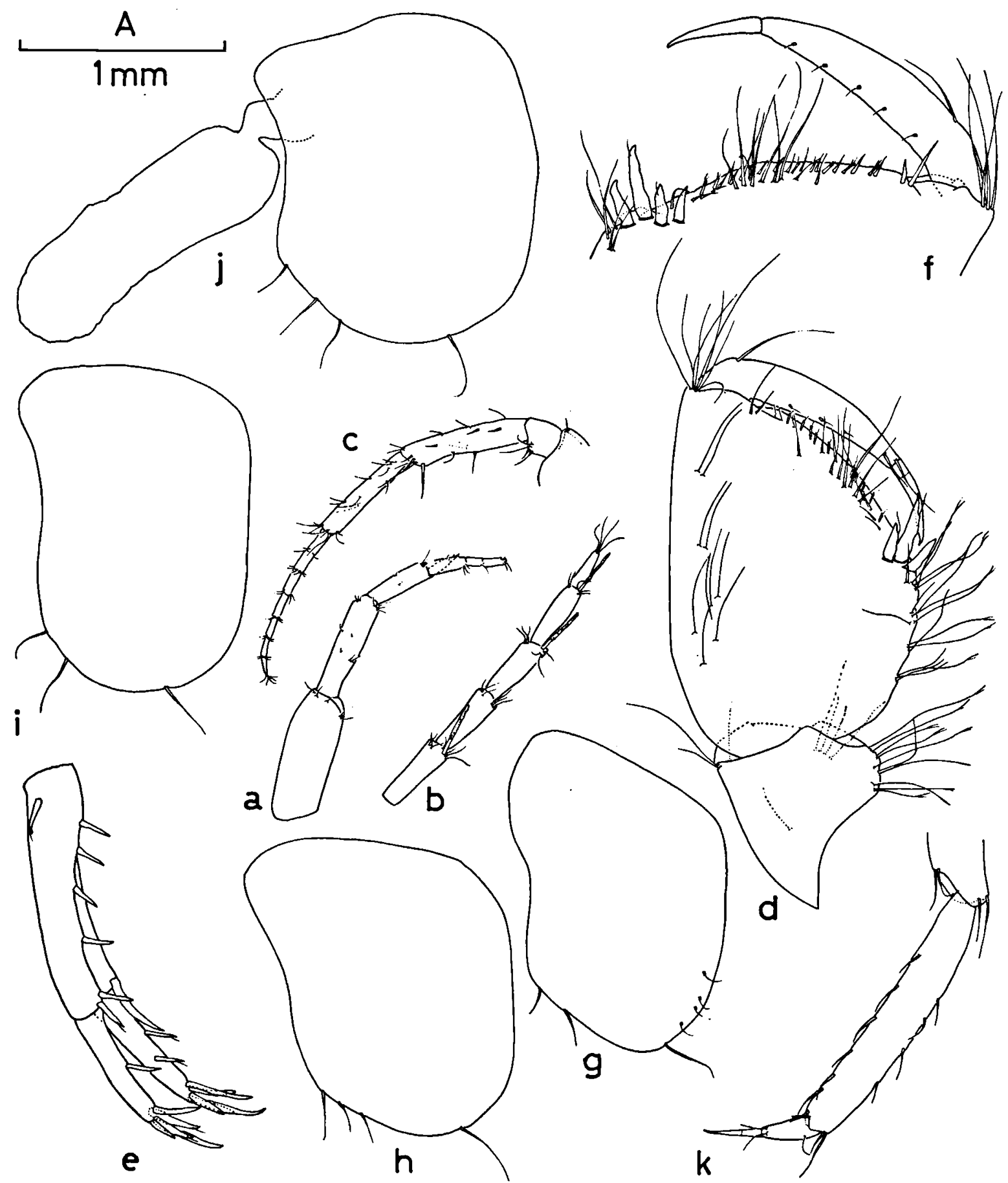

Fig. 2. Pseudoniphargus cf. branchiatus Stock, 1980 (a-e, o $6.2 \mathrm{~mm}$, from Casa de la Monja near Alcoy; f-k, O $8.5 \mathrm{~mm}$, from Río Mundo): a, peduncle antenna 1 (scale A); b, distal part of flagellum antenna 1 (B); c, antenna 2 (A); d, distal part of gnathopod 2 (B); e, uropod 1 (O); f, palmar margin propodus of gnathopod 2 (B); g, coxal plate gnathopod 1 (B); h, coxal plate gnathopod 2 (B); i, coxal plate pereiopod 3 (B); j, coxal plate pereiopod 4 (B); $k$, distal part pereiopod 4 (B). 


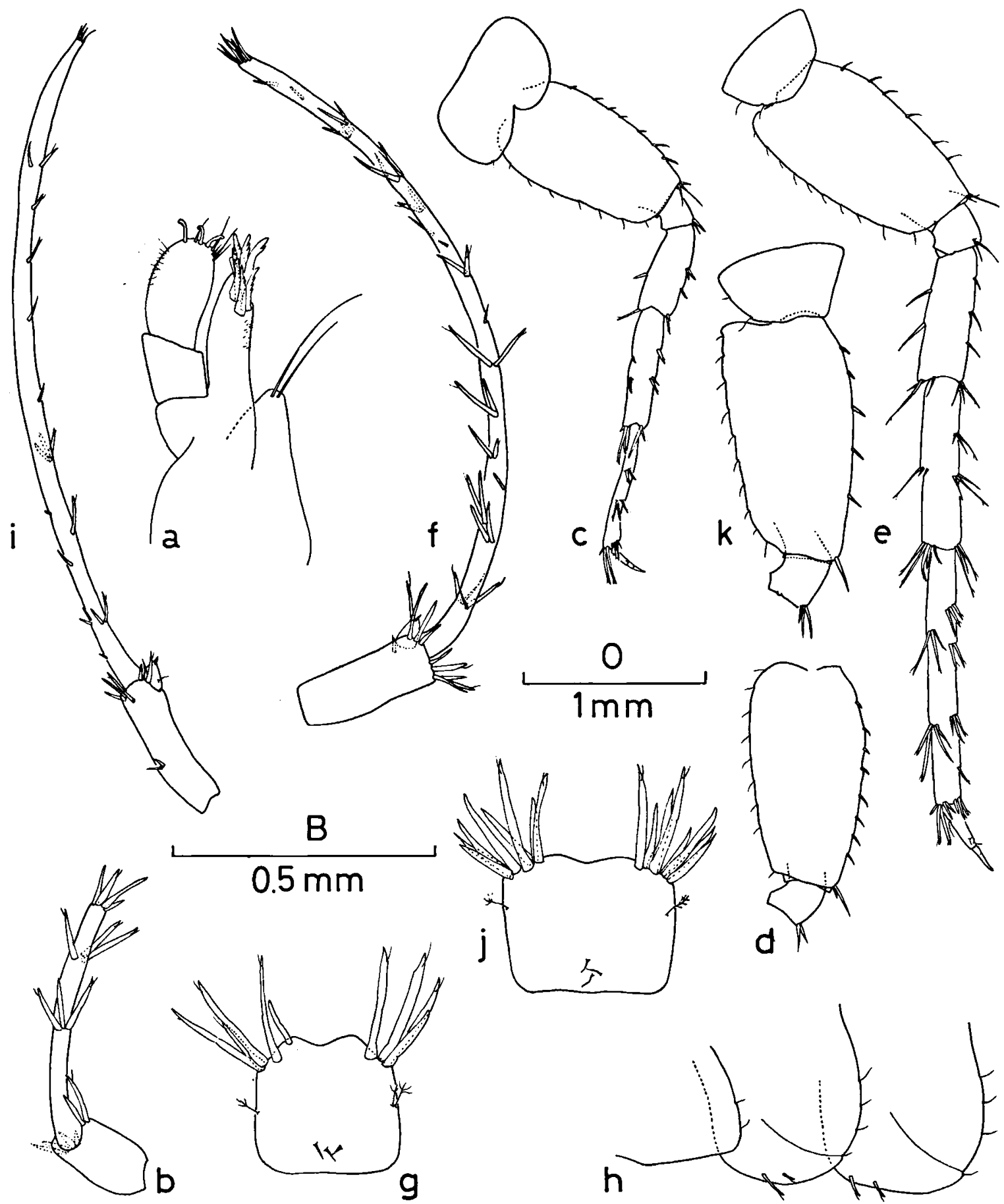

Fig. 3. Pseudoniphargus cf. branchiatus Stock, 1980 (a-b, $\$ 4.1 \mathrm{~mm}$, from Casa de la Monja near Alcoy; c-h, o $6.2 \mathrm{~mm}$, same locality; i-k, o $8.5 \mathrm{~mm}$, from Río Mundo): a, maxilla 1 (scale D); b, uropod 3 (B); c, pereiopod 5 (A); d, basis of pereiopod 6 (A); e, pereiopod 7 (A); f, uropod $3(\mathrm{O})$; g, telson (B); h, epimera (A); i, uropod 3 (A); j, telson (B); $k$, basis pereiopod 7 (A). 
shape of their posterior corners. However, because of the lack of males from the typelocality the taxonomic position of Ps. branchiatus Stock, 1980 remains uncertain.

Descriptive notes. - Based on material from Alcoy and Río Mundo classified as Ps. cf. branchiatus Stock (1980). Largest male $8.5 \mathrm{~mm}$ from Río Mundo, males from Alcoy up to 6.2 $\mathrm{mm}$. Ovigerous females ranging from 3.5 to 4.7 $\mathrm{mm}$, carrying 2-3 eggs.

Male: Antenna 1 (figs. 2a, b) $50-60 \%$ of body length, flagellum 13- to 22-segmented. Antenna 2 (fig. 2c): peduncle elongated, flagellum slightly longer than peduncle segment 5 .

Maxilla 1: outer lobe in specimens from Río Mundo with inner spine multidenticulate and other spines unidenticulate; specimens from Alcoy bearing more than one multidenticulate spine.

Gnathopod 1: coxal plate (fig. $2 \mathrm{~g}$ ) with $1+2$ distal setae, sometimes smaller than that of succeeding gnathopod; coxal plate of gnathopod 2 (fig. $2 \mathrm{~h}$ ) with $1+3$ distal setae; propodus (fig. 2d) without strongly oblique palm; spines on palmar angle not very slender, 2 smaller spines of about equal size; $8.5 \mathrm{~mm}$ large male from Río Mundo with 4 palmar angle spines (fig. 2f).

Coxae 3 and 4 (figs. 2i, j) rather wide with $1+2$ and $1+3$ distal setae, respectively; coxa 4 (fig. $2 \mathrm{j}$ ) with shallow posterior excavation. Posterior margin of propodus of pereiopods 3 and 4 (fig. 2k) with 6-8 spinules.

Pereiopods 5 to 7 (figs. 3c-e, k): basis slender, with narrow non-overhanging posterior lobe, and straight margins; claws of pereiopods 6 and 7 slender.

Epimera (fig. 3h): lower margin of plates 2 and 3 with 1-3 spines, posteroventral corner rounded, posterior margin slightly convex with about 4 setules.

Uropod 1 (fig. 2e): peduncle with 1-4 medial spines, sometimes lacking; rami not very slender, with spinose margins. Uropod 3 (figs. $3 \mathrm{i}, \mathrm{f})$ : peduncle slightly elongated, $3-4$ times as long as wide, with few small marginal spines, sometimes lacking; exopodite strongly elongated, about 22 times as long as wide, upcurved and with long (exceeding the width of exopodite) spines which are getting shorter in larger males.

Telson (figs. $3 \mathrm{~g}, \mathrm{j}$ ) subquadrate with shallow and wide distal emargination, 5-8 spines on either side.

Female: Uropod 3 (fig. 3b) peduncle 1.5-2.0 times as long as wide; exopodite not strongly elongated, about 14 times as long as wide, bearing long spines. Propodus of gnathopod 2 more elongated than in male. Remaining characters as in male; maxilla 1 shown in fig. 3a.

Variability. - Although the localities Alcoy and Río Mundo are $170 \mathrm{~km}$ apart, the specimens show only small differences. Specimens from Alcoy have, compared with those from Río Mundo, more multidenticulate spines on the outer lobe of maxilla 1, a slightly more slender propodus of male gnathopod 2 which resembles that of the female, peduncle of uropod 1 with fewer medial spines, and a more tapering telson.

\section{Pseudoniphargus nevadensis $n$. sp.}

(Figs. 4, 5j)

Material examined. - Prov. Granada, MecinaBombaron, SBR Río de Mecina, near bridge of road C332, UTM coordinates VF867938, alt. $1130 \mathrm{~m}$; 24 July 1985 (sta. A85-7/70), 1 \% holotype, 1 \% allotype, 9 ○ั $\sigma^{\circ}$ $29 \%$, and 10 juvs. (paratypes) (ZMA coll. no. Amph. 108.121).

Prov. Almería, Darrical, SBR Río de Alcolea, near bridge of the road C-332, UTM coordinates VF998903, alt. $550 \mathrm{~m}$; 23 July 1985 (sta. A85-7/67), 1 o (intersex) and 3 juvs.

Prov. Almería, Fondón, SBR Río Andarax, near bridge of road C-332, UTM coordinates WF141936, alt. $780 \mathrm{~m} ; 23$ July 1985 (sta. A85-7/68), 1 \%, 2 ९ᄋ, and 1 juv.

Prov. Granada, Cherín, SBR Río de Lucainena, near bridge of road C-332, UTM coordinates VF991913, alt. $550 \mathrm{~m}$; 24 July 1985 (sta. A85-7/69), $1 \sigma^{\circ}$ (damaged) and 2 juvs. (probably this species).

Prov. Granada, Bérchules, SBR Río Cádiar ó Guadalfeo, near bridge of road C-332, UTM coordinates VF837922, alt. $1120 \mathrm{~m}$; 24 July 1985 (sta. A85-7/71), 2 ơ $0^{\prime}, 2$ \% , and 1 juv.

Prov. Granada, Trevélez, SBR Río Trevélez, near bridge of road GR-421, UTM coordinates VF767952, alt. $1420 \mathrm{~m}$; 24 July 1985 (sta. A85-7/72), 1 and 3 juvs. 
Prov. Granada, Orjiva, SBR Río Guadalfeo, near bridge of road C-333, UTM coordinates VF631823, alt. $310 \mathrm{~m}$; 24 July 1985 (sta. A85-7/73), 2 ㅇ (1 ovigerous) and 1 juv.

Description. - Largest males $6.7 \mathrm{~mm}$; females up to $4.5 \mathrm{~mm}$. No ovigerous females present.

Male: Antenna $150-60 \%$ of body length; peduncle poorly setose, about as long as that of antenna 2, flagellum about 22-segmented, with short setae and aesthetascs 1/2-1/3 of length of corresponding segments. Antenna 2: peduncle slender, bearing long setae, segment 4 with few dorsal and distal spines; flagellum 8-segmented, about 1.5 times as long as peduncle segment 5 .

Mandible palp (fig. 4a): segment 2 as long as segment 3 , with few ventral setae; segment 3 with 1-2 A-setae, 1-2 B-setae, about $10 \mathrm{D}$-setae, and 3 E-setae. Maxilla 1: spines on outer lobe unidenticulate. Other mouthparts without peculiarities.

Gnathopod 1: coxal plate slightly longer than wide, with $1+2$ distal setae, carpus slightly shorter than propodus, palmar angle (fig. 4b) with 4 spines (one rather long). Gnathopod 2: coxal plate similar to that of gnathopod 1; carpus short; shape of propodus like branchiatus; posterior margin with 4 setal groups, palmar margin slightly convex, palmar angle (fig. 4c) with 3 spines of which 1 rather long and 1 short more interiorly implanted.

Pereiopods 3 and 4: coxal plates (figs. 4k, l) short, that of $\mathrm{P} 4$ subquadrate without posterior excavation; distal margins of plates 3 and 4 with 2-3 and 3 setae, respectively; posterior margin of propodus with about 7 spinules; dactylus as long as unguis.

Pereiopods 5 to 7 (figs. $4 d-f$ ): basis slender, posterior lobe narrow and non-overhanging, margins straight bearing rather few, short elements; distal spines on propodus not longer than claw; claw slender with unguis $1 / 2$ length of dactylus in pereiopod 6 , and about $1 / 3$ length of dactylus in pereiopod 7.

Epimera (fig. $5 \mathrm{j}$ ): ventral margin of plates 2 and 3 with $1-2$ and 2 spines, respectively; posteroventral corner pointed, posterior margin of plate 2 slightly convex, that of plate 3 straight, with 2 setules.

Uropod 1 (fig. 4g): peduncle with small basoventral spine, a row of 3 dorsal spines, 2 medial spines, and distomedial spine reaching up to half the length of endopodite; rami slender, both with one marginal spine, exopodite slightly shorter than endopodite, terminal spines slender. Uropod 2 (fig. 4h): peduncle poorly spinose, both rami with one marginal spine; exopodite slightly shorter than endopodite, terminal spines slender. Uropod 3 (fig. 4i): peduncle about 3 times longer than wide, with 1 small marginal spine, and short distal spines; exopodite strongly elongated, about 24 times as long as wide, upcurved, with several groups of 2-3 spines (in larger specimens these spines are shorter than in smaller specimens).

Telson (fig. 4j): longer than wide, somewhat tapering, with 3 subapical spines on either side, medial spines clearly longer than lateral ones.

Female: Oostegites with 7-8 setae. Uropod 3 (fig. $4 \mathrm{~m}$ ): peduncle about twice as long as wide, exopodite about 8.5 times as long as wide. Female from Río de Mecina: telson (fig. 4n) with slightly deeper distal notch. Other characters as in male.

Remarks. - The female specimens from Río Guadalfeo are characterized by very long spines on the posterior pereiopods and uropods; remaining features as in the type-specimens.

Within the branchiatus group of species, nevadensis has like $P$ s. cf. branchiatus a moderately elongated peduncle of the male uropod 3 (up to 4 times as long as wide). This in contrast with other species of this group in which the peduncle is more than 4 times as long as wide. Ps. nevadensis differs from $P$ s. cf. branchiatus in the pointed posteroventral corner of the epimera, outer lobe of maxilla 1 bearing unidenticulate spines only, and small number of terminal telson spines.

Ps. nevadensis has been found only in hyporheic habitats of a series of small parallel running rivers on the southern slopes of the Sierra Nevada, up to altitudes of $1420 \mathrm{~m}$. In the 


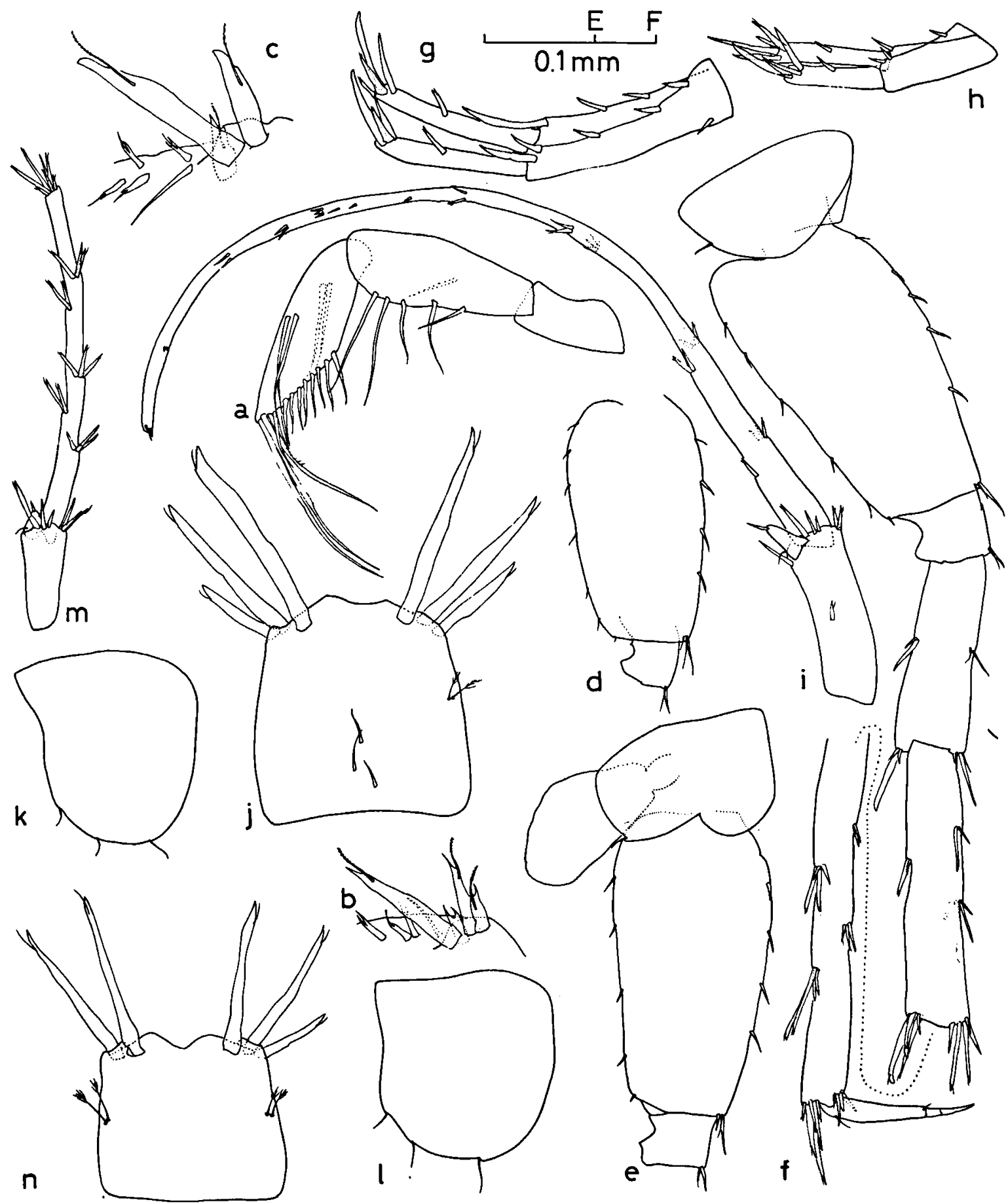

Fig. 4. Pseudoniphargus nevadensis n. sp. (a-j, $\sigma^{\circ}$ paratype $5.8 \mathrm{~mm}$; k-l, $\sigma^{\circ}$ paratype $6.7 \mathrm{~mm} ; \mathrm{m}-\mathrm{n}, \$$ paratype $4.2 \mathrm{~mm}$; all from Río Mecina): a, mandible palp (scale E); b, palmar angle gnathopod 1 (F); c, palmar angle gnathopod 2 (F); d, basis pereiopod 5 (G); e, basis pereiopod 6 (G); f, pereiopod 7 (G); g, uropod 1 (G); h, uropod 2 (G); i, uropod $3(G)$; j, telson (E); $k$, coxal plate pereiopod $3(G) ; 1$, coxal plate pereiopod $4(G)$; m, uropod $3(G)$; $n$, telson (E). 
same kind of habitat north of this mountain ridge around the city of Granada another species of Pseudoniphargus has been found, granadensis. Ps. nevadensis is rather similar to the latter, but differs in the elongation of the peduncle of the male uropod 3 , unequal length of the rami of uropods 1 and 2, shape and armature of the telson, and shape of the epimera.

Etymology. - The proposed specific name nevadensis alludes to the Sierra Nevada, at the southern slopes of which this species was found.

\section{Pseudoniphargus granadensis n. sp.} (Figs. 5-6)

Material examined. - Prov. Granada, Granada, SBR Río Genil near Cenes de la Vega, about $6 \mathrm{~km}$ E.S.E. of Granada, UTM coordinates VG527125, alt. $750 \mathrm{~m} ; 17$ July 1985 (sta. A85-7/52), 1 o holotype, 1 ovigerous $\&$ allotype, 6 ơ 42 우 (3 ovigerous), and 16 juvs. (paratypes) (ZMA coll. no. Amph. 108.118).

Prov. Granada, Dúdar, SBR Río Aguas Blancas, about $8.5 \mathrm{~km}$ E. of Granada, UTM coordinates VG564155, alt. $800 \mathrm{~m} ; 17$ July 1985 (sta. A85-7/53), 2 damaged specimens and 1 juv.

Prov. Granada, Granada, SBR Río Darro, near Molino de la Higuera, about $2 \mathrm{~km}$ E. of Granada, UTM coordinates VG497153, alt. 750 m; 18 July 1985 (sta. A85-7/54), 3 o' $0^{\circ}, 4$ \& $\%$, and 3 juvs.

Description. - Largest male and female 6.8 $\mathrm{mm}$; ovigerous females ranging from 3.3 to 5.0 $\mathrm{mm}$.

Male: Antenna $160-70 \%$ of body length; peduncle similar to nevadensis; flagellum about 25-segmented, distal segments (fig. 5a) slender, aesthetascs about $1 / 2$ of length of corresponding segments, those on distal segments about as long as these segments. Antenna 2 as in nevadensis.

Mandible palp (fig. 5b): segment 3 with 1 Aseta, 1-3 B-setae, 13-17 D-setae, and 3-4 Esetae, otherwise as in nevadensis. Maxilla 1: spines on outer lobe (fig. 6a) multidenticulate. Maxillipedal palp, particularly its claw, slender. Other mouthparts without peculiarities.

Gnathopod 1 (fig. 6b): coxal plate wider than in nevadensis, with 2 long distal setae; carpus slightly longer than propodus; propodus with 7 palmar angle spines. Gnathopod 2: coxal plate similar to that of gnathopod 1; propodus (fig. $6 c$ ) of about the same shape as in nevadensis, but with S-shaped palmar margin; palmar angle spines robust, not very slender.

Pereiopods 3 and 4: coxal plate 3 (fig. 5c) slender, plate 4 (fig. $5 \mathrm{~d}$ ) with shallow posterior excavation; distal margin of plates 3 and 4 with 2 and 3 setae, respectively; posterior margin of propodus with about 8 spinules, unguis slightly shorter than dactylus.

Pereiopods 5 to 7: as in nevadensis, but with more elements on basal margins; anterior margin of basis of pereiopods 5 and 6 (figs. 5e, f) with some 7 spinules, that of pereiopod 7 (fig. $5 \mathrm{~g}$ ) with 5 spinules; posterior margin of basis of pereiopod 5 with about 8 setules, that of pereiopods 6 and 7 with 10 setules.

Epimera (fig. 5i): lower margin of plates 2 and 3 with 2-3 spines, posteroventral corner rounded, not pointed; posterior margin convex with 2-4 setules.

Uropod 1 (fig. 6d): peduncle with 1-2 small basoventral spines, a row of 6 dorsal spines, 3 medial spines, and distomedial spine reaching up to half the length of endopodite; rami of equal length, both with 1 marginal spine, terminal spines slender. Uropod 2 (fig. 6e): peduncle with some dorsal spines and 2 distal spines on both sides; rami of equal length with 2-3 spines on the margins. Uropod 3 (fig. 6f): peduncle about 4-5 times longer than wide, with several marginal spines; exopodite elongated, about 18 times longer than wide, upcurved, with groups of 1-3 spines, which are shorter (in smaller specimens slightly longer) than the width of the exopodite.

Telson (fig. 5h) with convex margins, about as long as wide, tapering, distal emargination shallow and wide, with 1 apical spine and a subapical group of 6-7 spines on either side. Smaller specimens (fig. $6 \mathrm{~g}$ ) without terminal spines, and weakly developed subterminal group of spines.

Female: Oostegites with 7-9 setae. Uropod 3 (fig. 6h): peduncle about 2 times as long as 


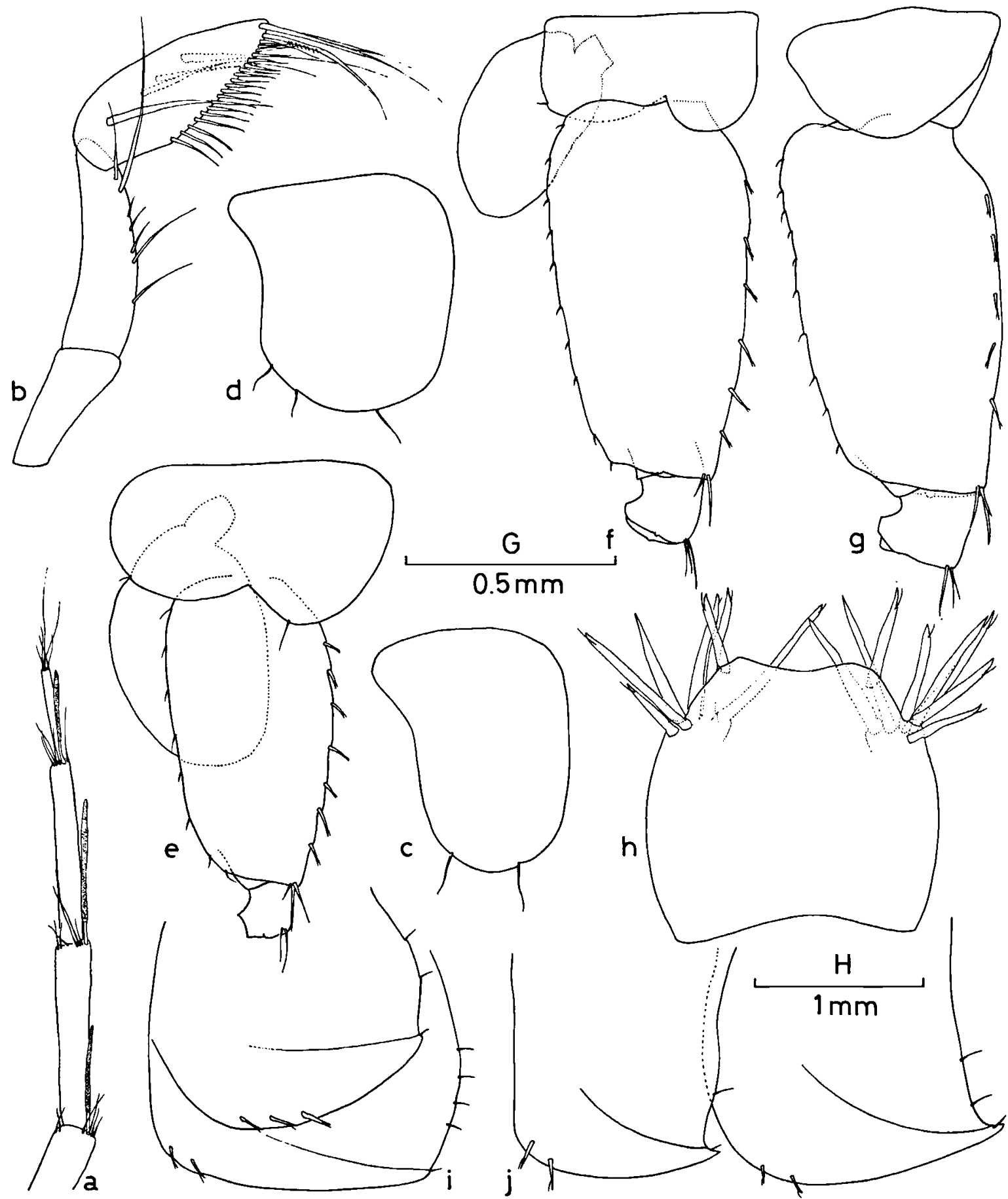

Fig. 5 a-i, Pseudoniphargus granadensis n. sp., o holotype $6.8 \mathrm{~mm}$, from Río Genil: a, distal part of antenna 1 (scale E); b, mandible palp (E); c, coxal plate pereiopod $3(\mathrm{G})$; d, coxal plate pereiopod $4(\mathrm{G})$; e, basis pereiopod $5(\mathrm{G})$; f, basis pereiopod $6(\mathrm{G}) ; \mathrm{g}$, basis pereiopod $7(\mathrm{G})$; h, telson (E); i, epimeral plates 2 and $3(\mathrm{G})$.

j, Pseudoniphargus nevadensis n. sp., O paratype $6.7 \mathrm{~mm}$, from Río Mecina: epimeral plates 2 and $3(\mathrm{H})$. 

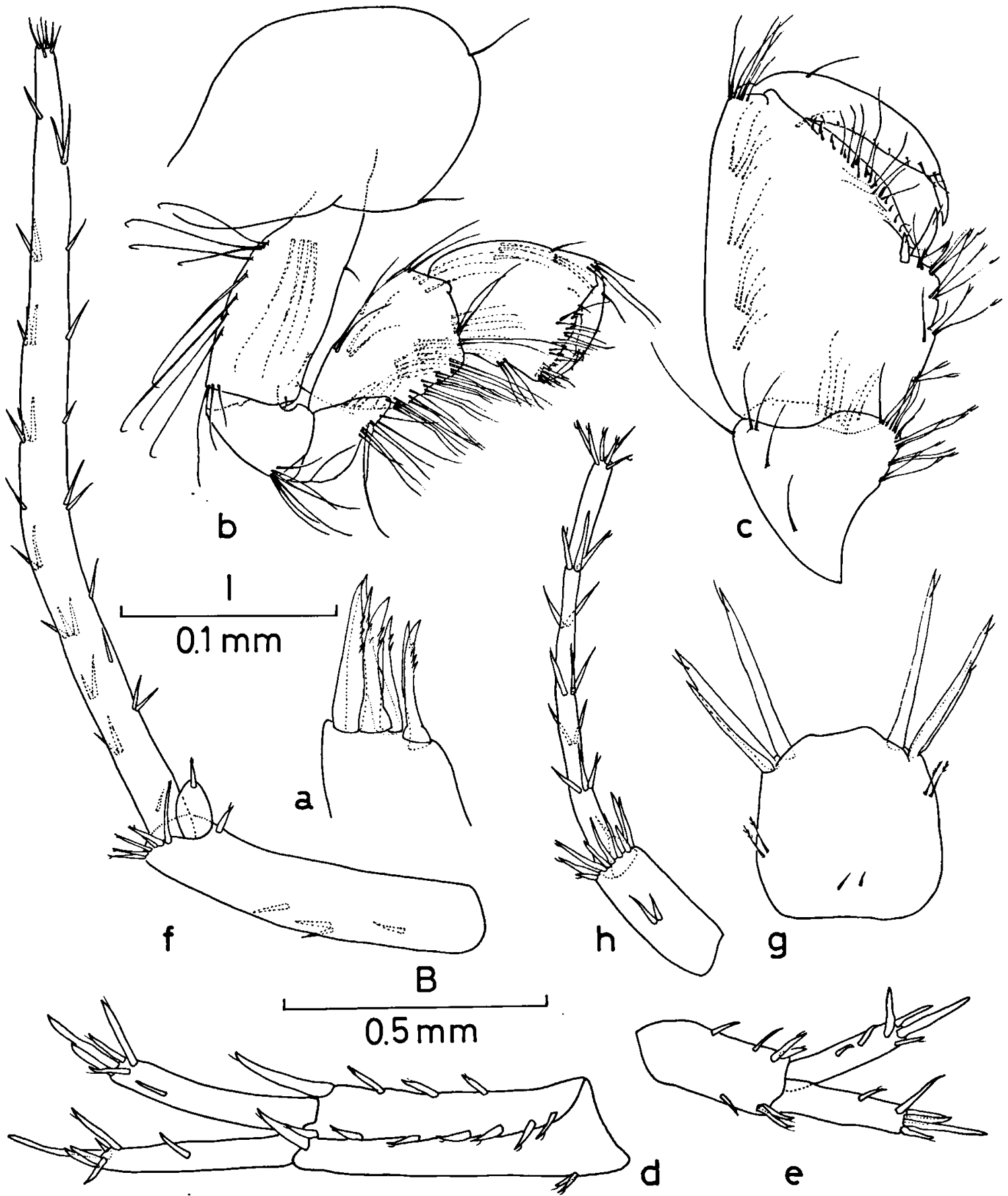

Fig. 6. Pseudoniphargus granadensis n. sp. (a-f, ơ holotype $6.8 \mathrm{~mm}$; , ơ paratype $3.4 \mathrm{~mm}$; h, 9 paratype $4.7 \mathrm{~mm}$; all from Río Genil): a, outer lobe maxilla 1 (scale I); b, gnathopod 1 (B); c, distal part of gnathopod 2 (B); d, uropod 1 (B); e, uropod 2 (B); f, uropod 3 (B); g, telson (D); h, uropod 3 (B). 
wide, with 2 marginal and many long distal spines, exopodite about 14 times longer than wide, provided with many rather long spines. Remaining characters as in male.

Remarks. - Within the branchiatus group this species is mainly characterized by the shape and armature of the telson.

North of Granada another species of Pseudoniphargus was found in the Manantial de Deifontes. This species is probably classified with grandis and differs from granadensis apart from the telson, in the shape of coxae 1 to 4 and rather short claws of pereiopods 6 and 7 .

Etymology. - The trivial name granadensis proposed for this species alludes to the town of Granada in the surroundings of which this species was found.

\section{Pseudoniphargus grandis $\mathrm{n}$. sp.}

(Figs. 7-10)

Material examined. - Prov. Málaga, Arenas, well just E. of road C-335 from Vélez-Málaga to Alhama de Granada, $1.5 \mathrm{~km} \mathrm{~S}$. of Los Vados, UTM coordinates UF999764, alt. $80 \mathrm{~m}$; 30 July 1984 (sta. 84-7/39), 1 \% holotype, $1 \%$ allotype, $1 \%, 7 \%$, and 31 specimens (paratypes) (ZMA coll. no. Amph. 108.125); 15 July 1985 (sta. A85-7/44), $2 \sigma^{\circ} \sigma^{\circ}, 2$ ovigerous $\$ Q$, and 41 specimens (paratypes) (ZMA coll. no. Amph. 108.126).

Prov. Málaga, Vélez-Málaga, well just E. of road C$335,0.8 \mathrm{~km} \mathrm{~S}$. of Trapiche, UTM coordinates UF9973, alt. $50 \mathrm{~m}$; 30 July 1984 (sta. 84-7/38), 5 ơ ovigerous), and 11 juvs. (paratypes) (ZMA coll. no. Amph. 108.129).

Prov. Málaga, Viñuela, SBR Río Vélez, $2 \mathrm{~km}$ S.S.E. of Viñuela, UTM coordinates UF992786, alt. $100 \mathrm{~m} ; 30$ July 1984 (sta. 84-7/40), 3 ○ீ $^{\circ}, 3$ \% , and more than 100 specimens (paratypes) (ZMA coll. no. Amph. 108.124).

Prov. Málaga, well at Cortijo El Moral, N. of Río Guadalmedina, $2 \mathrm{~km}$ E. of Casarbermeja, UTM coordinates UF7484, alt. 700 m; 30 July 1984 (sta. 84-7/37), $4 \% Q$ and 1 juv.

Prov. Málaga, well S. of Río Guadalmedina, $2.5 \mathrm{~km} \mathrm{E.}$ of Casarbermeja, UTM coordinates UF7684, alt. $700 \mathrm{~m}$; 30 July 1984 (sta. 84-7/35), 4 juvs. (probably this species).

Prov. Málaga, SBR Río de la Cueva, Ríogordo, UTM coordinates UF846866, alt. 370 m; 12 July 1985 (sta. A857/32), 8 o $0^{\circ}, 5$ 우, and about 20 juvs.

Prov. Málaga, Cueva de la Fajara, Canillas de Aceituna, UTM coordinates VF024825, alt. $520 \mathrm{~m} ; 14$ July 1985 (sta. A85-7/42), 3 우 (1 ovigerous).

Prov. Málaga, Fuente de la Fajara (karst spring), Canillas de Aceituna, UTM coordinates VF024825, alt.
$500 \mathrm{~m} ; 14$ July 1985 (sta. A85-7/43), 3 juvs. (probably this species).

Prov. Málaga, well at Torrox-Costa, Torrox, UTM coordinates VF158656, alt. 5 m; 15 July 1985 (sta. A857/45), 1 damaged $\sigma^{\circ}$ (contamination of sample A85-7/44 ?).

Prov. Granada, Illora, SBR in large spring at Allomartes (Manantial de Allomartes), UTM coordinates VG1925, alt. $600 \mathrm{~m}$; 1 Aug. 1984 (sta. 84-8/1), 7 juvs. (probably this species).

Prov. Granada, SBR at large spring in Deifontes (Manantial de Deifontes), UTM coordinates VG4732, alt. $580 \mathrm{~m}$; 1 Aug. 1984 (sta. 84-8/2), 4 Ơ 2 juvs. (probably this species).

Description. - Largest male and female (ovigerous) both from Los Vados, 11.5 and 7.2 $\mathrm{mm}$, respectively. Females carrying up to 5 eggs. Largest male and female from Río Vélez 6.7 and $5.5 \mathrm{~mm}$, respectively.

Male: Antenna $160-80 \%$ of body length; peduncle poorly setose; flagellum 20 - to 25 segmented, aesthetascs 1/4-1/3 of length of corresponding segments, that on penultimate segment longer. Antenna 2: peduncle slender, as long as that of A1, poorly setose, segment 4 with several short dorsal and ventral spines, and longer distal spines; flagellum 7- to 9segmented, 1.5 times as long as peduncle segment 5 (smaller specimens with longer antennal setation).

Mandible palp (fig. 7a): segment 2 with ventral setae and a row of longer distoventral setae, segment 3 with $1 \mathrm{~A}$-seta, 3 B-setae, 15-20 Dsetae, and 3-4 E-setae. Maxilla 1: outer lobe (fig. 7b) with multidenticulate spines, 1 inner spine bearing 1-2 denticles. Other mouthparts without peculiarities.

Gnathopod 1: coxal plate wide with 4 distal setae (3 short); carpus as long as propodus. Gnathopod 2 (fig. 8a): coxal plate as that of gnathopod 1; carpus short; propodus with strongly oblique and slightly S-shaped palmar margin, palmar angle spines in specimens from Río Vélez more slender (fig. 8f); unguis $1 / 4$ of length of dactylus.

Pereiopods 3 (fig. 8b) and 4: coxal plate 3 rather wide, distal margin with 3-4 setules, plate 4 (fig. 8c) subquadrate, with shallow posterior excavation; propodus with about 6 


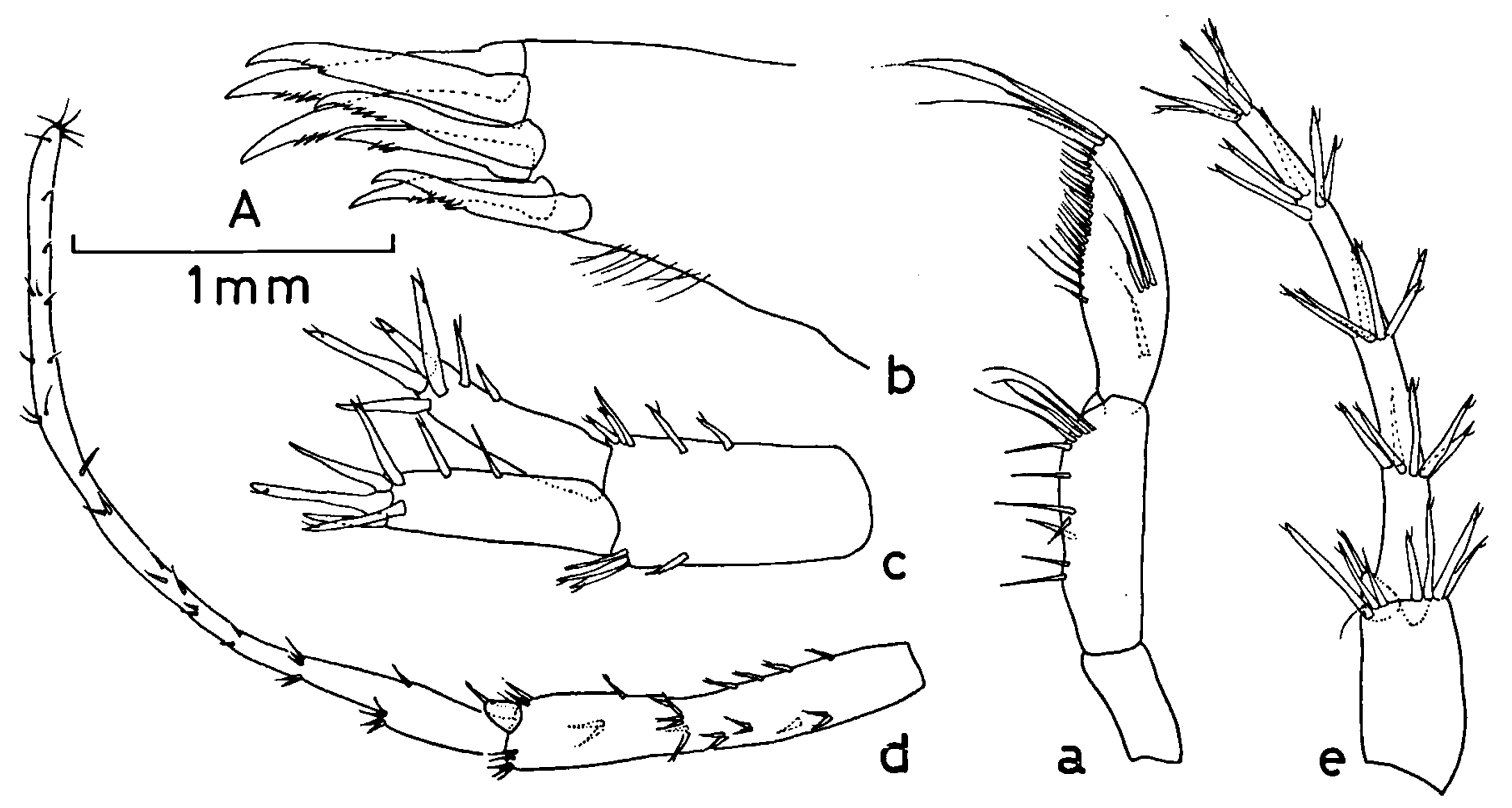

Fig. 7. Pseudoniphargus grandis n. sp. (a-d, $\sigma^{\circ}$ paratype $11.5 \mathrm{~mm}$, from Los Vados; e, $\$ 6.0 \mathrm{~mm}$, from Manantial de Deifontes): a, mandible palp (scale B); b, outer lobe maxilla 1 (I); c, uropod 2 (B); d, uropod 3 (A); e, uropod 3 (B).

spinules on posterior margin; unguis as long as dactylus.

Pereiopods 5 to 7 (figs. 9a-c): basis slender with weakly developed non-overhanging posterior lobe, anterior margin with about 7 rather short spinules, posterior margin with some 12 (P5 and P6) or about 14 (P7) rather short setules; distal segments with many spines which are getting shorter when the animal becomes larger; distal propodal spines slightly shorter than dactylus; claw not very slender, unguis about half of length of dactylus.

Epimera (fig. 8e): plates with rounded ventral margin bearing $2-3$ short spines; posteroventral corner rounded; posterior margin convex with few setules.

Uropod 1 (fig. 8d): peduncle with 1-2 basoventral spines, a row of 4-5 dorsal spines, a variable (0-3) number of medial spines, and a long distomedial spine reaching up to or beyond half the length of endopodite; rami marginally poorly spinous, with slender terminal spines. Uropod 2 (fig. 7c): peduncle with several slender dorsal spines, and 2-3 distal spines on either side; rami marginally spinous. Uropod 3 (fig. 7d): peduncle about 6 times as long as wide with many, rather long marginal spines; exopodite strongly elongated, about 23 times as long as wide, upcurved, with many groups of 1-3 slender spines.

Telson (fig. 10a): about as long as wide, with straight lateral margins, terminal lobes flattened, distal notch narrow, of varying depth, each lobe with a row of 6-8 slender terminal spines.

Female: Oostegites with 10-13 setae. Uropod 3 (fig. 7e): peduncle 2-3 times as long as wide, slightly longer than the telson, sometimes with 1 marginal group of spines; exopodite about 11 times as long as wide, 3 groups of 2-3 long spines on either margin, terminal spines as long as marginal spines. Other characters similar to male; telson as illustrated (fig. 8g).

Remarks. - This species has been found in different biotopes northeast of Málaga and in hyporheic habitats of two large springs at Deifontes and Allomartes, north and northwest of the town of Granada, respectively. Specimens from the latter locality were all small and are only provisionally classified with this species. Specimens from Deifontes, compared 


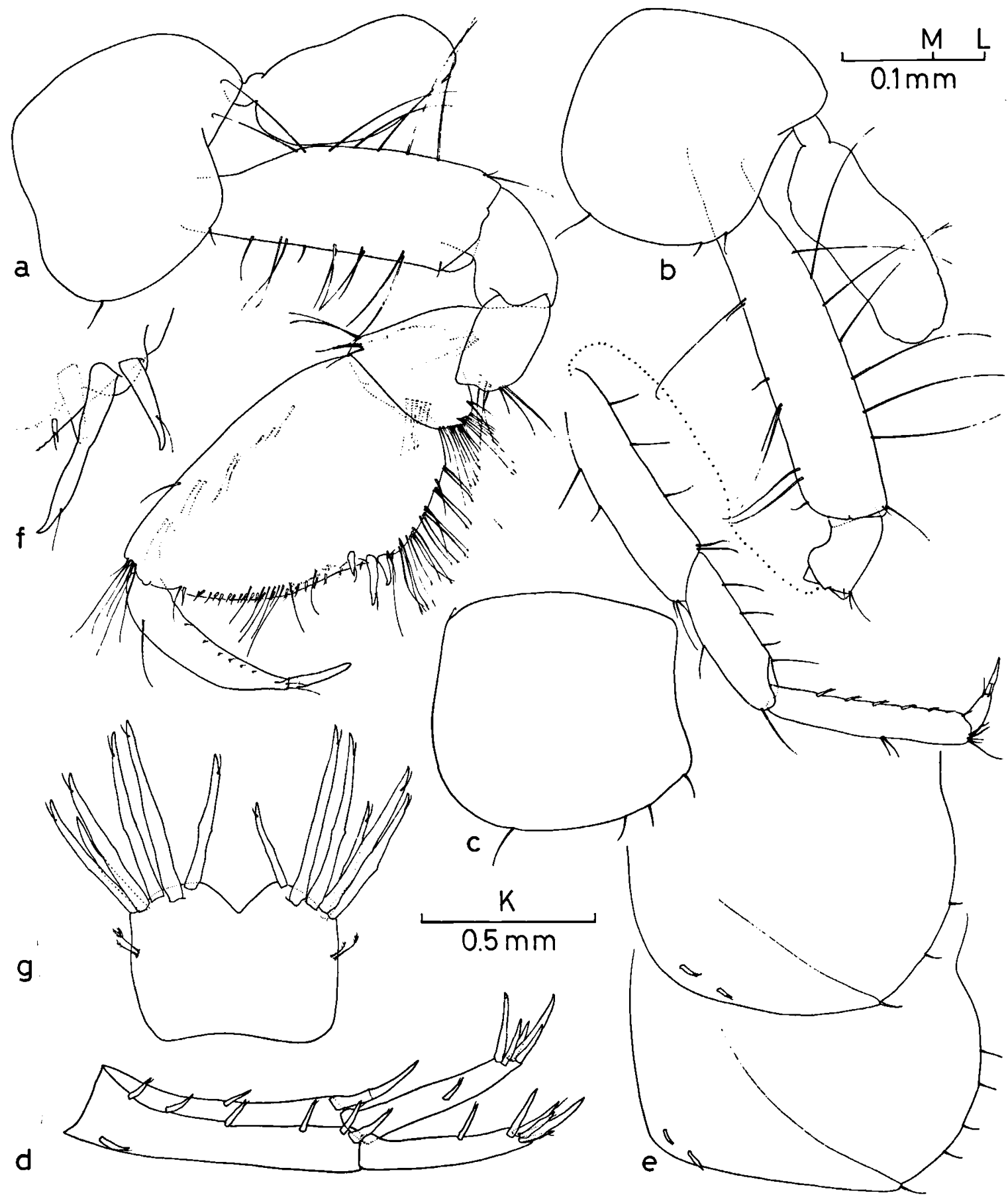

Fig. 8. Pseudoniphargus grandis n. sp. (a-e, o’ paratype $11.5 \mathrm{~mm}$, from Los Vados; f, ơ paratype $6.7 \mathrm{~mm}$, from Río Vélez; g, $\%$ paratype $7.2 \mathrm{~mm}$, from Los Vados): a, gnathopod 2 (scale K); b, pereiopod $3(\mathrm{~K})$; c, coxal plate pereiopod 4 (K); d, uropod $1(\mathrm{~K})$; e, epimeral plates 2 and $3(\mathrm{~K})$; f, palmar angle gnathopod 2 (L); $\mathrm{g}$, telson (M). 


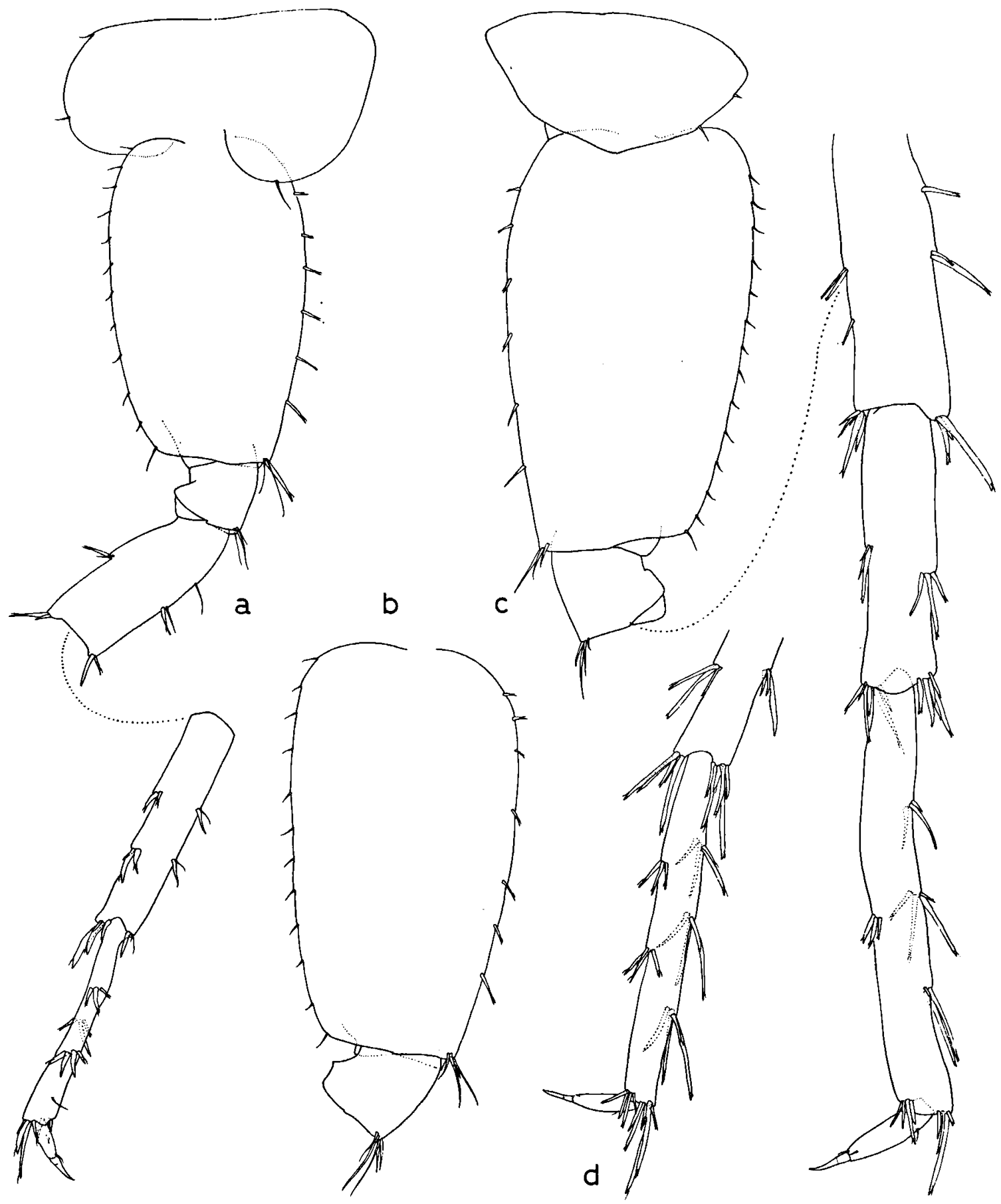

Fig. 9. Pseudoniphargus grandis $\mathrm{n}$. sp. (a-c, o paratype $11.5 \mathrm{~mm}$, from Los Vados; d, \& paratype $6.7 \mathrm{~mm}$, from Río Vélez): a, pereiopod 5 (scale K); b, basis pereiopod $6(\mathrm{~K})$; c, pereiopod $7(\mathrm{~K})$; d, distal part pereiopod $7(\mathrm{~K})$. 


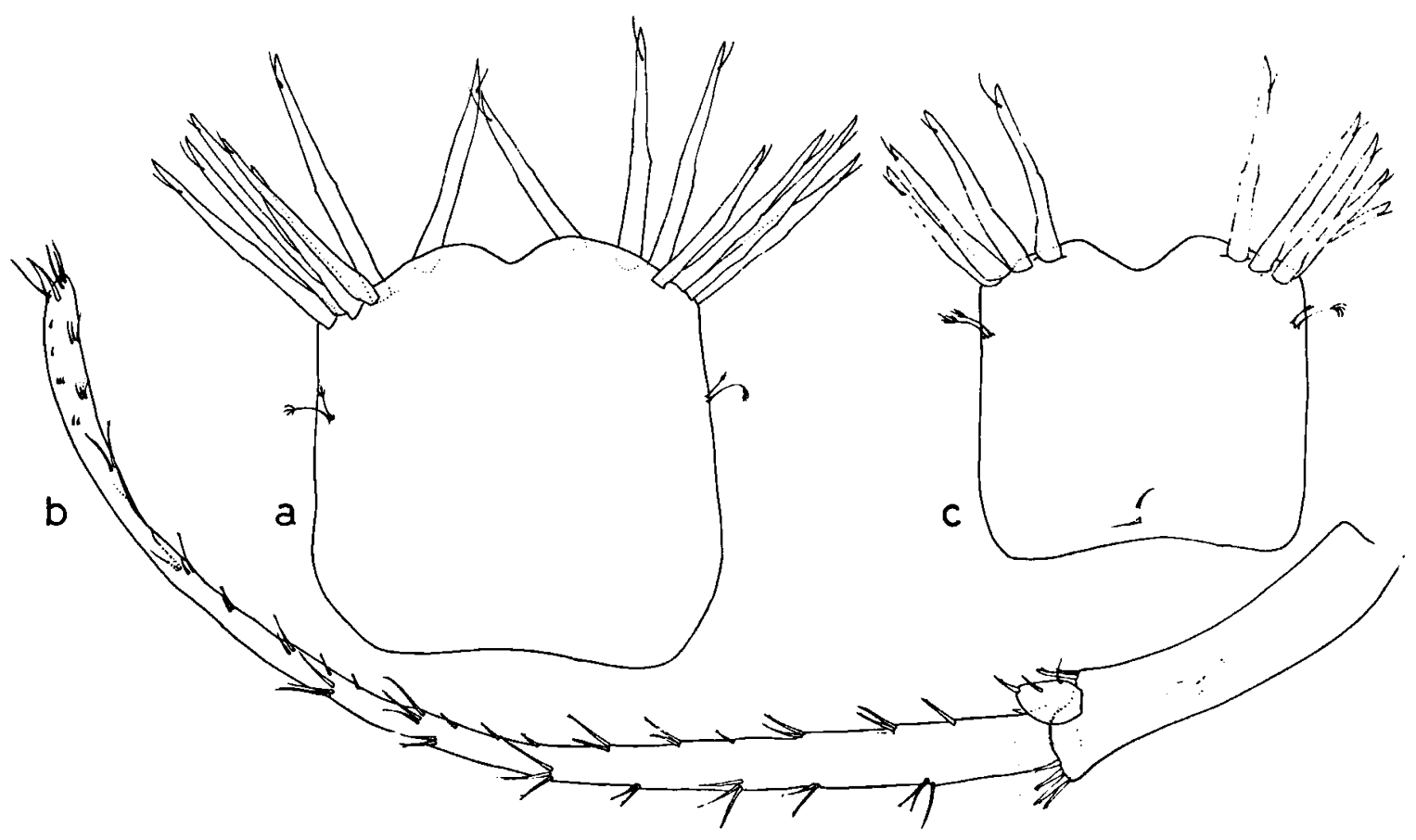

Fig. 10. Pseudoniphargus grandis n. sp. (a, o* paratype $11.5 \mathrm{~mm}$, from Los Vados; b-c, O $^{\circ} 8.0 \mathrm{~mm}$, from Deifontes): a, telson (scale $\mathrm{M}$ ); b, uropod $3(\mathrm{~K})$; c, telson (M).

with the types, have a less elongated peduncle of uropod 3 (fig. 10b), bearing in males fewer and in females (fig. 7e) no marginal spines. However, in many other characters (telson (fig. 10c), coxae, uropods 1 and 2, and mandible palp) they resemble the type-specimens.

Specimens from the underflow of Río Vélez are in general smaller than specimens originating from wells in the same valley (Trapiche and Los Vados). Moreover, these riverine specimens bear longer setae on antenna 2, and longer spines on the posterior pereiopods (fig. 9d) and exopodite of uropod 3. However, smaller specimens from the wells also have these setae and spines longer than the largest animals from the same population.

This species reaches lengths up to $11.5 \mathrm{~mm}$ and is one of the largest species of the genus Pseudoniphargus. Within the branchiatus group it is characterized by the flattened terminal lobes of the telson bearing a row of strong spines, and by its wide coxae 1 to 4 .

Etymology. - The proposed specific name grandis alludes to the relatively large size of this species.

\section{Pseudoniphargus affinis $\mathrm{n}$. sp.}

(Figs. 11-12)

Material examined. - Prov. Granada, pool in artificial gallery near the rise of the Río Frio, $8 \mathrm{~km}$ upstream of Ríofrio, UTM coordinates UG9006, alt. 700 m; 31 July 1984 (sta. 84-7/42), 1 o holotype, 1 ovigerous ○ allotype, $150^{\circ} \circ, 64$ ९ (29 ovigerous), 45 juvs., and 35 unsexed specimens (paratypes) (ZMA coll. no. Amph. 108.127).

Prov. Granada, Loja, Fuente La Carmonilla (karst spring), UTM coordinates UG991137, alt. $520 \mathrm{~m}$; 19 July 1985 (sta. A85-7/85), 2 ơ 6 , 6 ९ \&, 2 damaged specimens, and 2 juvs. (probably this species).

Description. - Largest male $8.5 \mathrm{~mm}$; ovigerous females ranging from 3.8 to $6.5 \mathrm{~mm}$, carrying 1 to 3 eggs.

Male: Antenna 1 about half as long as body; peduncle about as long as that of antenna 2, poorly setose; flagellum 15- to 18-segmented, aesthetascs half the length of corresponding segments. Antenna 2: peduncle segment 4 
bearing slender spines; flagellum 7-segmented, 1.5 times as long as peduncle segment 5 .

Mandible palp (fig. $11 \mathrm{~g}$ ) very slender, segment 2 with ventral and some long distoventral setae, segment 3 with 2 A-setae, 1 B-seta, 15 Dsetae, and $3 \mathrm{E}$-setae. Outer lobe of maxilla 1 (fig. $11 \mathrm{~h}$ ) with 4 multidenticulate spines. Maxillipedal palp (fig. 11i) and its claw slender. Remaining mouthparts without peculiarities.

Gnathopod 1: coxal plate with 1-2 rather long distal setae; carpus as long as propodus. Gnathopod 2: coxal plate (fig. 11c) like that of gnathopod 1; carpus short; propodus (fig. 11a) with oblique, S-shaped palmar margin (fig. $11 \mathrm{~b}$ ), palmar angle spines robust; unguis about $1 / 3$ of dactylus.

Pereiopods 3 and 4 (fig. 12b): coxal plate 3 (fig. 12a) rather short with 2-3 long distal setae, plate 4 subquadrate with 4-5 long distal setae and posterior margin hardly excavate; posterior margin of propodus with 7-8 slender spinules; unguis as long as dactylus.

Pereiopods 5 to 7 (figs. 12c-e): basis with narrow non-overhanging posterior lobe; basis of pereiopod 5 (fig. 12c) subrectangular, margins convex with some 5 anterior spinules, and about 7 posterior setules; basis of succeeding pereiopods more tapering (figs. 12d, e), with about 6 spinules on anterior and some 10 setules on posterior margin; unguis in pereiopod 5 (fig. 12c) about as long, in pereiopod 7 (fig. 12e) about half as long as dactylus; distal propodal spines not longer than dactylus.

Epimera (fig. 12g): ventral margin of plates 2 and 3 slightly convex, with about 2 spines; posteroventral corner rectangular with small tooth; posterior margin straight with few setules.

Uropod 1 (fig. 11d): peduncle with small basoventral spine, a row of 4 dorsal spines, medial spines lacking and distomedial spine reaching up to half the length of endopodite; each ramus with 0-1 marginal spine. Uropod 2 (fig. 11e): peduncle with 2 medial spines, and 2 distal spines on either side; rami short, with 1-2 marginal spines. Uropod 3 (fig. 12f): peduncle 7.5-9.5 times as long as wide, with 4-5 groups of 1-4 spines; exopodite elongated, about 25 times as long as wide, upcurved, margins with many groups of 1-4 slender spines.

Telson (fig. 11f) slightly wider than long, with straight lateral margins, distal emargination shallow, and 3 or 4 subterminal spines on either side.

Female: Oostegites with about 10 setae. Carpus of gnathopod 2 slightly longer than in male. Uropod 3 (fig. 11j): peduncle twice as long as wide, with one marginal spine; exopodite about 15 times as long as wide, 3-4 groups of 2-3 long spines on either side, terminal spines as long as marginal spines. Remaining characters as in male.

Remarks. - Both records of this species are from habitats related to karst springs west and north of the Sierra Gorda complex. This sierra, consisting of the Sierra de Loja and Sierra de Alhama, is composed of extensively karstified limestones. It can be divided in a northern and a southern hydrographic basin (Moreno Calvillo \& Castillo Martin, 1982). The localities of affinis have connections with this northern basin. Another locality in this area, the underflow of the Arroyo del Salar, revealed Pseudoniphargus as well; however, these specimens probably belong to another species, i.e., Ps. cf. fragilis.

Males from Fuente La Carmonilla are rather small, probably subadult, lacking an elongate uropod 3, and therefore difficult to compare with males from the type-locality. Females from La Carmonilla are conform with affinis, except for a more slender carpus and propodus of gnathopod 2, slightly narrower coxae 3 and 4, a more strongly developed posterodistal corner of the basis of the posterior pereiopods and absence of marginal armature on the peduncle of uropod 3. Because these variations might be considered intraspecific, the material from La Carmonilla is classified, with reservations, with affinis.

Ps. affinis is closely related to stocki and grandis; all have the peduncle of uropod 3 of the male more than 4 times as long as wide, and a telson with straight lateral margins. Ps. affinis 


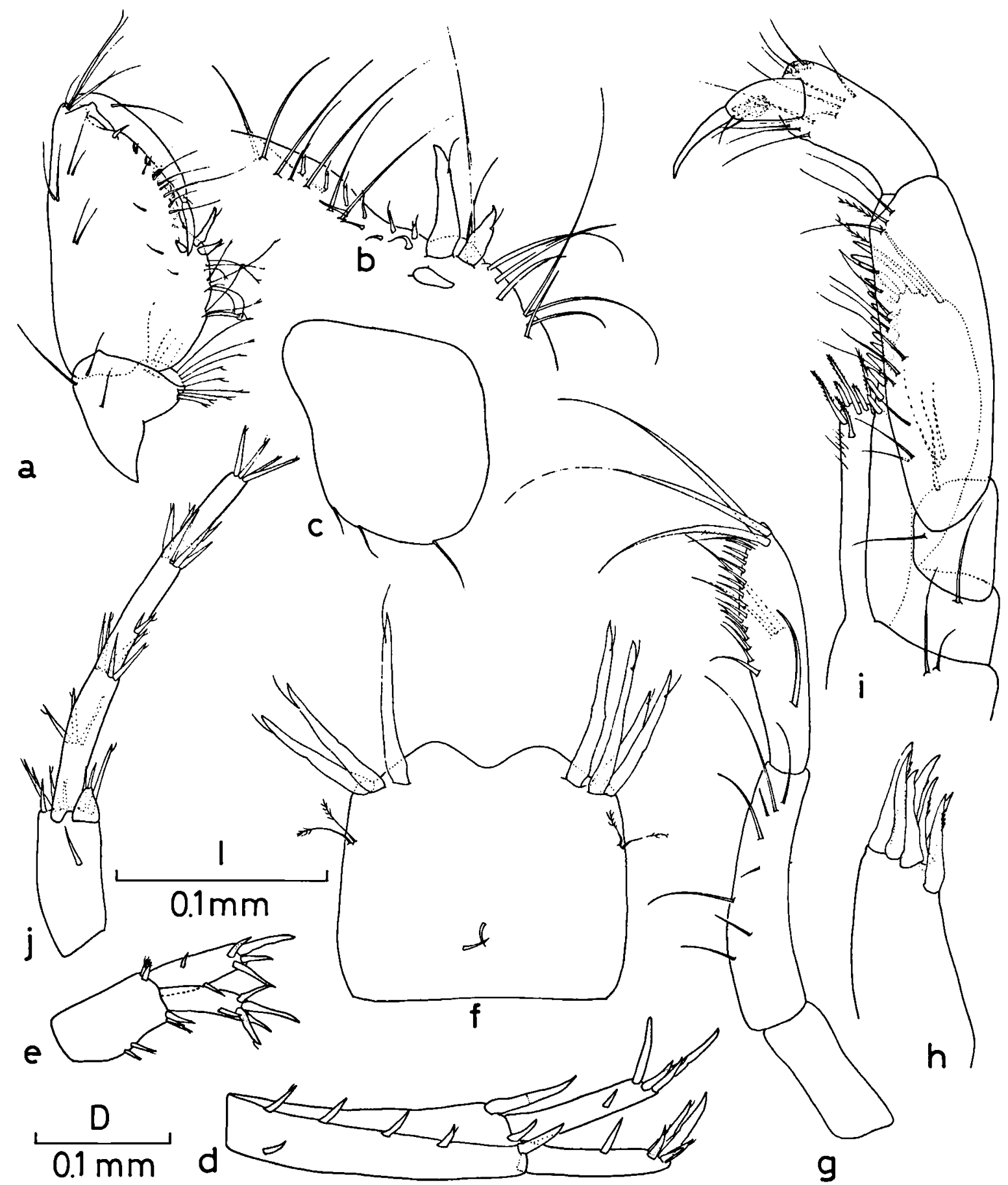

Fig. 11. Pseudoniphargus affinis n. sp. (a-f, o* paratype $7.0 \mathrm{~mm} ; \mathrm{g}-\mathrm{i}, \mathrm{O}^{\circ}$ paratype $6.7 \mathrm{~mm}$; j, ovigerous $\$$ paratype 6.5 $\mathrm{mm}$; all from Río Frio): a, distal part gnathopod 2 (scale B); b, palmar margin gnathopod 2 (D); c, coxal plate gnathopod 2 (B); d, uropod 1 (B); e, uropod 2 (B); f, telson (D); g, mandible palp (D); h, outer lobe maxilla 1 (I); $\mathrm{i}$, maxilliped (D); j, uropod 3 (B). 


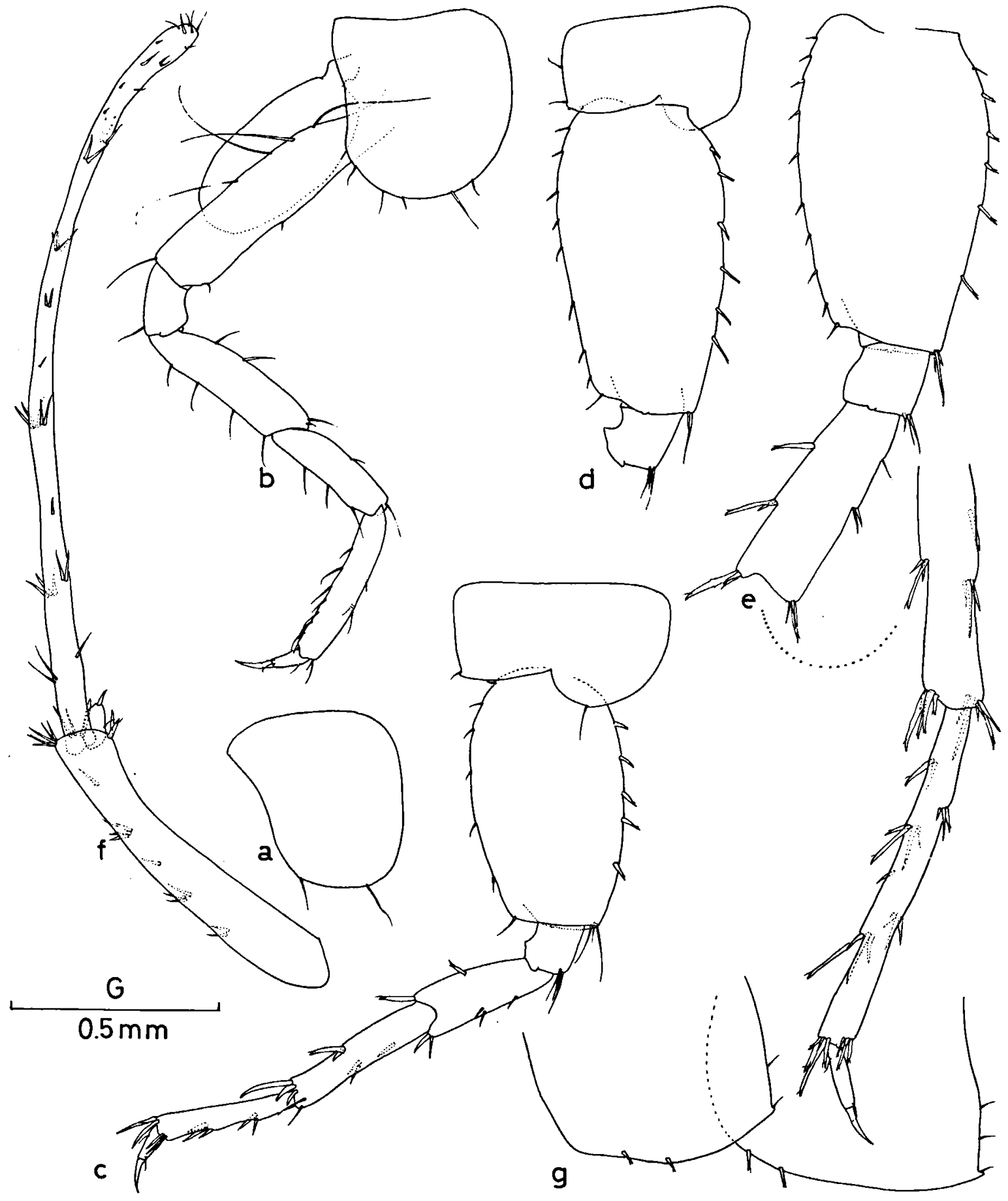

Fig. 12. Pseudoniphargus affinis $\mathrm{n}$. sp. (a-f, $\sigma^{\circ}$ paratype $7.0 \mathrm{~mm}$; $\mathrm{g}$, o paratype $6.7 \mathrm{~mm}$; both from Río Frio): a, coxal plate pereiopod 3 (scale G); b, pereiopod $4(G)$; c, pereiopod $5(G)$; d, basis pereiopod $6(G)$; e, pereiopod 7 (G); f, uropod $3(G) ; g$, epimeral plates 2 and $3(G)$. 
differs from stocki mainly in shorter setae on antenna 2, 7 spines on the outer lobe of maxilla 1 , wider propodus of gnathopod 2, and epimera with a rectangular posteroventral corner and straight posterior margin. Most important differences of affinis as compared to grandis are the longer aesthetascs on the flagellum of antenna 1 , the more slender palp of mandible and maxilliped, fewer multidenticulate spines on the outer lobe of maxilla 1 , the rectangular posteroventral corner and straight posterior margin of the epimera, and fewer spines on the telson. Apart from the telson, affinis differs from granadensis in the shape of coxae 3 and 4 , armature of uropods 1 and 2, and shape of the epimera.

Etymology. - The name affinis is proposed for this species because of its close relationships to Ps. stocki and grandis.

\section{Pseudoniphargus stocki n. sp.}

(Figs. 13-14)

Pseudoniphargus branchiatus Stock, 1980 pro parte (from Hundidero-Gato cave system).

Material examined. - Prov. Málaga, cave system of Hundidero-Gato near Benaoján, UTM coordinates UF0067, alt. $423 \mathrm{~m}$; 31 July 1978, 1 \% holotype, 1 ovigerous $q$ allotype, $1 \sigma^{\circ}$ and $6 \%$ (paratypes), leg. Biospeleologische Werkgroep (ZMA coll. no. Amph. 107.384); 25 July 1984 (sta. 84-7/23), 1 \& paratype (ZMA coll. no. Amph. 108.123).

Prov. Málaga, well near bridge of the Río Guadiaro along local road Benaoján-Ronda, $\mathrm{N}$. of the river, $\mathrm{E}$. of the road ( $2 \mathrm{~km} \mathrm{~W}$. of Ronda), UTM coordinates UF0268, alt. $300 \mathrm{~m}$; 26 July 1984 (sta. 84-7/25), 1 small $\sigma^{\circ}$ and 1 small $\&$ (probably this species).

Prov. Cádiz, well E. of road C-3331 from Grazalema to Ubrique, $1.5 \mathrm{~km} \mathrm{~S}$. of the bifurcation with road C-344 Grazalema-Ronda (15 km W. of Ronda), UTM coordinates TF9169, alt. 770 m; 28 July 1984 (sta. 84-7/30), 2 १ ( 1 ovigerous) and 1 juv.

Prov. Cádiz, well S. of road C-3331 GrazalemaUbrique, $0.2 \mathrm{~km} \mathrm{S.W}$. of Villaluenga del Rosario, UTM coordinates TF864636, alt. 860 m; 28 July 1984 (sta. 847/31), 1 juv. (probably this species).

Prov. Cádiz, well N. of road C-3331 from Grazalema to Ubrique, $3.5 \mathrm{~km}$ from Ubrique $(25 \mathrm{~km} \mathrm{W.S.W.} \mathrm{of}$ Ronda), UTM coordinates TF8164, alt. $480 \mathrm{~m} ; 28$ July 1984 (sta. 84-7/32), 4 small $\$ Q$ and 5 juvs. (probably this species).
Description. - Largest two males both 4.5 $\mathrm{mm}$, largest female (ovigerous) $6.0 \mathrm{~mm}$.

Male: Antenna 1 similar to affinis. Antenna 2 with long setae; peduncle segment 4 with long spines; flagellum 7-segmented, 1.5-2.0 times as long as peduncle segment 5 .

Mandible palp: segment 2 with few ventral setae, segment 3 somewhat shorter as segment 2 with 1 A-seta, 1-2 B-setae, 11 D-setae, and 3 E-setae. Maxilla 1: outer lobe (fig. 13e) with 8 slender, smooth or unidenticulate spines. Maxillipedal palp and other mouthparts as in affinis.

Gnathopod 1 as in affinis. Gnathopod 2: propodus (fig. 13f) rather slender, with slightly oblique, convex palmar margin, palmar angle spines slender, otherwise as in affinis.

Pereiopods 3 to 7 similar to those of affinis.

Epimera (fig. 14g): plates with 1-2 spines on ventral margin, posteroventral corner rounded, posterior margin slightly convex with few setules.

Uropod 1: peduncle as in affinis; endopodite slightly longer as exopodite, each without marginal spines, terminal spines slender. Uropod 2 as in affinis. Uropod 3 (fig. 13g): peduncle about 6.5 times as long as wide, with several marginal spines; exopodite elongate, about 20 times as long as wide, slightly upcurved, margins with many groups of 1-3 slender spines.

Telson: slightly longer than wide; distal notch shallow, rather wide; with 4 long subapical spines on either side.

Female: Oostegites with about 12 setae. Gnathopod 2 (fig. 13c): carpus longer than in male, shape of propodus similar to that of male. Pereiopods 5 to 7 (figs. 14a-c): elements on margins of basis longer than in male, one of the females from Gato with submarginal setules on posterodistal part of basis of pereiopod 5 (fig. 14a), these are lacking in the other females. Rami of uropod 1 (fig. 14d) longer than in male. Uropod 3 (fig. 14e): peduncle 2.5 times as long as wide, with 1 group of marginal spines; exopodite about 9 times as long as wide, each margin with 2-3 groups of 2-3 spines, terminal spines as long as marginal spines. 


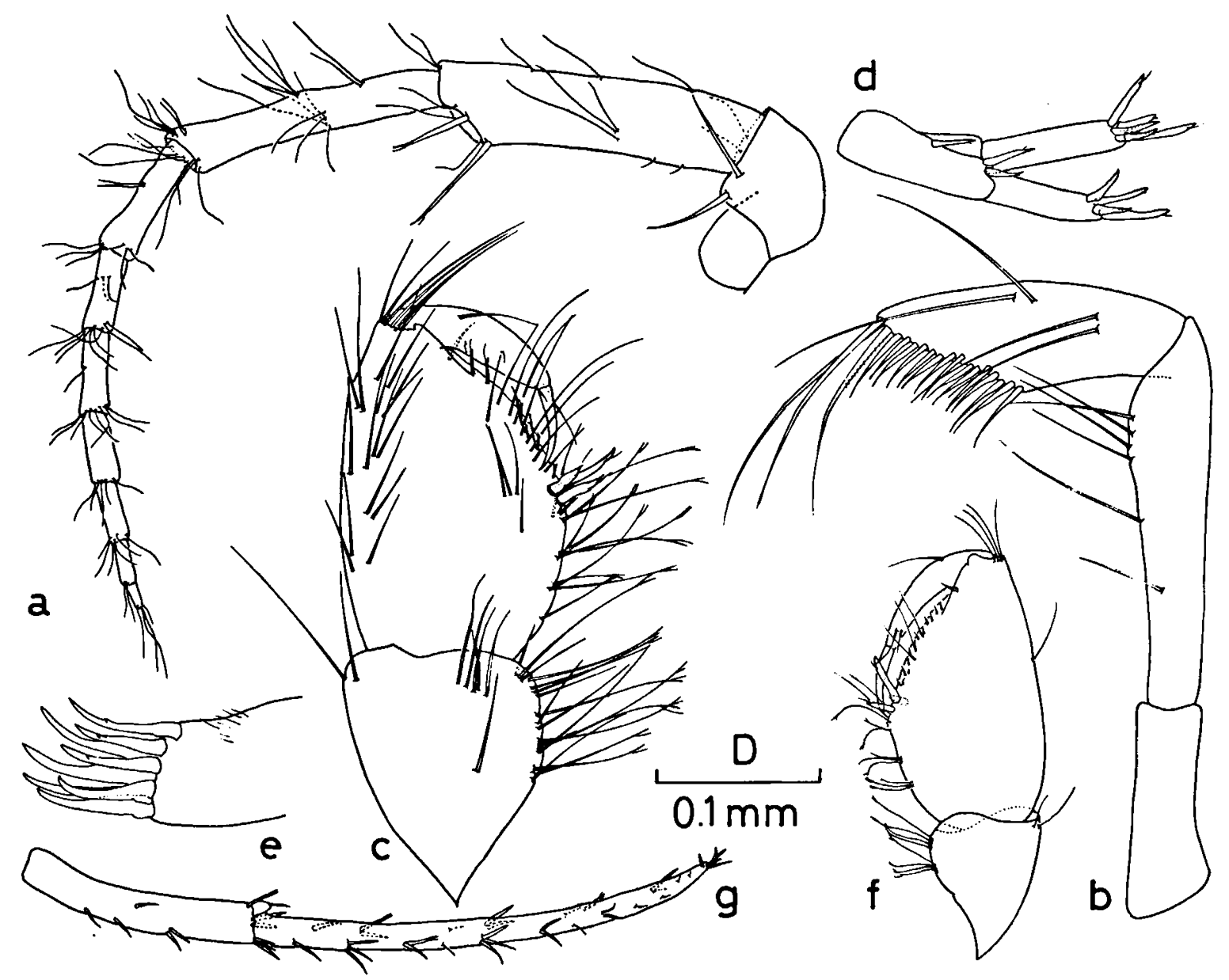

Fig. 13. Pseudoniphargus stocki n. sp. (a-d, ovigerous $\&$ paratype $6.0 \mathrm{~mm}$; e-g, $\sigma$ paratype $4.5 \mathrm{~mm}$; both from Gato resurgence): a, antenna 2 (scale B); b, mandible palp (D); c, distal part gnathopod 2 (B); d, uropod 2 (B); e, outer lobe maxilla 1 (I); f, distal part gnathopod 2 (B); g, uropod 3 (A).

Remaining characters as in male; antenna 2 (fig. 13a), mandible palp (fig. 13b), uropod 2 (fig. 13d) and epimera (fig. 14f) are additionally figured.

Remarks. - The specimens from Hundidero-Gato were previously designated by Stock (1980) as paratypes of branchiatus (see the remarks under the latter species). During this study we found some material of Pseudoniphargus in wells in the surroundings of the HundideroGato cave system (west of Ronda) most of which is doubtfully classified with stocki.

Remarkable is the maxilla 1 in this species which bears 8 spines on its outer lobe. Furthermore the species is characterized in respect to the other species of the branchiatus group by the slender propodus of gnathopod 2, long setae of antenna 2 , and poorly spinose uropod 2 .

Etymology. - This species is dedicated to Prof. Dr. J. H. Stock, in recognition of his basic contribution to the taxonomic knowledge of the genus Pseudoniphargus, which has served as a starting point for the present study of the Spanish species of this genus.

\section{Pseudoniphargus vomeratus $n$. sp.}

(Figs. 15-17)

Material examined. - Prov. Jaén, caught spring, probably nonkarstic, just $S$. of the road J-701 from Siles to Cotillas, $1 \mathrm{~km} \mathrm{N.E.} \mathrm{of} \mathrm{Siles,} \mathrm{UTM} \mathrm{coordinates}$ 


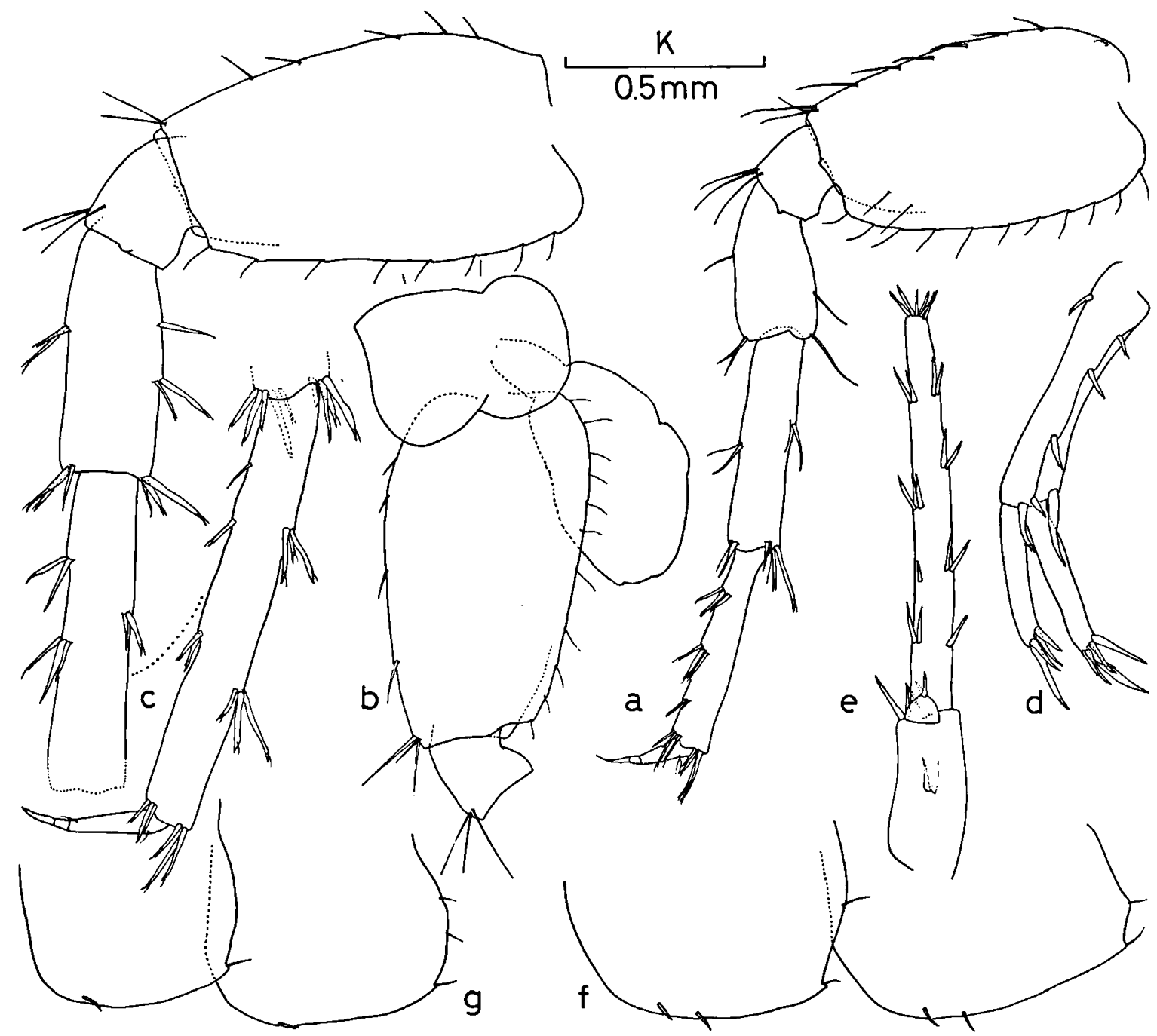

Fig. 14. Pseudoniphargus stocki n. sp. (a-f, ovigerous $\$$ paratype $6.0 \mathrm{~mm} ; \mathrm{g}$, $\sigma$ paratype $4.5 \mathrm{~mm}$; both from Gato resurgence): a, pereiopod 5 (scale $\mathrm{K})$; b, basis pereiopod $6(\mathrm{~K})$; c, pereiopod $7(\mathrm{~K})$; d, uropod $1(\mathrm{~K})$; e, uropod $3(\mathrm{~K})$; f, epimeral plates 2 and $3(\mathrm{~K}) ; \mathrm{g}$, epimeral plates 2 and $3(\mathrm{~K})$.

WH3750, alt. $820 \mathrm{~m}$; 25 Jan. 1984 (sta. 84-1/9), 1 o" holotype, $1 \odot$ allotype, $40^{\circ} O^{\circ}, 3 \% \odot$, and 2 juvs. (paratypes) (ZMA coll. no. Amph. 108.122).

Description. - Largest male and female 10.0 and $6.7 \mathrm{~mm}$, respectively; only ovigerous female $6.0 \mathrm{~mm}$, carrying 3 eggs.

Male (fig. 15): Antenna $170-80 \%$ of body length; peduncle as long as that of antenna 2, poorly setose; flagellum 25- to 27-segmented with short setae, aesthetascs about $1 / 3$ of length of corresponding segments. Antenna 2: pedun- cle segment 4 with several spines; flagellum of 11 segments, about 2 times as long as peduncle segment 5 , bearing short setae.

Mandible palp (fig. 16a): segment 2 with few ventral and distoventral setae; segment 3 with 1 A-seta, 4 B-setae (one shorter), $15 \mathrm{D}$-setae and 4 E-setae. Outer lobe of maxilla 1 with 7 rather long spines, 3 of which multidenticulate and the others smooth or unidenticulate $(10 \mathrm{~mm}$ large male bearing left 7 and right 8 spines). Other mouthparts without peculiarities.

Gnathopod 1: coxal plate (fig. 17c) rather 


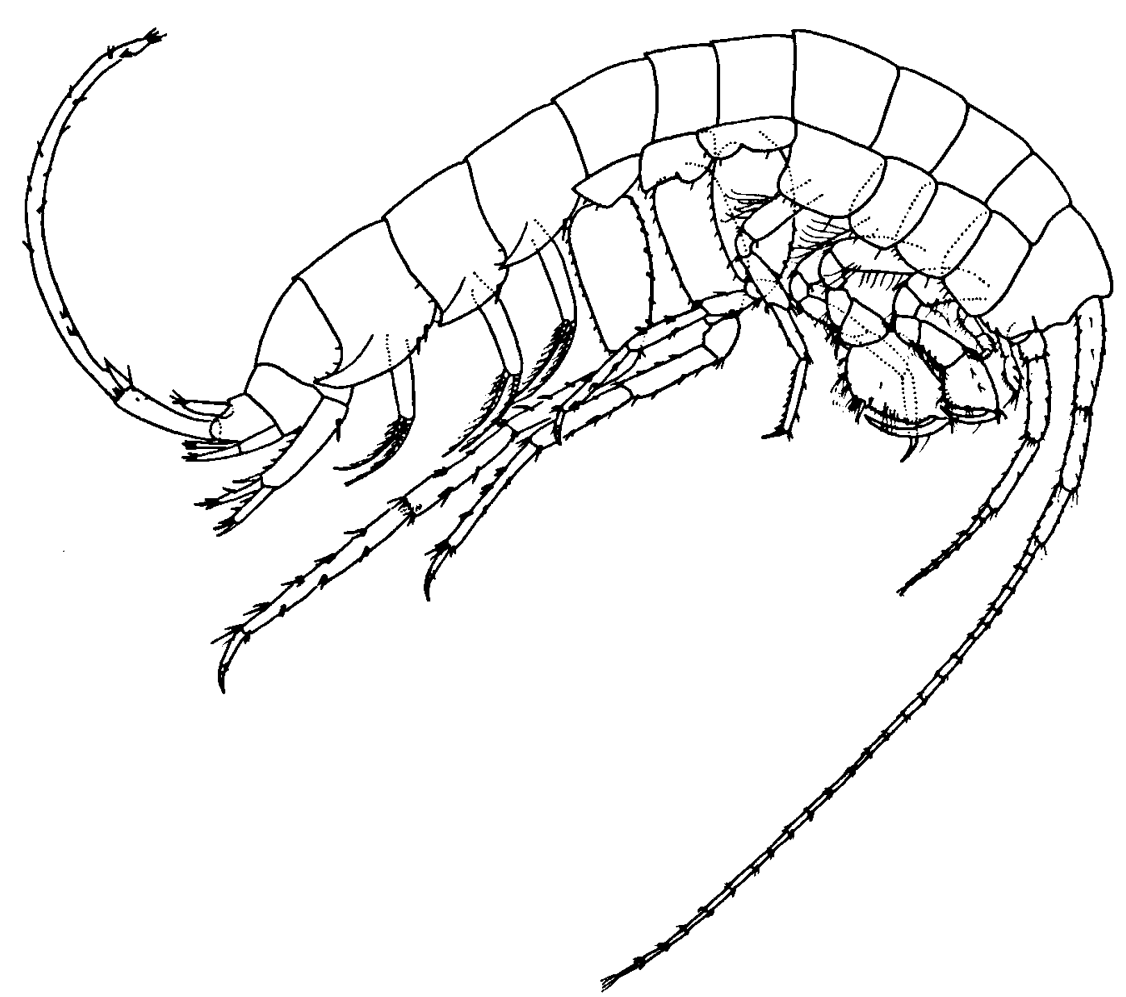

Fig. 15. Pseudoniphargus vomeratus n. sp., $\sigma^{\circ}$ paratype $10.0 \mathrm{~mm}$, from Siles.

wide, lower margin with 4 short and 1 longer setae; carpus as long as propodus, palmar angle with 5 spines ( 3 longer and 2 smaller), unguis about half as long as dactylus. Gnathopod 2 (fig. 17a): coxal plate similar to that of gnathopod 1; carpus short; propodus (fig. 17b) wide with 5 setal groups on posterior margin, palmar margin slightly oblique; unguis $1 / 3-1 / 4$ of length of dactylus.

Pereiopods 3 and 4: coxal plate 3 (fig. 17d) resembling that of gnathopod 2, plate 4 wider, posterior margin hardly excavate; propodus with about 12 elements (spinules and setules) on posterior margin; unguis as long as dactylus.

Pereiopods 5 to 7: basis (fig. 17e) slender, in larger males somewhat tapering, posterior lobe narrow, non-overhanging. Anterior margin of basis with 4 (P5), 9 (P6), and 5 (P7) spinules, posterior margin with 12 setules; each spine group on distal segments consisting of few spines, which are short in pereiopod 5 and are gradually getting longer in succeeding pereiopods; claw short, unguis 1/3-1/4 of length of dactylus.

Epimera (fig. 16d): plates 1 and 2 with slightly convex ventral margin, each with 1 spine; that of plate 3 rather straight with 2 spines; posteroventral corners strongly produced; posterior margin rather straight, with few setules.

Uropod 1: peduncle slender with weak basoventral spine, dorsal row of 8 spines, 1 or 2 medial spines, and distomedial spine reaching up to $1 / 3$ of endopodite; rami rather short, both with some marginal armature, terminal spines short. Uropod 2: peduncle with 2-3 dorsal spines, and 2 distal spines on either side; rami with few marginal spines. Uropod 3 (fig. 16b): peduncle elongate, 5-5.5 times as long as wide, with 2 small marginal spines and few distal 


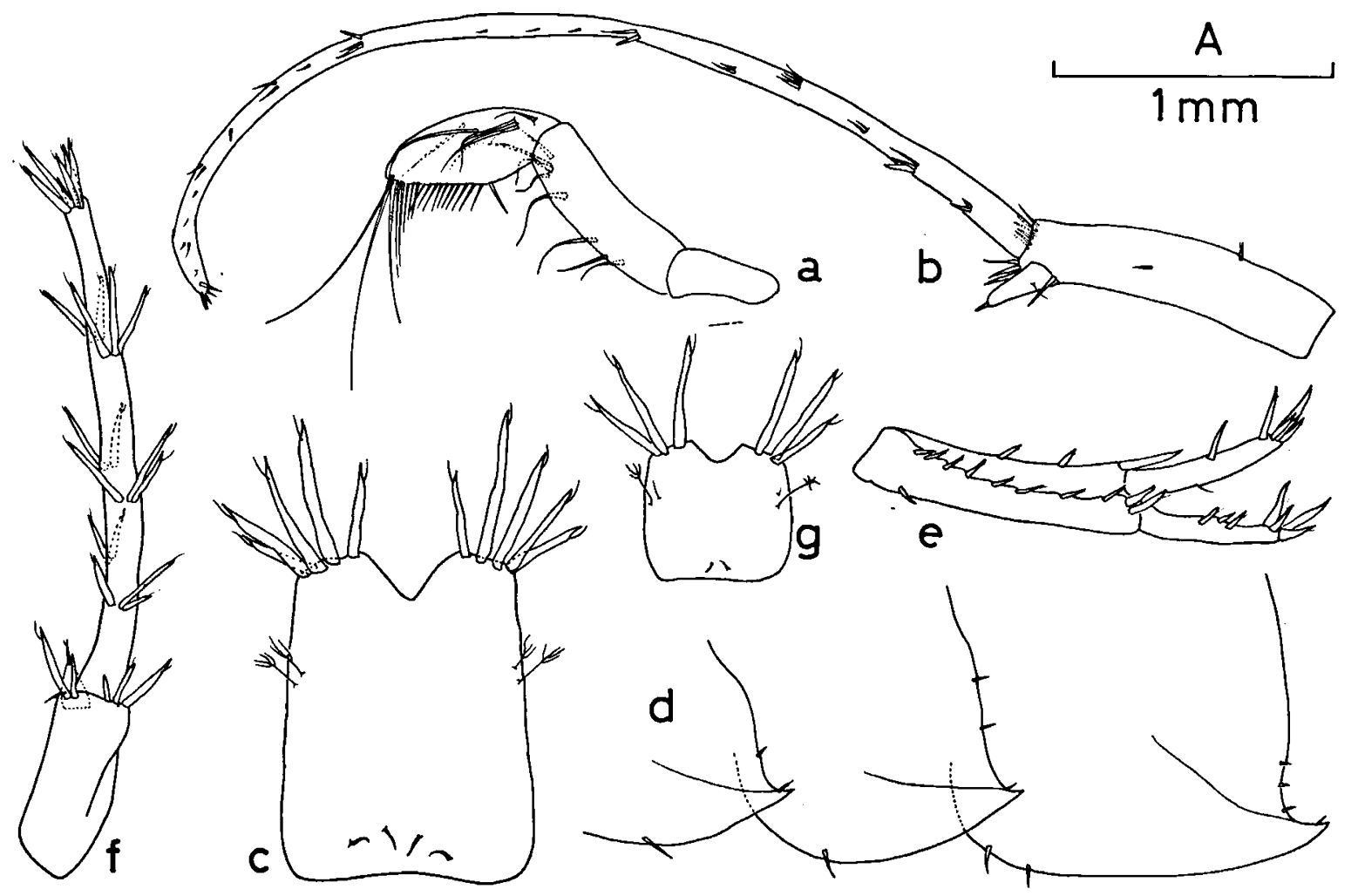

Fig. 16. Pseudoniphargus vomeratus n. sp. (a-d, ơ paratype $10.0 \mathrm{~mm}$; e-g, ovigerous $\$$ paratype $6.0 \mathrm{~mm}$; both from Siles) a, mandible palp (scale B); b, uropod 3 (A); c, telson (B); d, epimera (A); e, uropod 1 (A); f, uropod 3 (A); g, telson (B)

spines; endopodite rather slender with short distal spine; exopodite strongly elongate, about 29 times as long as wide and upcurved.

Telson (fig. 16c) about 1.5 times as long as wide, somewhat tapering, lateral margins straight; distal notch V-shaped, rather deep with 5 spines on either side.

Female: Antenna 1 shorter than in male, about half as long as body; flagellum 16- to 18segmented. Propodus of gnathopod 2 more slender than that of male. Oostegites with 8-9 setae. Uropod 3 (fig. 16f): peduncle 2-2.5 times as long as wide; exopodite about 12.5 times as long as wide, with 3 spine groups on either margin, each group of 2-3 long spines, terminal spines as long as marginal spines. Telson (fig. $16 \mathrm{~g}$ ): wider than long, much shorter than that of male, distal emargination more U-shaped than in male, with 3-4 spines on either side. Remaining characters as in male; additionally illustrated are: uropod 1 (fig. 16e), and pereiopods 4,5 , and 7 (figs. $17 \mathrm{f}-\mathrm{h}$ ).

Remarks. - The only known locality of this species, on the northern slopes of the Sierra de Segura, is situated within the range of latipes. Ps. cf. branchiatus from the Río Mundo was also found in this vicinity. However, vomeratus does not show close affinities to either of these, and is well defined within the genus. The telson in the male resembles that of macrotelsonis Stock (1980) from northern Algeria, and slightly that of illustris. Re-examination of the types of macrotelsonis elucidated that the telson in this species is sexually dimorphous as well, though provided with a lower number of terminal spines as in vomeratus. Other features of vomeratus shared by illustris and macrotelsonis are the elongated peduncle and exopodite of the male uropod 3, and the strongly produced 


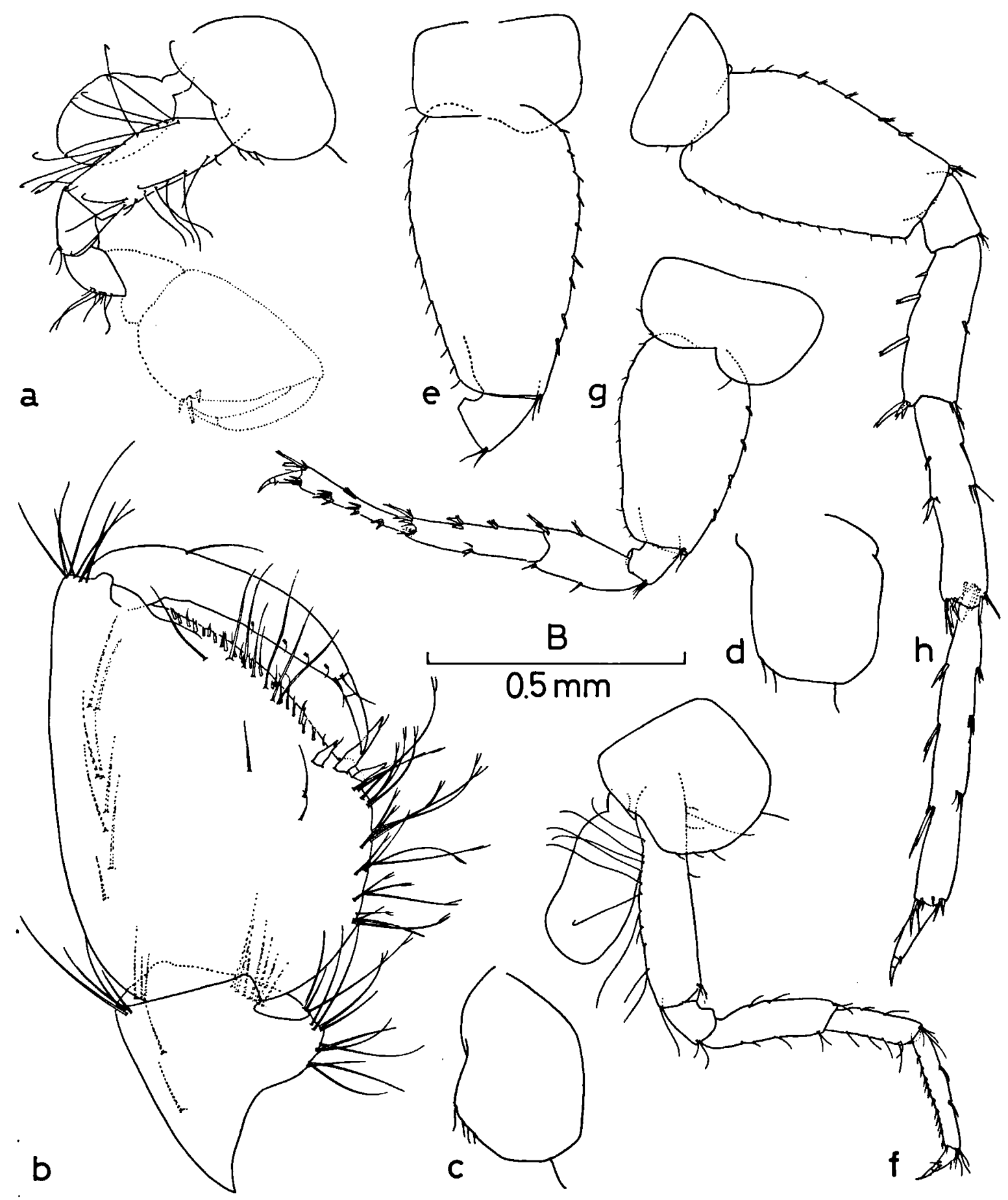

Fig. 17. Pseudoniphargus vomeratus $\mathrm{n}$. sp. (a-e, $\sigma^{\circ}$ paratype $10.0 \mathrm{~mm}$; $\mathrm{f}$, ovigerous $\$$ paratype $6.0 \mathrm{~mm}$; both from Siles): a, gnathopod 2 (scale A); b, distal part gnathopod 2 (B); c, coxal plate gnathopod 1 (A); d, coxal plate pereiopod 3 (A); e, basis pereiopod 6 (A); f, pereiopod 4 (A); g, pereiopod 5 (A); h, pereiopod 7 (A). 
posteroventral corner of the epimera. The Algerian macrotelsonis clearly differs from vomeratus in shape of the basis of pereiopods 5 to 7 , width of the propodus of gnathopod 2, and armature of the uropods. Ps. illustris from the Río Guadalbullón in the province of Jaén differs further from this species in the presence of combed spines on the outer lobe of maxilla 1 , short pereiopod 5, and armature of the uropods. With the exception of epimeral plates, telson, and maxilla 1 (in which 8 spines are found on the outer lobe of a large male), vomeratus resembles the species of the branchiatus group.

Etymology. - The proposed name for this species vomeratus (from the Latin vomer = ploughshare) alludes to the shape of the epimeral plates.

\section{Pseudoniphargus illustris n. sp. (Figs. 18-19)}

Material examined. - Prov. Jaén, Cambil, SBR Río Guadalbullón, near La Ramona, UTM coordinates VG467679, alt. 610 m; 21 July 1985 (sta. A85-7/62), 1 \% holotype, 1 ovigerous $\$$ allotype, $300^{\circ} 0^{*}, 7$ ovigerous $\$$, and about 100 other specimens (paratypes) (ZMA coll. no. Amph. 108.137).

Prov. Jaén, Carchelejo, SBR Río Guadalbullón, near Ermita de Santa Lucia, UTM coordinates VG471625, alt.

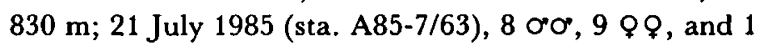
juv. (paratypes) (ZMA coll. no. Amph. 108.139).

Description. - Males up to $8.0 \mathrm{~mm}$; ovigerous females ranging from 4.6 to $6.1 \mathrm{~mm}$, carrying 2-4 eggs.

Male: Antenna $150-60 \%$ of body length, peduncle poorly setose, somewhat longer than that of antenna 2; flagellum 15- to 21segmented, aesthetascs about $1 / 3$ of length of corresponding segments, that of penultimate segment as long as this segment (fig. 18a). Antenna 2 (fig. 18b): peduncle segments with short setae only; flagellum 6- to 8-segmented, about 1.5 times as long as peduncle segment 5 , bearing short setae.

Mandible palp (fig. 18c): ventral surface of segment 2 with sparse setation; segment 3 with 1 A-seta, 2 B-setae, about 11 D-setae, and 4 E- setae. Maxilla 1 (fig. 18d): outer lobe with slender spines, 5 of which with regular row of long denticles appearing a comb, other spines smooth; $8.0 \mathrm{~mm}$ large male with anomalous palp which has one unarmed segment only. Maxillipedal (fig. 18e) inner and outer lobe rather wide. Other mouthparts without peculiarities.

Gnathopod 1 (fig. 19a): coxal plate rather wide with 2-3 short distal setae; carpus (fig. 19b) slightly longer than propodus, with 5 setal rows on posterior margin; palmar angle (fig. 19c) with 6 spines; unguis $2 / 3$ of length of dactylus. Gnathopod 2 (fig. 19d): coxal plate as that of gnathopod 1; carpus short, posteriorly with 3 setal groups; propodus (fig. 19e) with 3 setal groups on posterior margin, palma oblique with concave margin, palmar angle spines short; unguis half of length of dactylus.

Pereiopods 3 and 4 (fig. 19f): coxal plate 3 (fig. 18f) rather wide with 3-4 distal setae, plate 4 with shallow posterior excavation, posterior margin of propodus with about 5 elements; claw short.

Pereiopods 5 (fig. 19g) slightly shorter than pereiopods 3 and 4 , conspicuously shorter than pereiopod 6; basis rather wide, particularly in proximal part, margins convex, posterior lobe slightly widened and non-overhanging; distal segments with few, small spines; claw slender, unguis about half of length of dactylus. Pereiopod 6 (fig. 19h): basis slender with straight margins, posterior lobe narrow and non-overhanging, posterodistal angle subrectangular, anterior margin with 3 short spinules, posterior margin with 7 short setules, each implanted in a distinct notch (fig. 19j); armature on distal segments and claw as in pereiopod 5. Pereiopod 7 (fig. 19i): strongly elongate, basis and armature on distal segments as in pereiopod 6, unguis about half of length of dactylus.

Epimera (fig. 18k) with 1 small spine on ventral margin of plates 2 and 3; posteroventral corner strongly produced; posterior margin slightly S-shaped with few, small setules.

Uropod 1 (fig. 18g): peduncle with basoventral spine, 3 dorsal spines, 1 medial spine, and 


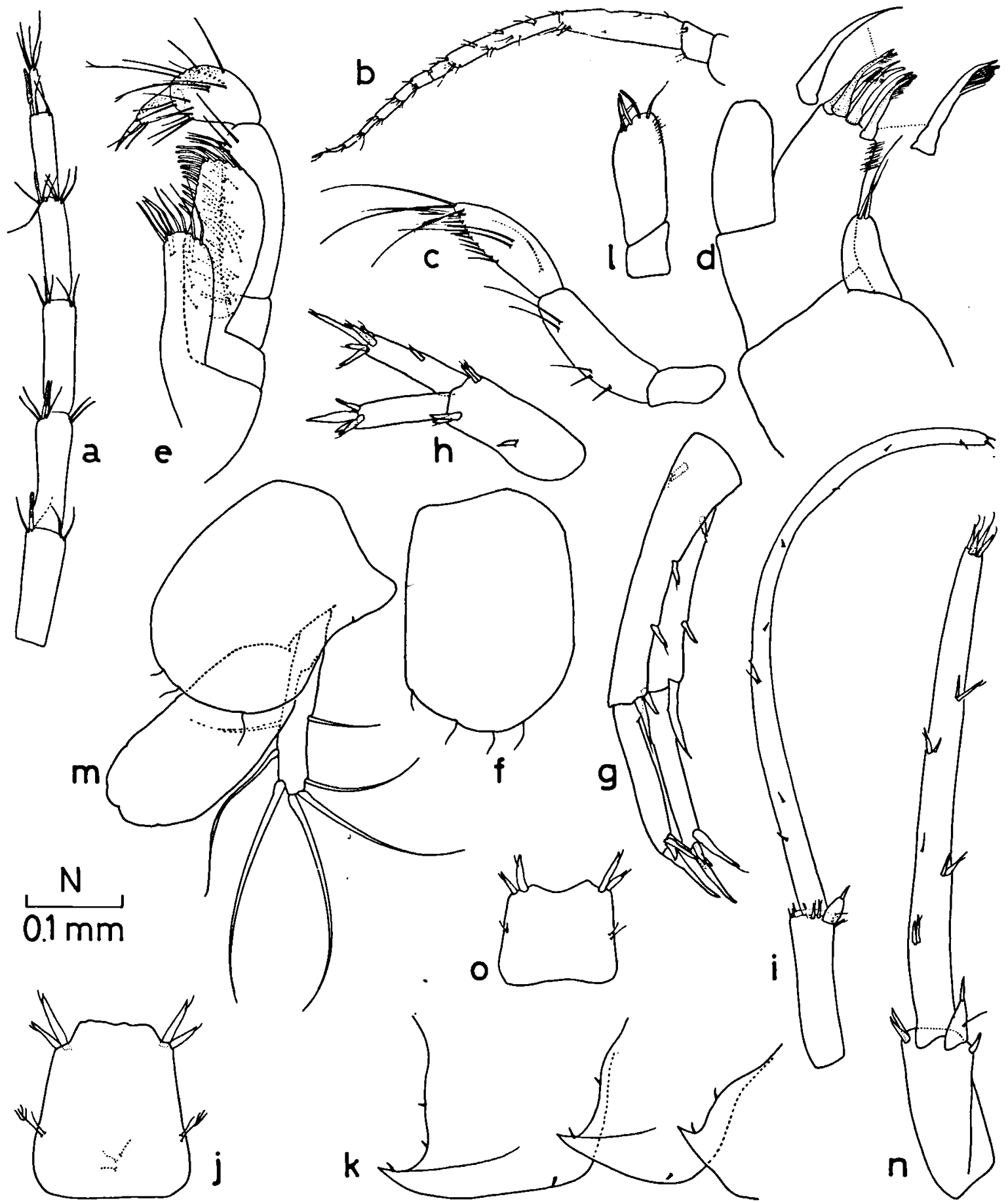

Fig. 18. Pseudoniphargus illustris n. sp. (a-k, $\sigma$ paratype $8.7 \mathrm{~mm}$; l-o, ovigerous $Q$ paratype $6.0 \mathrm{~mm}$; both from Cambil): a, distal part antenna 1 (scale B); b, antenna 2 (A); c, mandible palp (B); d, maxilla 1 (N); e, maxilliped (B); f, coxal plate pereiopod $3(\mathrm{O})$; g, uropod $1(\mathrm{O})$; h, uropod $2(\mathrm{O})$; i, uropod $3(\mathrm{~A})$; j, telson (B); k, epimera (A); l, palp maxilla $1(\mathrm{~N}) ; \mathrm{m}$, coxal plate pereiopod 4 (O); n, uropod 3 (B); o, telson (B). 


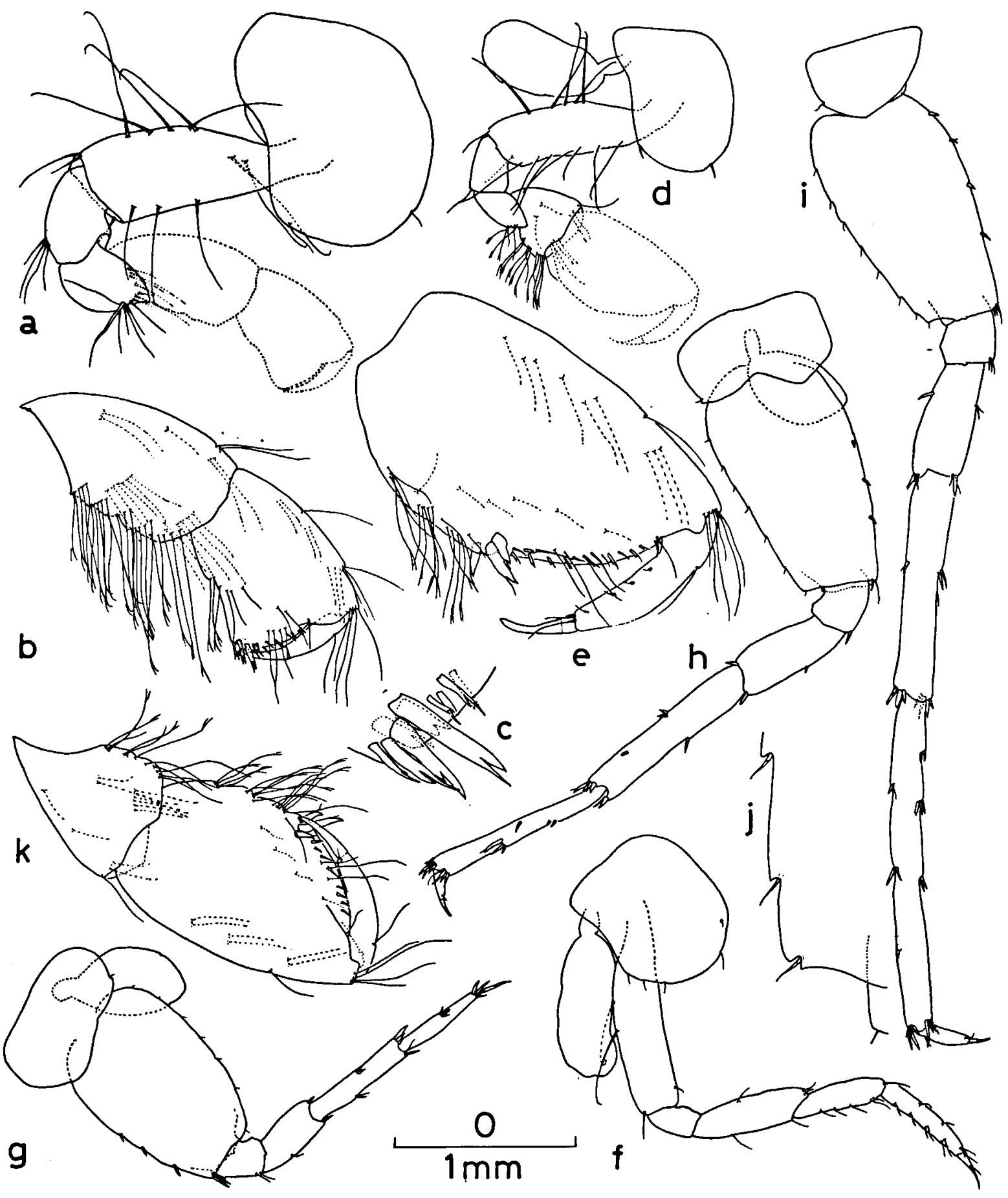

Fig. 19. Pseudoniphargus illustris n. sp. (a-j, ơ paratype $8.7 \mathrm{~mm} ; \mathrm{k}, Q$ paratype $6.1 \mathrm{~mm}$; both from Cambil): a, gnathopod 1 (scale O); b, distal part gnathopod 1 (B); c, palmar angle gnathopod 1 (D); d, gnathopod 2 (A); e, distal part gnathopod 2 (B); f, pereiopod 4 (A); g, pereiopod 5 (A); h, pereiopod 6 (A); i, pereiopod 7 (A); j, distal part posterior margin basis pereiopod 7 (D); $k$, distal part gnathopod 2 (B). 
distomedial spine reaching up to half the length of endopodite; rami without marginal armature, terminal spines short, exopodite slightly shorter than endopodite. Uropod 2 (fig. 18h): peduncle with 1 dorsal spine and 2 distal spines on either side; exopodite with 1 marginal spine, terminal spines short. Uropod 3 (fig. 18i): peduncle about 4 times as long as wide (23 times longer than telson), with short distal spines only; exopodite strongly elongated, about 22.5 times as long as wide, upcurved and with few elements.

Telson (fig. 18j) longer than wide, tapering; distal margin slightly undulated or with very shallow and wide notch; 2 short subterminal spines on either side.

Female: Carpus of gnathopod 1 and propodus of gnathopod 2 (fig. 19k) more slender than in male. Coxae 3 and 4 (fig. 18m) slightly deeper than in male. Oostegites with about 6 setae. Uropod 3 (fig. 18n): peduncle twice as long as wide; exopodite about 11.5 times as long as wide, spine groups on margins each of 2 short spines. Remaining characters as in male; the telson (fig. 18-o) and the palp of maxilla 1 (fig. 18-l) are additionally illustrated.

Remarks. - Apart from the species of the branchiatus group, and vomeratus, this is the only other species in southern Spain characterized by an elongated male uropod 3. Ps. illustris can be recognized easily by the combed spines on the outer lobe of maxilla 1 and the pereiopod 5 shorter than 4 . Other characters in which this species differs from the branchiatus group are: long telson, produced posteroventral corner of epimera, and armature of exopodite of female uropod 3. See also remarks under vomeratus.

At both localities this species was found together with latipes, which is hitherto the only record of co-occurring Pseudoniphargus species in Spain. The two species illustris and latipes are clearly distinct by many characters in mouthparts, gnathopods, epimera, uropods, and telson.

Etymology. - The name illustris (= illuminated; figurative: clear) is proposed for this species because it bears some distinct features by which it is easy to distinguish from other species of Pseudoniphargus.

\section{Pseudoniphargus margalefi n. sp. (Figs. 20-21)}

Material examined. - Prov. Alicante, Benidoleig, artificial resurgence below Cueva de las Calaveras, $1 \mathrm{~km}$ E.N.E. of Benidoleig, UTM coordinates YH591983, alt. $100 \mathrm{~m} ; 7$ Feb. 1984 (sta. 84-2/24), 1 O holotype, 1 ovigerous $\%$ allotype, $14 \sigma^{\circ} \sigma^{\circ}$ and $15 \%$ 우 (paratypes) (ZMA coll. no. Amph. 108.128).

Description. - Largest male $3.8 \mathrm{~mm}$; largest female (ovigerous) $4.2 \mathrm{~mm}$, carrying 1 egg.

Male: Antenna 1 about half as long as body; peduncle (fig. 20a) poorly setose, slightly shorter than that of antenna 2, segment 1 with 1 distal spine; flagellum of about 12 segments, aesthetascs $1 / 2-1 / 3$ of length of corresponding segments, that on penultimate segment longer than this segment (fig. 20b). Antenna 2 (fig. 20c): peduncle segments 4 and 5 with long setae, segment 4 with 2 rather long distal spines; flagellum slightly longer than peduncle segment 5 .

Mandible palp (fig. 20d): segment 2 with sparse ventral setation; segment 3 with $1 \mathrm{~A}$ seta, 1 B-seta, 8-10 D-setae, and 3 E-setae. Maxilla 1: spines on outer lobe smooth or unidenticulate. Maxillipedal outer lobe rather wide, palp slender.

Gnathopod 1: coxal plate similar to that of gnathopod 2; carpus slightly shorter than propodus; unguis half as long as dactylus. Gnathopod 2 (fig. 21a): coxal plate with $1+2$ distal setae; carpus short; propodus with 4 setal groups on posterior margin; palmar margin slightly convex with 3 spines on its angle; unguis $1 / 3$ of length of dactylus.

Pereiopods 3 and 4 (fig. 21c): coxal plate 3 (fig. 21b) subrectangular, with $1+2$ distal setae; coxal plate 4 with shallow posterior excavation and 3 distal setae; posterior margin of propodus with 4 and 5 spinules, respectively; claw short, unguis as long as dactylus.

Pereiopods 5 to 7 (figs. 21d-f): basis with nar- 


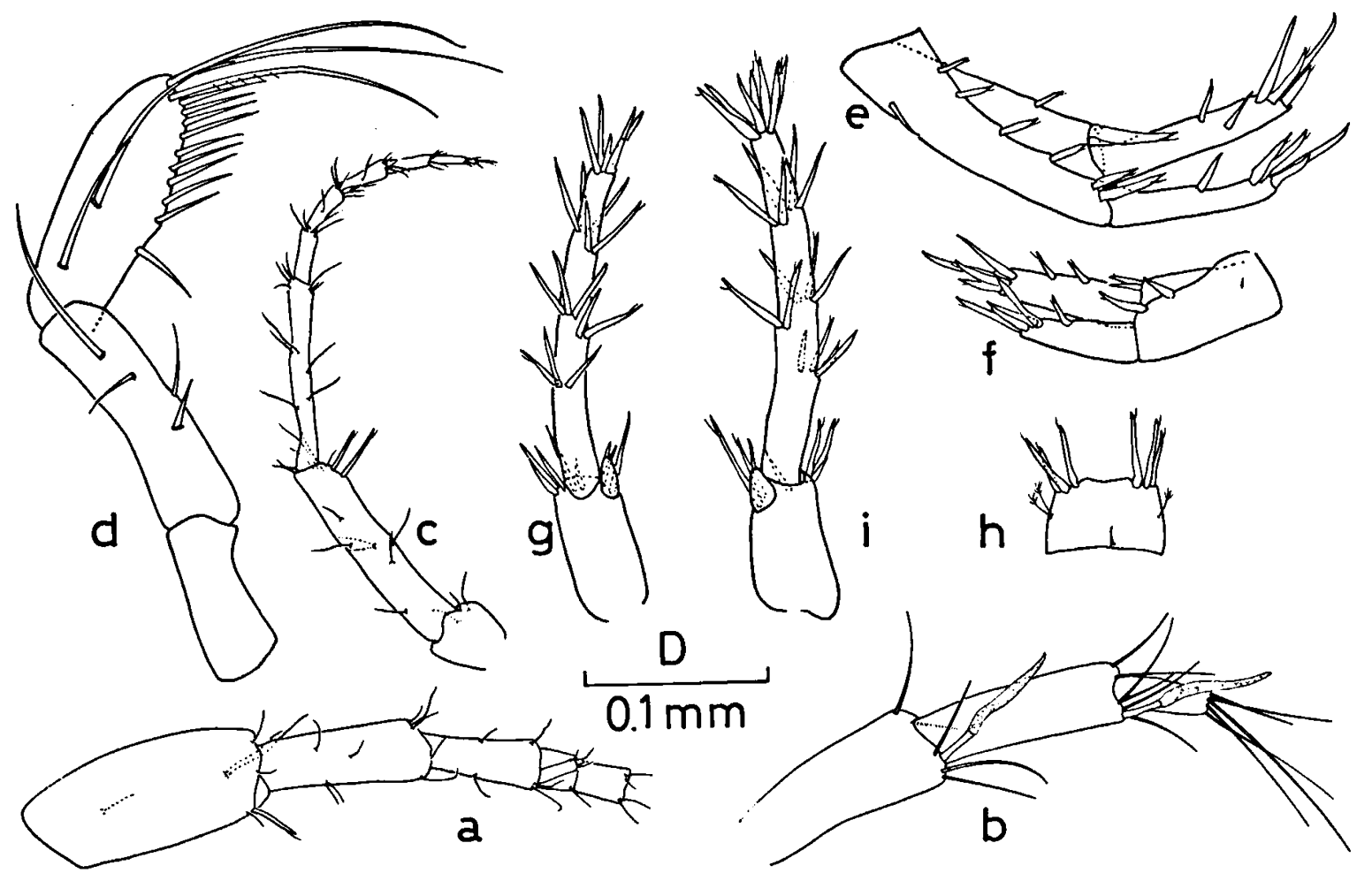

Fig. 20. Pseudoniphargus margalefi $\mathrm{n}$. sp. (a-h, $\sigma^{\circ}$ paratype $3.8 \mathrm{~mm}$; i, ovigerous $\$$ allotype $4.2 \mathrm{~mm}$; both from Calaveras): a, peduncle antenna 1 (scale B); b, distal part flagellum antenna 1 (D); c, antenna 2 (B); d, mandible palp (B); e, uropod 1 (B); f, uropod 2 (B); g, uropod 3 (B); h, telson (B); i, uropod 3 (B).

row posterior lobe, non-overhanging; basis of pereiopod 5 (fig. 21d) with convex margins, in succeeding pereiopods (figs. 21e, f) these margins are more straight, with 4-6 anterior spinules which are gradually longer distally; distal segments with numerous spines which are gradually longer from pereiopod 5 to 7 ; posterodistal angle of merus, carpus, and propodus particularly in pereiopods 5 and 6 with much longer spines; claw short in pereiopod 5 (fig. 21d), unguis slightly shorter than dactylus; claw of pereiopods 6 (fig. $21 \mathrm{~g}$ ) and 7 (figs. 21f, h) more slender, unguis about half of dactylus.

Epimera: lower margin of plate 2 convex, that of plate 3 straight, both with 1 spine; posteroventral corner rounded, posterior margin slightly convex with few rather long setules.

Uropod 1 (fig. 20e): peduncle with basoventral spine, a dorsal row of 4 spines, 1 medial spine, and a distomedial spine shorter than half the length of endopodite; exopodite obviously shorter than endopodite, with one marginal spine, endopodite with 2 marginal spines, terminal spines slender. Uropod 2 (fig. 20f): peduncle with 1 dorsal spine and 1-2 distal spines; exopodite clearly shorter than endopodite, with 1 marginal spine, endopodite with 2-3 marginal spines. Uropod 3 (fig. 20g): peduncle about twice as long as wide, with long distal spines; exopodite about 10 times as long as wide, margins with $2-3$ groups of spines, each group with up to 3 spines, terminal spines as long as marginal spines.

Telson (fig. 20h): wider than long, trapezoidal, with very shallow and wide distal emargination, which is vaguely crenulated, and 3 distal spines on either side.

Female: Similar to male. Oostegites with 8-10 setae. Uropod 3 (fig. 20i) and epimera (fig. 21i) illustrated. 


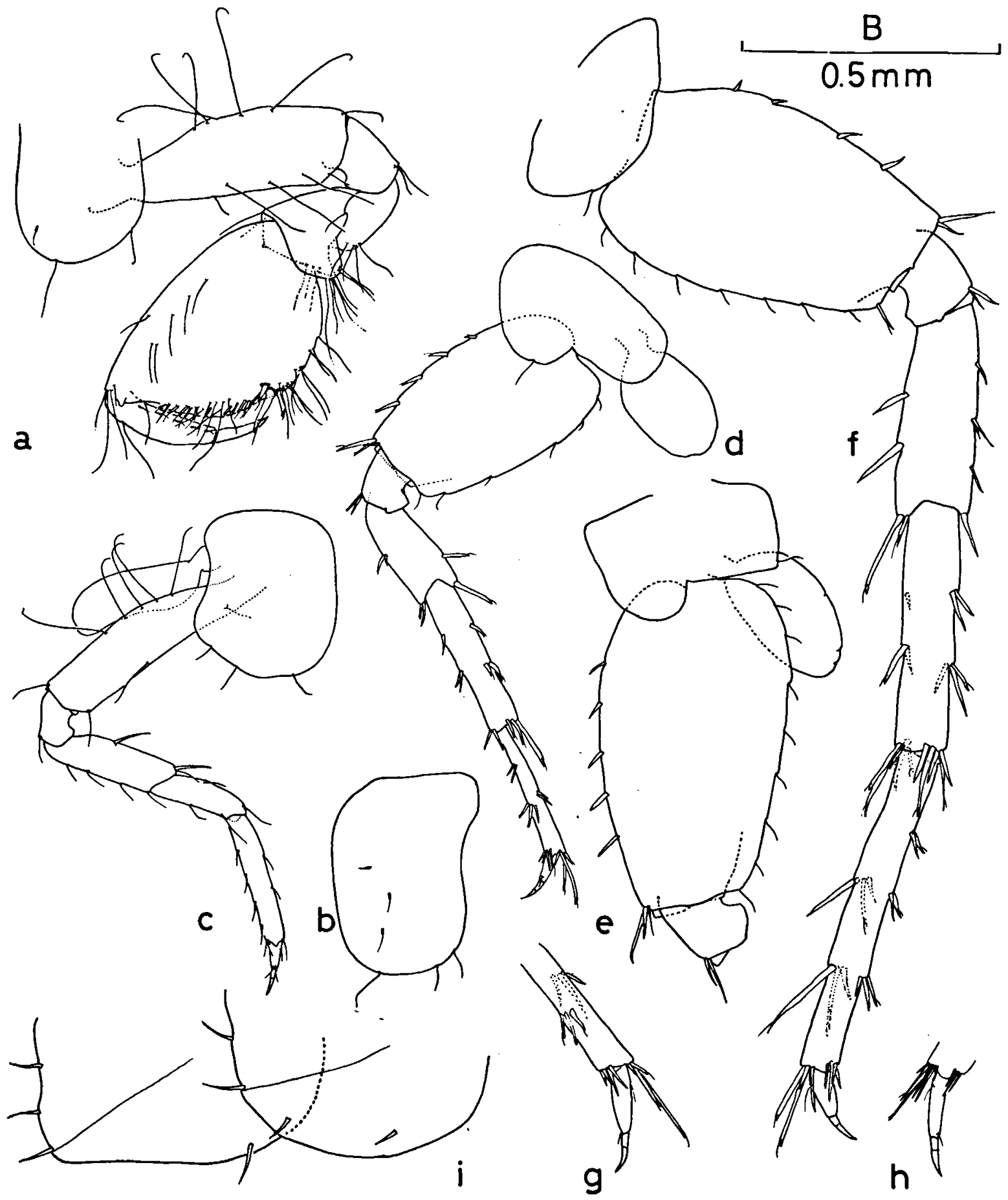

Fig. 21. Pseudoniphargus margalefi n. sp. (a-g, ơ paratype $3.8 \mathrm{~mm}$; h, $\sigma^{\circ}$ paratype $3.6 \mathrm{~mm}$; i, ovigerous $Q$ allotype 4.2 $\mathrm{mm}$; all from Calaveras): a, gnathopod 2 (scale B); b, coxal plate pereiopod 3 (B); c, pereiopod 4 (B); d, pereiopod 5 (B); e, basis pereiopod 6 (B); f, pereiopod 7 (B); g, claw pereiopod 6 (B); h, claw pereiopod 7 (B); i, epimeral plates 2 and $3(B)$. 
Remarks. - Ps. margalefi was found in an artificial resurgence in connection with the subterranean river of Cueva de las Calaveras. Presumably the species inhabits the waters of the cave itself and other karstic aquatic biotopes as well.

Among the species in which uropod 3 male and basis of posterior pereiopods are not elongated, margalefi is distinguished by relatively weak features: short and hardly emarginate telson, exopodite of uropods 1 and 2 obviously shorter than endopodite, and the shape of the epimera.

Etymology. - This species is named after Prof. Dr. R. Margalef (Barcelona) in recognition of his contributions to the knowledge of Iberian crustaceans and his stimulating influence on the development of ecological studies on terrestrial, freshwater and marine communities.

Pseudoniphargus cazorlae n. sp.

(Figs. 22-23)

Material examined. - Prov. Jaén, Cazorla, SBR Río Guadalquivir, near Puente de las Herrerías, UTM coordinates WG 055951, alt. $1000 \mathrm{~m}$; 28 July 1985 (sta. A85-7/77), $1 \sigma^{\circ}$ holotype, 1 allotype, $40^{\circ} 0^{\circ}, 5$ 우 (1 ovigerous), and 23 small specimens (paratypes) (ZMA coll. no. Amph. 108.120).

Description. - Largest male and female, 4.6 and $3.8 \mathrm{~mm}$, respectively; only ovigerous female $3.7 \mathrm{~mm}$, carrying 1 egg.

Male: Antenna $150-60 \%$ of body length; peduncle (fig. 22a) segment 1 with 2 small ventral spines and 1 distal spine; flagellum (fig. $22 \mathrm{~b}$ ) 18-segmented, aesthetascs about $3 / 4$ of length of corresponding segments, that on penultimate segment longer than terminal segment. Antenna 2 (fig. 22c) with several setae, in particular peduncle segment 5 and flagellum; peduncle segment 3 with 2 distal spines, segment 4 with several marginal and 2 distal spines; flagellum 8-segmented, about 1.5 times as long as peduncle segment 5 .

Mandible palp (fig. 23a): segment 2 with sparse ventral setation; segment 3 with 1 Aseta, $1 \mathrm{~B}$-seta, $12 \mathrm{D}$-setae, and $3 \mathrm{E}$-setae. Outer lobe of maxilla 1 (fig. 23b) with smooth and unidenticulate spines. Maxillipedal palp (fig. 23c) slender, with long claw.

Gnathopod 1: carpus about as long as propodus (fig. 23d), with 4 setal rows on posterior margin. Gnathopod 2: coxal plate (fig. 23f) like that of gnathopod 1 (fig. 23e) with $1+2$ distal setae; carpus short; propodus (fig. 22d) posteriorly with 3 setal groups; palmar margin not very oblique; unguis about 0.4 of length of dactylus.

Pereiopods 3 and 4: coxal plates (figs. $23 \mathrm{~g}, \mathrm{~h}$ ) rectangular with 3 and 5 distal setae, respectively; plate 4 (fig. $23 \mathrm{~h}$ ) with shallow posterior excavation.

Pereiopods 5 to 7 (figs. 22e-g): basis slightly tapering with narrow non-overhanging posterior lobe; distal segments with many spines, distal propodal spines slightly longer than dactylus; claw of $\mathrm{P} 6$ and $\mathrm{P} 7$ slender, unguis about $1 / 2$ and $1 / 3$ of length of dactylus, respectively.

Epimera (fig. 23i): lower margin of plates 2 and 3 rather straight, both with 1 slender spine, posteroventral corner rounded with small tooth, posterior margin slightly convex with 3 setules.

Uropod 1 (fig. 23j): peduncle with slender basoventral spine, a row of 4 dorsal spines, 3 medial spines, and long distomedial spine exceeding half the length of endopodite; endopodite with 1 marginal spine, exopodite without marginal armature. Uropod 2 (fig. 23k): peduncle with 1 spine and 2 distal spines on either side; rami with 1 marginal spine on endopodite only. Uropod 3 (fig. 23-1): peduncle short, about twice as long as wide with 1 marginal and several long distal spines; exopodite not elongated, about 11 times as long as wide, margins with 2-4 groups of spines, each with 2-3 long spines; terminal spines about as long as marginal spines.

Telson (fig. $23 \mathrm{~m}$ ) wider than long, with rather deep distal emargination and 3 spines on either side.

Female: Oostegites with about 5 setae. Distal part of basis of pereiopods 5 to 7 (fig. 23n) slightly wider than in male. Remaining characters as in male. 


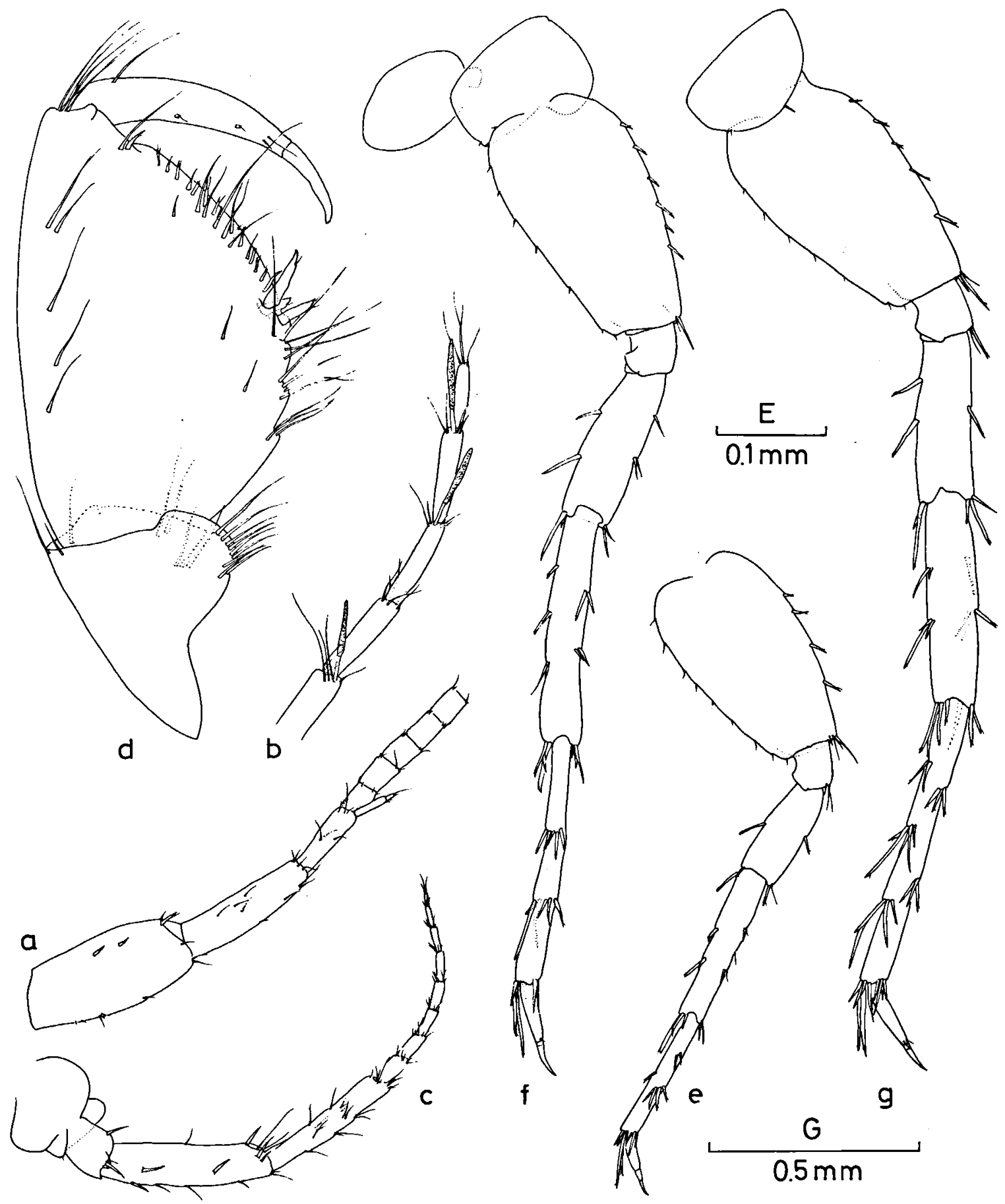

Fig. 22. Pseudoniphargus cazorlae n. sp., o paratype $4.6 \mathrm{~mm}$, from Puente de las Herrerías: a, peduncle antenna 1 (scale $\mathrm{G})$; b, distal part flagellum antenna $1(\mathrm{G})$; c, antenna $2(\mathrm{G})$; d, distal part gnathopod 2 (E); e, pereiopod 5 (G); f, pereiopod $6(\mathrm{G})$; g, pereiopod $7(\mathrm{G})$. 


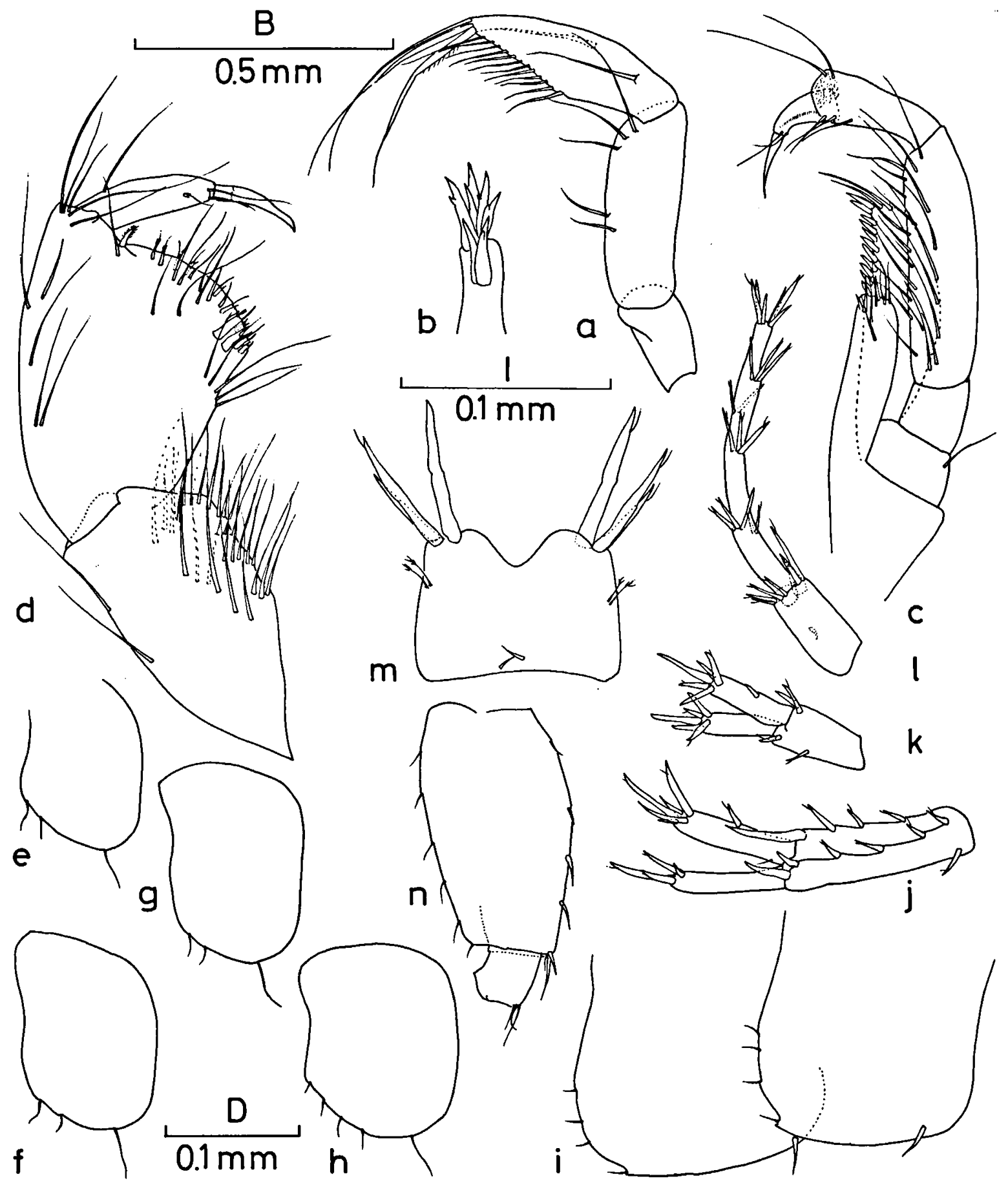

Fig. 23. Pseudoniphargus cazorlae n. sp. (a-m, o paratype $4.6 \mathrm{~mm} ; \mathrm{n}$, 9 paratype $3.6 \mathrm{~mm}$; both from Puente de las Herrerías): a, mandible palp (scale D); b, outer lobe maxilla 1 (I); c, maxilliped (D); d, distal part gnathopod 1 (B); e, coxal plate gnathopod 1 (B); f, coxal plate gnathopod 2 (B); g, coxal plate pereiopod 3 (B); h, coxal plate pereiopod 4 (B); i, epimeral plates 2 and 3 (B); j, uropod 1 (B); k, uropod 2 (B); l, uropod 3 (B); m, telson (D); n, basis pereiopod 7 (B). 
Remarks. - This species is characterized by its slender maxillipedal palp, elongated carpus of gnathopod 1 in both sexes, heavily spinose posterior pereiopods with slender claws, convex posterior margin of epimeral plates, nonelongate male uropod 3 bearing many long spines, and wide telson with deep distal notch.

$P$ s. cazorlae is very similar to margalefi but differs mainly in the shape of the telson and the armature and unequal length of the rami of uropods 1 and 2. The only other species of Pseudoniphargus likewise living in the underflow of the same river system, latipes, is clearly different from cazorlae by its wide propodus of gnathopod 1.

Etymology. - The proposed specific name cazorlae is a toponym referring to the Sierra de Cazorla, in which the type-locality is located.

\section{Pseudoniphargus latipes n. sp. (Figs. 24-26)}

Material examined. - Prov. Jaén, Santiago de la Espada, Coto Nacional de Cazorla, SBR Río Guadalquivir, $2 \mathrm{~km}$ downstream of Cotorrios, UTM coordinates WH1412, alt. $650 \mathrm{~m} ; 25 \mathrm{Jan} .1984$ (sta. 84-1/10), 1 o holotype, 1 allotype, $1 \odot$ and 1 juv. (paratypes) (ZMA coll. no. Amph. 108.119).

Prov. Jaén, Villacarillo, SBR Río Guadalquivir, near bridge S. of Mogón, UTM coordinates VH9613, alt. 400 m; 24 Jan. 1984 (sta. 84-1/4), 2 ơo', 1 \&, and 5 juvs. (paratypes) (ZMA coll. no. Amph. 108.134).

Prov. Jaén, Villanueva del Arzobispo, SBR Río Guadalquivir, $10 \mathrm{~km}$ E.N.E. of Villanueva del A., UTM coordinates WH0926, alt. $520 \mathrm{~m} ; 24$ Jan. 1984 (sta. 841/5), 5 partly damaged specimens and 7 juvs.

Prov. Albacete, Villaverde de Guadalimar, SBR Río Guadalimar, W. of Cotillas, UTM coordinates WH4154, alt. $740 \mathrm{~m}$; 25 Jan. 1984 (sta. 84-1/8), 5 ơ o and 7 ९.

Prov. Sevilla, well S. of Alcolea del Río, UTM coordinates TG6466, alt. 10-75 m; 24 July 1984 (sta. 84-7/19), 1 juv. (probably this species).

Prov. Sevilla, Peñaflor, SBR Río Retortillo, just downstream of Presa del Retortillo, UTM coordinates TG967800, alt. $55 \mathrm{~m}$; 1 July 1985 (sta. A85-7/2), $1 \sigma^{\prime \prime}$ and 1 juv.

Prov. Jaén, Cambil, SBR Río Guadalbullón, 4.5 km S.W. of Cambil, UTM coordinates VG467679, alt. 650 m; 21 July 1985 (sta. A85-7/62), 2 ơ o' and 3 \& ovigerous).

Prov. Jaén, Carchelejo, SBR Río Guadalbullón near Ermita de Santa Lucia, 4.5 km S.E. of Carchelejo, UTM coordinates VG4762, alt. 840 m; 21 July 1985 (sta. A857/63), 2 ơơ, 4 ९ , and 6 juvs.

Prov. Jaén, Pontones, Coto Nacional de Cazorla, SBR Río Aguamulas, $3 \mathrm{~km} \mathrm{N.E.} \mathrm{of} \mathrm{Cotorrios,} \mathrm{UTM} \mathrm{coor-}$ dinates WH155128, alt. 670 m; 28 July 1985 (sta. A857/78), $40^{\circ} 0^{\circ}, 1 \%$, and 2 damaged specimens.

Prov. Jaén, Santiago de la Espada, Coto Nacional de Cazorla, SBR Arroyo del Membrillo, $2.2 \mathrm{~km} \mathrm{S.W.} \mathrm{of}$ Cotorrios, UTM coordinates WH1210, alt. $650 \mathrm{~m} ; 28$ July 1985 (sta. A85-7/79), 1 \%.

Description. - Males up to $7.3 \mathrm{~mm}$; largest female (ovigerous) $9.0 \mathrm{~mm}$ (from Cambil), carrying 4 eggs.

Male (fig. 24): Antenna 1 (fig. 25f) 50-70\% of body length; peduncle, sparsely armed, reaching up to half the length of peduncle segment 5 of antenna 2; flagellum about 23segmented, with short setae, and aesthetascs about $1 / 2$ of length of corresponding segments. Antenna 2 (fig. 25g): peduncle very slender, segments 4 and 5 of the same length, segment 4 with few spines; flagellum 9- to 10segmented, bearing short setae, and slightly longer than peduncle segment 5 .

Mandible palp: segment 2 with several setae on ventral margin; segment 3 slender with $3 \mathrm{~A}$ setae, $1 \mathrm{~B}$-seta, about $19 \mathrm{D}$-setae, and $3 \mathrm{E}$ setae. Maxilla 1: outer lobe with 7 slender, multidenticulate spines. Maxillipedal inner lobe short, reaching up to half the length of outer lobe, outer lobe rather wide, and palp slender.

Gnathopod 1: coxal plate similar to that of gnathopod 2; carpus (fig. 25a) strong, about $2 / 3$ of length of propodus, posteriorly with 5 setal rows; propodus (fig. 25a) very strong, widened distally, posterior margin with 5 setal rows, palmar margin oblique with dense armature, palmar angle with 5 spines; unguis $1 / 3$ of length of dactylus. Gnathopod 2 (fig. 25b): coxal plate rather wide, subrectangular, distally with $1+3$ (or $1+4$ ) setae; carpus short; propodus rather wide with 4 setal groups on posterior margin, palmar margin very oblique and densely packed with bifid spinules, midpalmar setae rather few, palmar angle (fig. 25c) with 3 spines of which 1 rather long and 1 very small more 


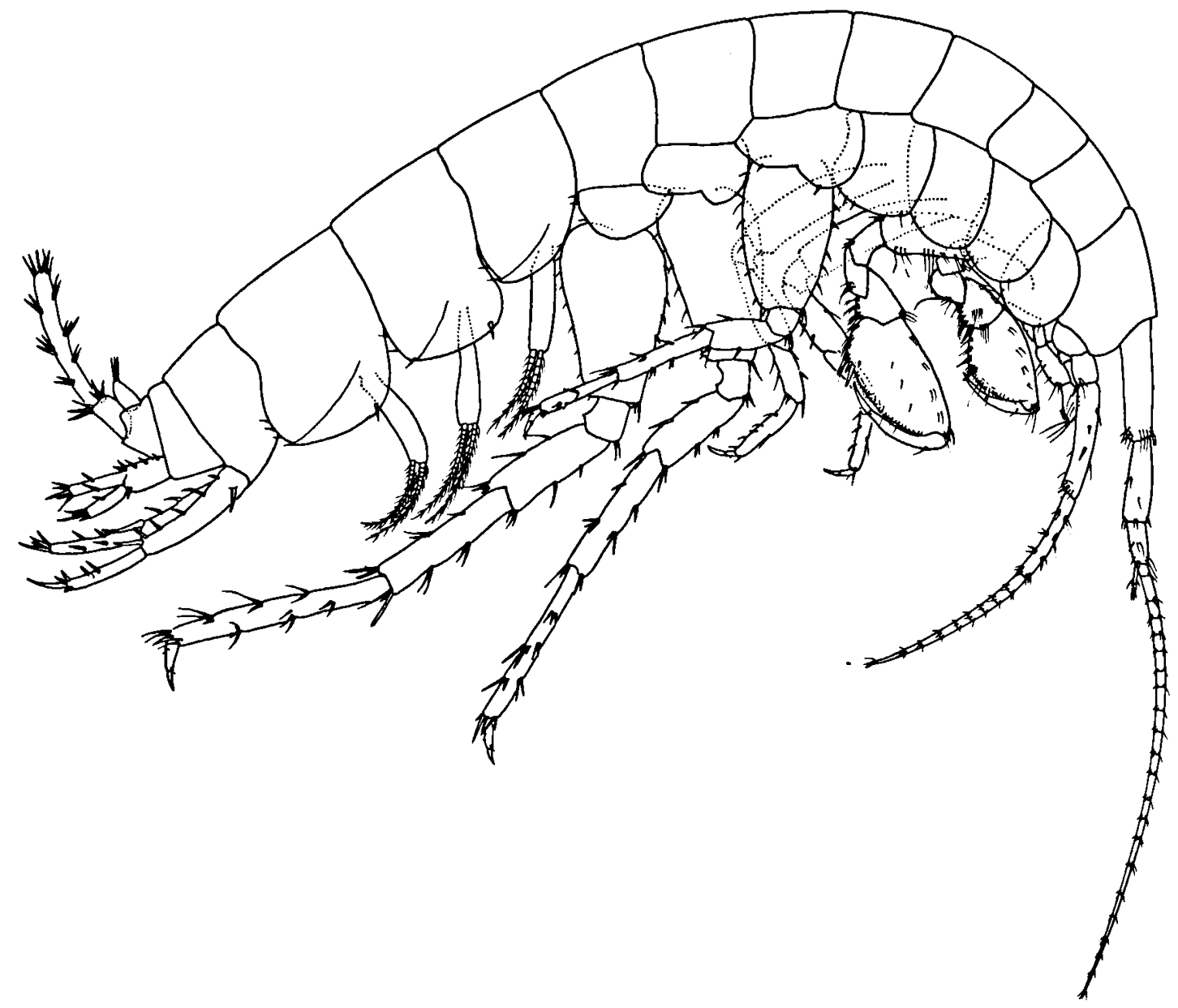

Fig. 24. Pseudoniphargus latipes n. sp., o $6.7 \mathrm{~mm}$, from Cambil.

interiorly implanted; unguis 1/3-1/4 of length of dactylus.

Pereiopods 3 and 4 (fig. 25i): coxal plate 3 (fig. $25 \mathrm{~h}$ ) subrectangular with $1+3$ distal setae, plate 4 rather wide with shallow posterior excavation and $1+5$ distal setae; posterior margin of propodus with 4 spinules and 1 setule (P3), and 5 spinules (P4); claw short, unguis about as long as dactylus.

Pereiopods 5 to 7: basis slender, with rather straight margins, and narrow non-overhanging posterior lobe, anterior margin with 6 spinules (P5 and P7) or 7 (P6) spinules, posterior margin with about 11 setules; distal segments with rather short elements in pereiopod 5 which are gradually longer in succeeding pereiopods; claw short, unguis slightly shorter than dactylus in pereiopod 5, and half the length of dactylus in pereiopods 6 and 7.

Epimera (fig. 26h): lower margin of plates 2 and 3 both with one slender spine, posteroventral corner rounded, posterior margin convex with 3 and 4 long setules, respectively.

Uropod 1 (fig. 25d): peduncle slender with basoventral spine, a dorsal row of 6 slender spines, 4 medial spines, and distomedial spine reaching up to $1 / 3$ of length of endopodite; rami slender, exopodite slightly shorter than endopodite, with 3-4 marginal spines, endopodite with 2 marginal spines, terminal spines slender. Uropod 2 (fig. 25e): peduncle with 3 dorsal spines and 2-3 distal spines on 


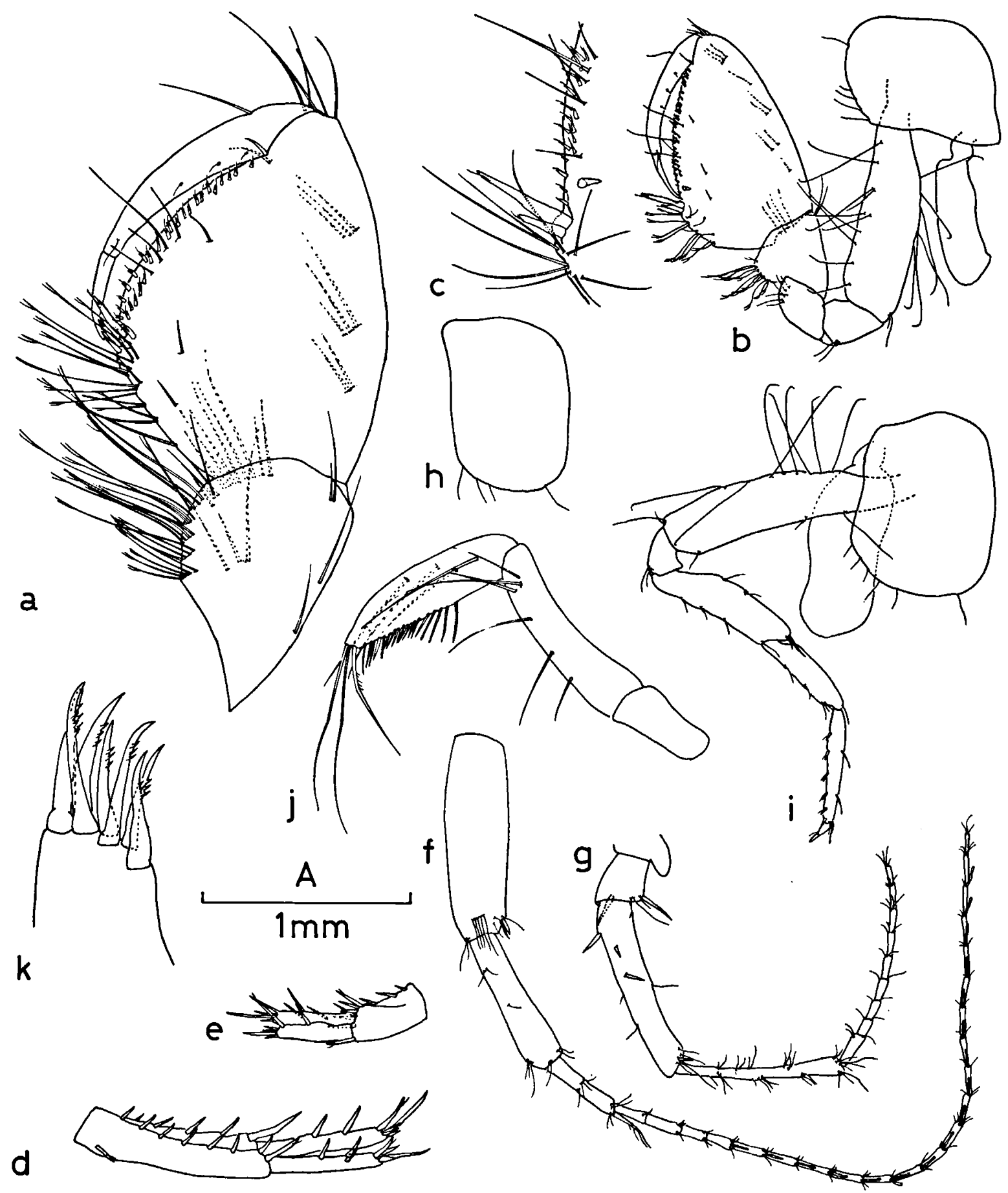

Fig. 25. Pseudoniphargus latipes n. sp. (a-e, $\sigma^{\circ}$ holotype $7.2 \mathrm{~mm}$, from Río Guadalquivir near Cotorrios; f-i, o paratype $6.5 \mathrm{~mm}$, from Río Guadalquivir near Mogón; j-k, $9.0 \mathrm{~mm}$, from Mogón): a, distal part gnathopod 1 (scale B); b, gnathopod 2 (A); c, palmar margin gnathopod 2 (D); d, uropod 1 (A); e, uropod 2 (A); f, antenna 1 (A); g, antenna 2 (A); h, coxal plate pereiopod 3 (A); i, pereiopod 4 (A); j, mandible palp (B); $k$, outer lobe maxilla 1 (D). 


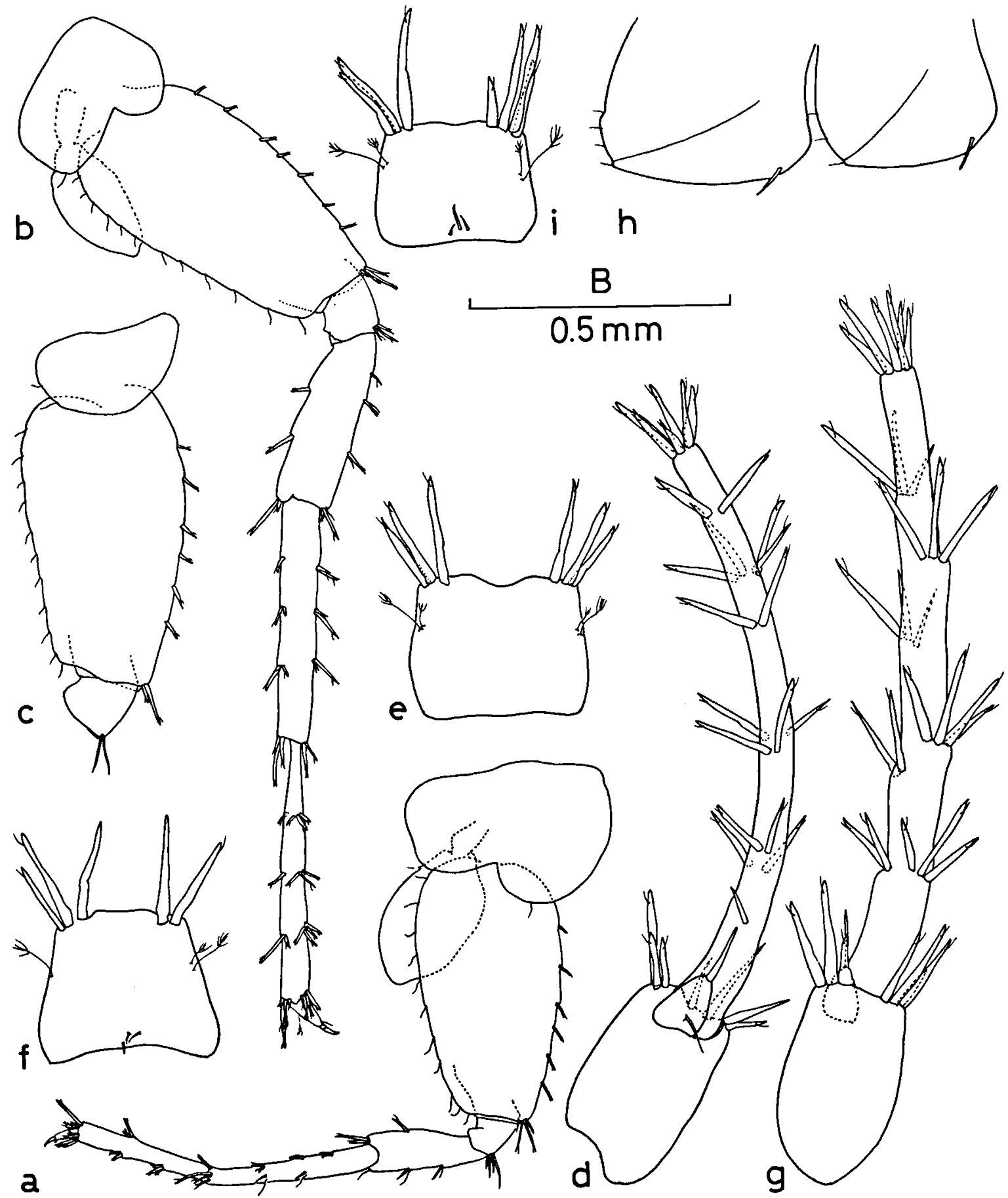

Fig. 26. Pseudoniphargus latipes $\mathrm{n}$. sp. (a-e, $९$ allotype $8.2 \mathrm{~mm}$, from Río Guadalquivir near Cotorrios; $\mathrm{f}$, $\uparrow$ paratype $7.0 \mathrm{~mm}$, from Río Guadalquivir near Mogón; g-h, $\sigma^{\circ}$ paratype $6.5 \mathrm{~mm}$, from Mogón; i, o holotype $7.2 \mathrm{~mm}$, from Cotorrios): a, pereiopod 5 (scale A); b, pereiopod 6 (A); c, basis pereiopod 7 (A); d, uropod 3 (B); e, telson (B); f, telson (B); g, uropod 3 (B); h, epimeral plates 2 and 3 (A); i, telson (B). 
either side; exopodite shorter than endopodite, with 1 marginal spine, endopodite with 3 marginal spines. Uropod 3 (fig. 26g): peduncle 1.5-2.0 times as long as wide, with long distal spines; exopodite 10.5 times as long as wide, margins with 3-4 spine groups, each group with 2-4 long spines, terminal spines slightly shorter than marginal spines.

Telson (fig. 26i): wider than long, distal notch shallow and wide, or not at all emarginated, with 2-4 spines on either side.

Female: Similar to male. Illustrated are mandible palp (fig. 25j), outer lobe of maxilla 1 (fig. 25k), pereiopods 5 to 7 (figs. 26a-c), uropod 3 (fig. 26d), and telson (figs. 26e-f). Oostegites with up to 10 setae.

Remarks. - This species of Pseudoniphargus seems to have the largest distribution in southern Spain. It has been found along the margins of the Guadalquivir basin in hyporheic habitats. The easternmost locality near Cotillas (Río Guadalimar) is about $256 \mathrm{~km}$ distant from the westernmost locality near Peñaflor (Río Retortillo). In the Río Guadalbullón near Carchelejo and Cambil latipes has been found together with illustris.

Ps. latipes is characterized by an elongate segment 3 of the mandible palp, strong and widened propodus of gnathopod 1, strong propodus with oblique palma and slender claw of gnathopod 2, short claws of pereiopods, slender basis of posterior pereiopods with narrow nonoverhanging posterior margin, rounded posteroventral corner of epimera, strongly spinose uropods, and non-elongated peduncle and exopodite of uropod 3 in males and females.

Etymology. - The proposed name latipes alludes to the strong and widened propodus of gnathopod 1 which distinguishes this species from all other known species of the genus.

\section{Pseudoniphargus gracilis n. sp.}

(Figs. 27-29)

Material examined. - Prov. Almería, Cantoria, well at Almanzora, $300 \mathrm{~m} \mathrm{S.W}$. of Estación de Albox,
UTM coordinates WG762337, alt. $330 \mathrm{~m} ; 19$ July 1985 (sta. 85-7/10), 1 ovigerous $\$$ holotype, 7 small specimens (paratypes) (ZMA coll. no. Amph. 108.133).

Prov. Almería, Cantoria, well at El Badil, UTM coordinates WG755341, alt. $440 \mathrm{~m}$; 19 July 1985 (sta. 857/11), 18 specimens (paratypes) (ZMA coll. no. Amph. 108.135).

Prov. Almería, Tijola, well E. of the road to Lúcar, 2 km N. of Tijola, UTM coordinates WG497352, alt. 680 m; 19 July 1985 (sta. 85-7/12), 1 ovigerous \&.

Description. - Largest female (ovigerous holotype) $5.0 \mathrm{~mm}$, ovigerous female from Tijola $4.3 \mathrm{~mm}$, both carrying 3 eggs. Largest male $3.5 \mathrm{~mm}$.

Female: Antenna $150-60 \%$ of body length; peduncle (fig. 28a) as long as that of antenna 2, segments distally with some long setae; flagellum of 19 segments, aesthetascs about as long as corresponding segments. Antenna 2 (fig. 28b): peduncle slender, segment 4 with few dorsal spines, segments 4 and 5 with some long distal setae; flagellum 8-segmented, as long as peduncle segments 4 and 5 together.

Mandible palp: slender, segment 2 with 1 ventral and 1 distoventral seta, segment 3 with 1 A-seta, 5 D-setae, and 3 E-setae. Outer lobe of maxilla 1 with unidenticulate spines only, 2 outer spines stronger than other spines.

Gnathopod 1 (fig. 27a) very slender; coxal plate with 1 distal seta; carpus elongate, longer than propodus, with 5 setal rows on posterior margin; propodus elongate; palmar margin (fig. 27b) poorly armed, palmar angle with 5 spines; unguis about $2 / 3$ of length of dactylus. Gnathopod 2 (fig. 27c) very slender; coxal plate with $1+2$ ventral setae; carpus elongate posteriorly with 4 setal groups; propodus slender, posterior margin with 3 setal groups, palmar margin (fig. 27d) oblique, concave and poorly armed, palmar angle with 2 spines; unguis $1 / 2-1 / 3$ of length of dactylus.

Pereiopods 3 and 4 (fig. 28d): coxal plate 3 (fig. 28c) subrectangular with $1+2$ distal setae; plate 4 wider than plate 3 , posteriorly excavate, with $1+2$ distal setae; distal segments with few but rather long setae, posterior margin of propodus with 2-3 spines and one seta; unguis 


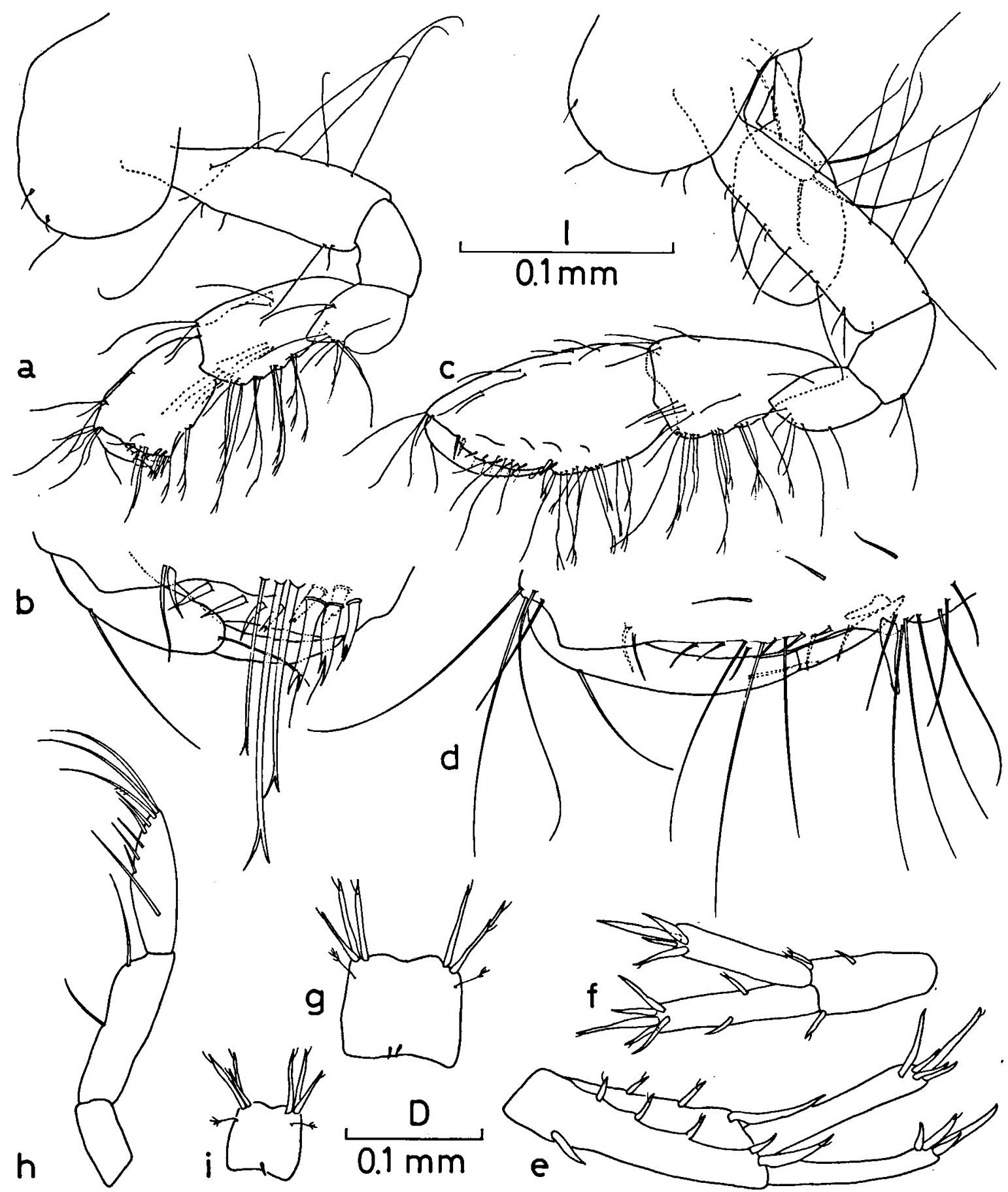

Fig. 27. Pseudoniphargus gracilis n. sp. (a-g, ovigerous $\$$ holotype $5.0 \mathrm{~mm}$, from Almanzora; h-i, ơ paratype $3.5 \mathrm{~mm}$, from El Badil): a, gnathopod 1 (scale B); b, palmar margin gnathopod 1 (I); c, gnathopod 2 (B); d, palmar margin gnathopod 2 (D); e, uropod 1 (B); f, uropod 2 (B); g, telson (B); h, mandible palp (D); i, telson (B). 


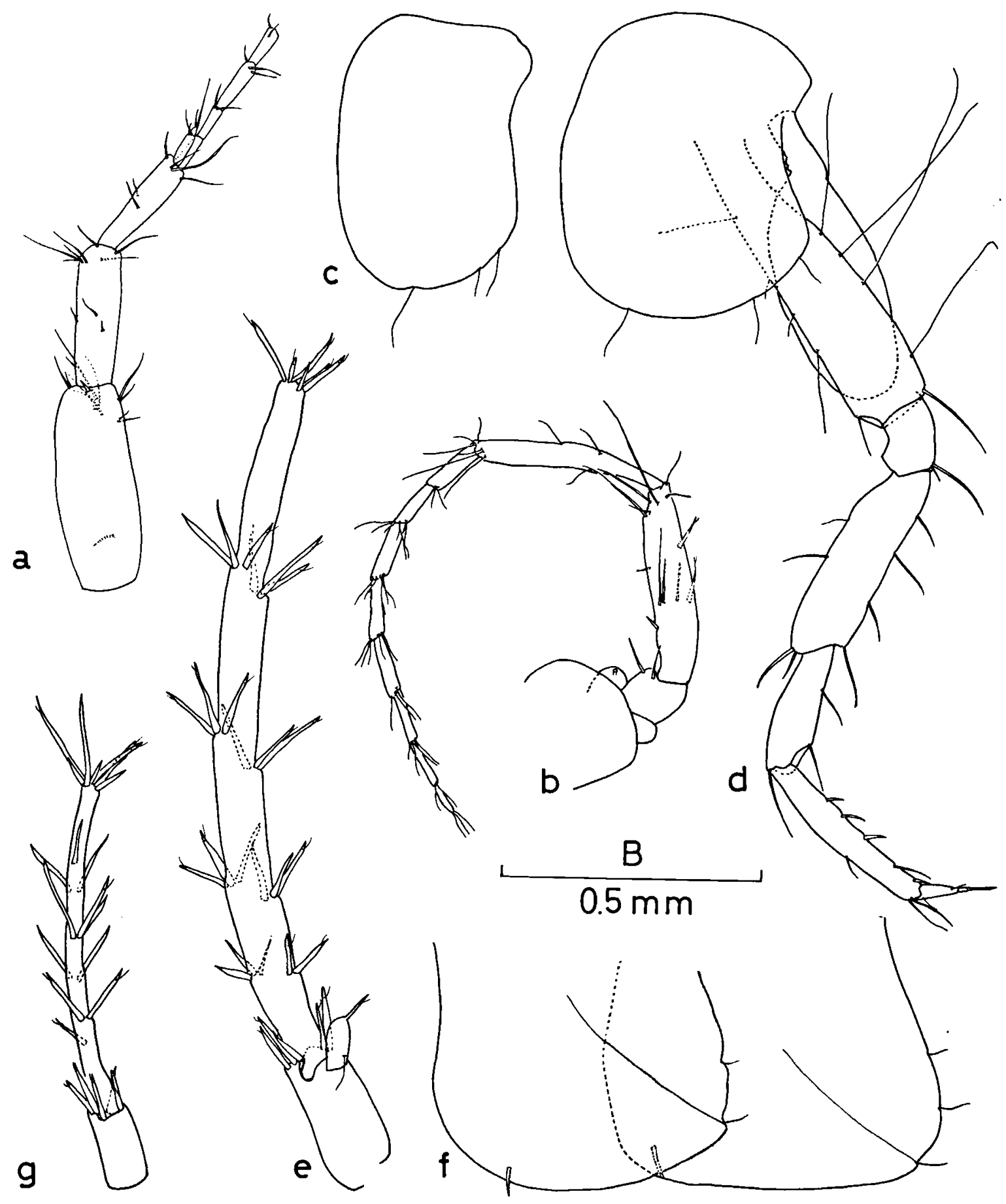

Fig. 28. Pseudoniphargus gracilis $\mathrm{n}$. sp. (a-f, ovigerous $\$$ holotype $5.0 \mathrm{~mm}$, from Almanzora; $\mathrm{g}$, o paratype $3.5 \mathrm{~mm}$, from El Badil): a, peduncle antenna 1 (scale B); b, antenna 2 (B); c, coxal plate pereiopod 3 (B); d, pereiopod 4 (B); e, uropod 3 (B); f, epimeral plates 2 and 3 (B); g, uropod 3 (B). 


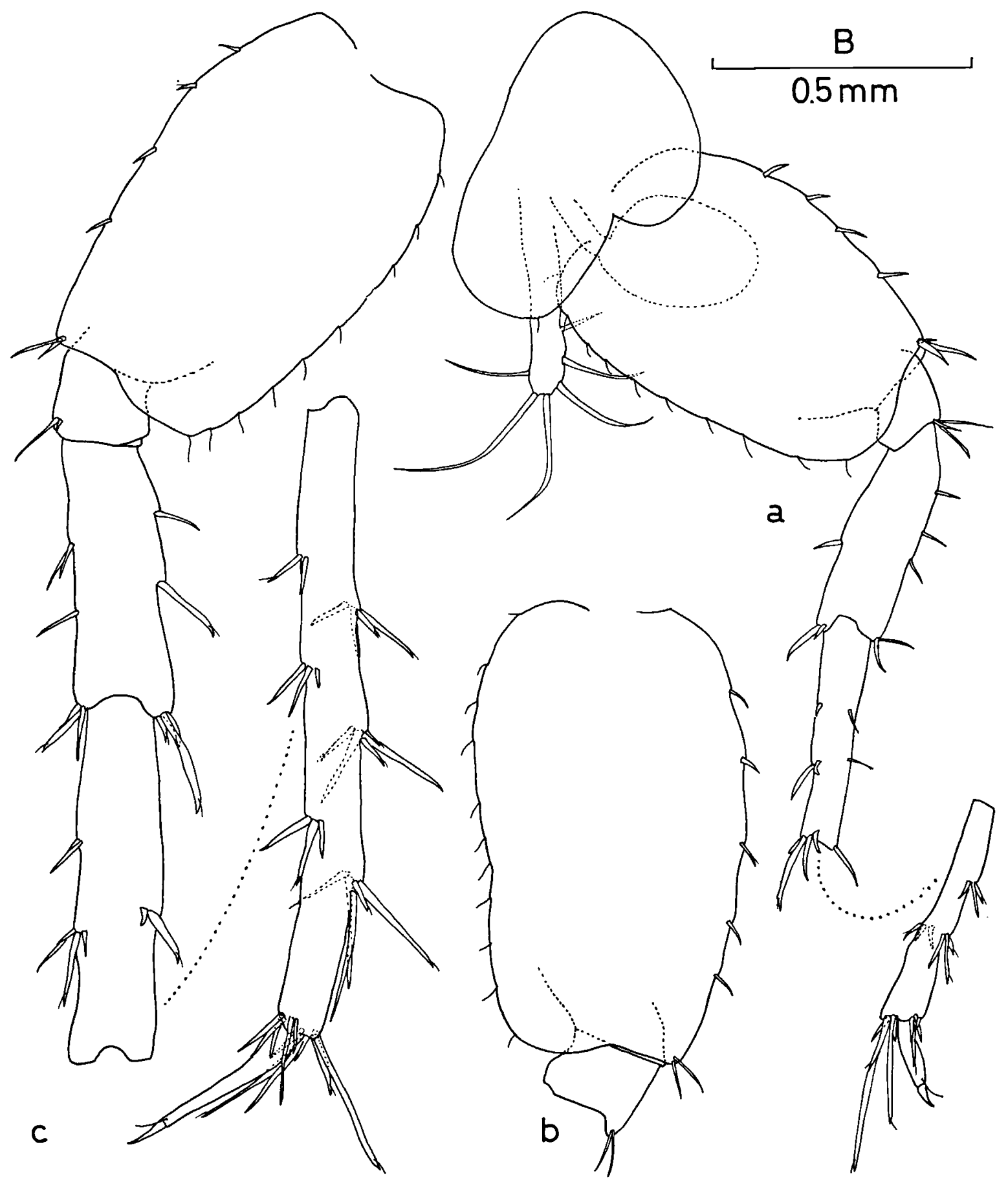

Fig. 29. Pseudoniphargus gracilis $\mathrm{n}$. sp., ovigerous $९$ holotype $5.0 \mathrm{~mm}$, from Almanzora: a, pereiopod 5 (scale B); b, basis pereiopod 6 (B); c, pereiopod 7 (B). 
slender, about as long as dactylus. Oostegites with 6 setae.

Pereiopods 5 to 7 (figs. 29a-c): basis rather wide with convex margins, posterior lobe wide and overhanging, anterior margin with 4-5 spinules, posterior margin with 9 (P5 and P7) or 11 (P6) setules. Distal segments with long and rather strong spines, distal propodal spine in pereiopod 5 exceeding the length of the claw, that of pereiopod 7 as long as dactylus. Unguis about $1 / 3$ of length of dactylus. Claw progressively longer in pereiopods 5 to 7 .

Epimera (fig. 28f): lower margin of plates 2 and 3 both with 1 spine, posteroventral corner slightly rounded, posterior margin, slightly convex, with few long setules.

Uropod 1 (fig. 27e): peduncle with strong basoventral spine, a row of 3 dorsal spines, 2 medial spines, and distomedial spine reaching just to half the length of endopodite; rami without marginal armature. Uropod 2 (fig. 27f): peduncle with 1 dorsal spine, and 1-2 distal spines on either side; exopodite shorter than endopodite without marginal armature, endopodite with 2 marginal spines. Uropod 3 (fig. 28e): peduncle almost twice as long as wide; exopodite slender, about 14 times as long as wide, margins with 4 groups of spines, each group with up to 3 long spines, terminal spines as long as marginal spines.

Telson (fig. $27 \mathrm{~g}$ ): about as long as wide, distal notch wide and shallow, with 3 subterminal spines on either side.

Male: As in female, probably smaller. Figured are mandible palp (fig. 27h), uropod 3 (fig. $28 \mathrm{~g}$ ), and telson (fig. 27i).

Remarks. - As presently known this species is distributed only in the valley of the Río Almanzora.

Ps. gracilis stands out by its slender and elongate carpus and propodus of gnathopods 1 and 2, weakly setose mandible palp, wide posterior lobes of basis and elongate dactylus in pereiopods 5 to 7 , and rather long and spinose exopodite of uropod 3. By a combination of these characters it is different from any other species in the genus. In northern Spain longicarpus and burgensis are the only taxa in which the carpus and propodus of gnathopod 2 are slender and elongate, but these species differ from gracilis in many other features.

Etymology. - The proposed specific name gracilis refers to the slender distal segments in the gnathopods of this species.

\section{Pseudoniphargus sorbasiensis $\mathbf{n}$. sp. (Figs. 30-31)}

Material examined. - Prov. Almería, Sorbas, well near Río de Aguas, just S.W. of viaduct in the road to Cuevas de Almanzora, at the S.E. side of Sorbas, UTM coordinates WG7806, alt. 350 m; 20 July 1985 (sta. 857/16), 1 ovigerous $\$$ holotype, $1 \sigma^{\circ}$ allotype, 7 \& $(4$ ovigerous), and 9 juvs. (paratypes) (ZMA coll. no. Amph. 108.136).

Prov. Almería, Sorbas, cave stream in Sistema la Fuente del Peral, UTM coordinates WG7904, alt. $450 \mathrm{~m}$; 30 Jan. 1984 (sta. 84-1/29), 1 juv. (probably this species).

Prov. Almería, Sorbas, well E. of the road to Nijar at Peñas Negras, $8.5 \mathrm{~km}$ S.E. of Sorbas, UTM coordinates WG8401, alt. $300 \mathrm{~m}$; 31 Jan. 1984 (sta. 84-1/30), 2 juvs. (probably this species).

Prov. Almería, Uleila del Campo, well near Caserio de Casa Blanca, just S. of the road to Sorbas, UTM coordinates WG739133, alt. $500 \mathrm{~m}$; 20 July 1985 (sta. 857/15), 1 juv. (probably this species).

Prov. Almería, Turre, well at La Noria, Los Giles, 10.5 km E.N.E. of Sorbas, UTM coordinates WG882093, alt. $150 \mathrm{~m}$; 20 July 1985 (sta. 85-7/17), 1 juv. (probably this species).

Description. - Largest female (holotype) $9.0 \mathrm{~mm}$, carrying 3 eggs; single male $5.0 \mathrm{~mm}$ (antennae damaged).

Female: Antenna $150-60 \%$ of body length; peduncle slightly longer than that of antenna 2, segment 1 with 1 distoventral spine; flagellum 19- to 24-segmented, aesthetascs $1 / 2-2 / 3$ of length of corresponding segments. Antenna 2 (fig. 30a): peduncle with many long setae, segment 3 with several distal spines, segment 4 with some small spines; flagellum 6- to 8segmented, shorter than peduncle segment 5 .

Mandible palp (fig. 30b): segment 2 with setose ventral margin; segment 3 with $1 \mathrm{~A}$-seta, 2 B-setae, about $16 \mathrm{D}$-setae, and $3 \mathrm{E}$-setae. Maxilla 1: inner lobe with 3 distal setae (one shorter), outer lobe (fig. 30c) with 4 multiden- 


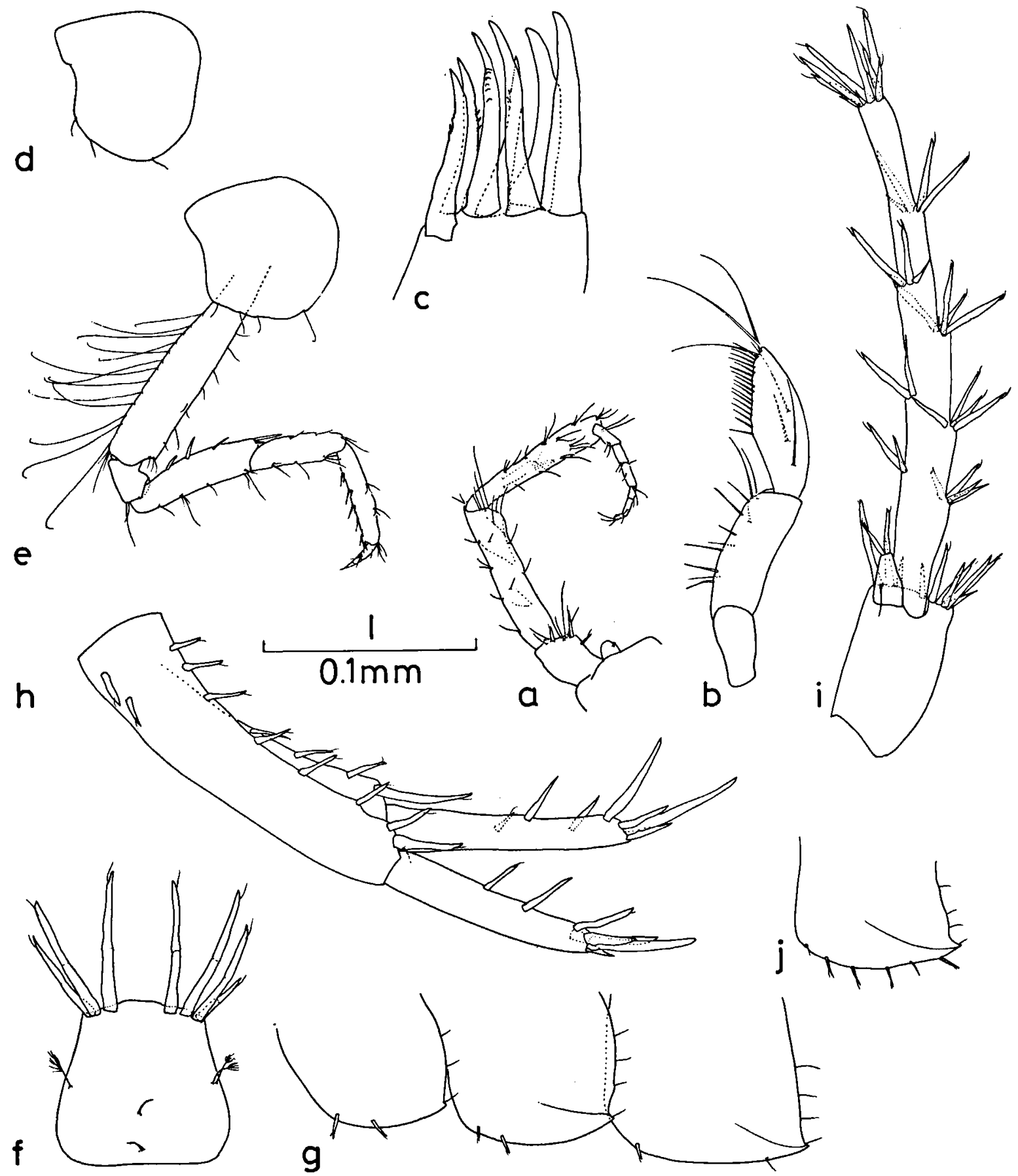

Fig. 30. Pseudoniphargus sorbasiensis $\mathrm{n}$. sp. (a-g, $९$ holotype $9.0 \mathrm{~mm} ; \mathrm{h}-\mathrm{j}, ~ \&$ paratype $7.0 \mathrm{~mm}$; both from Sorbas): a, antenna 2 (scale A); b, mandible palp (B); c, outer lobe maxilla 1 (I); d, coxal plate pereiopod 3 (A); e, pereiopod 4 (A); f, telson (B); g, epimera (A); h, uropod 1 (B); i, uropod 3 (B); j, epimeral plate 3 (A). 


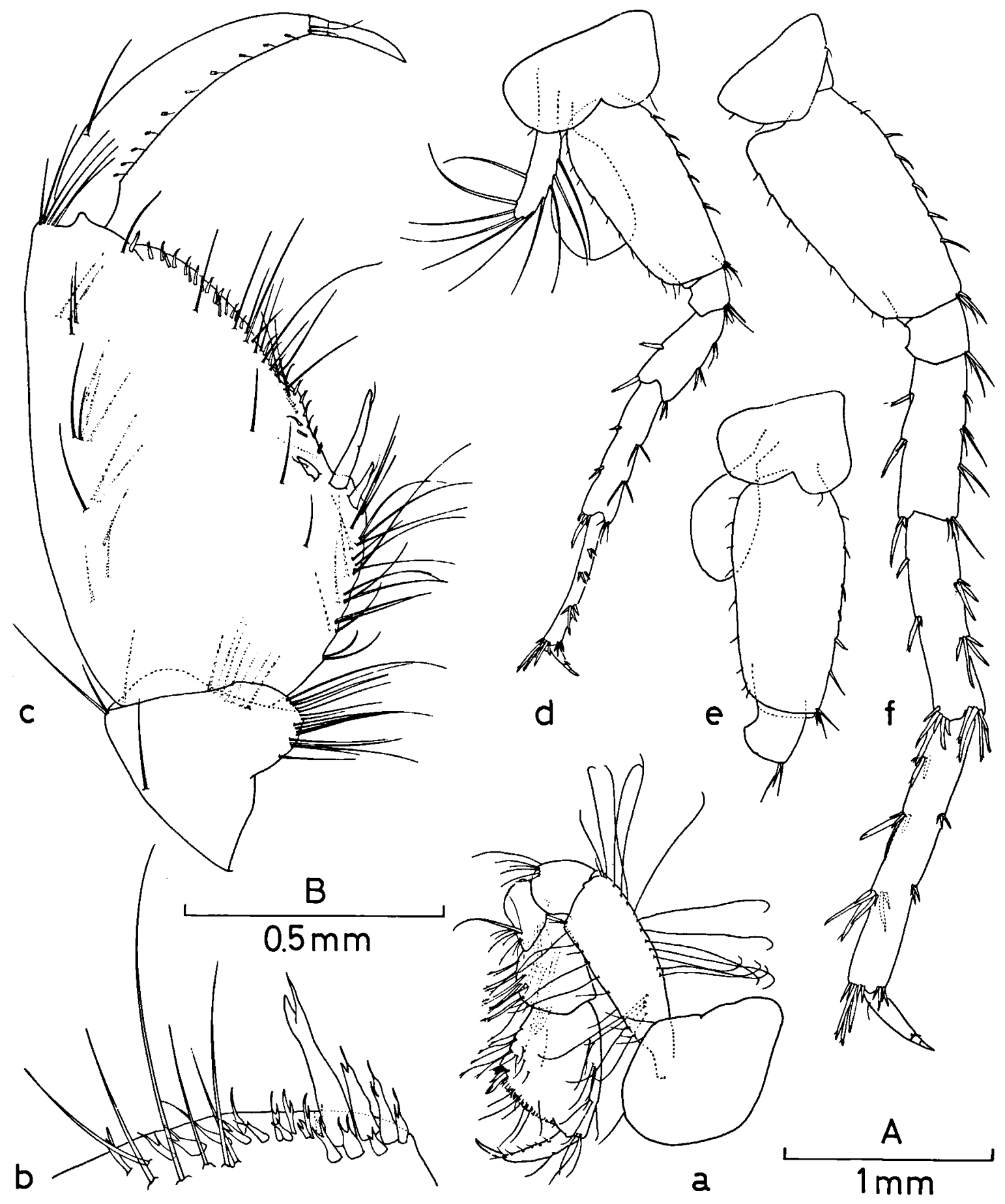

Fig. 31. Pseudoniphargus sorbasiensis n. sp., Q holotype $9.0 \mathrm{~mm}$, from Sorbas: a, gnathopod 1 (scale A); b, palmar margin gnathopod 1 (I); c, distal part gnathopod 2 (B); d, pereiopod 5 (A); e, basis pereiopod 6 (A); f, pereiopod 7 (A). 
ticulate and 3 smooth spines. Other mouthparts without peculiarities.

Gnathopod 1 (fig. 31a): coxal plate slightly longer than wide, with $1+2$ distal setae; carpus shorter than propodus, posteriorly with 5-6 setal rows; palmar angle (fig. $31 \mathrm{~b}$ ) in $9.0 \mathrm{~mm}$ large specimen with 7 spines, smaller specimens with 5 spines. Gnathopod 2: coxal plate wider than that of gnathopod 1; carpus short; propodus (fig. 31c) with 6 setal groups on posterior margin; palma very oblique, slightly $\mathrm{S}$-shaped, palmar angle with 3 spines (1 slender and 1 smaller more interiorly implanted); claw slender, unguis $1 / 4$ of length of dactylus.

Pereiopods 3 and 4 (fig. 30e): coxal plates subquadrate, plate 3 (fig. $30 \mathrm{~d}$ ) with $1+2$ distal setae, plate 4 with $1+3$ distal setae and hardly posteriorly excavate; posterior margin of propodus with 5-10 spinules; claw short, unguis as long as dactylus. Oostegites with 12-14 setae.

Pereiopods 5 to 7 (figs. $31 \mathrm{~d}-\mathrm{f}$ ): basis very slender, posterior lobe narrow and nonoverhanging, with obtuse posterodistal angle, margins straight, anterior one with 5-7 elements and posterior one with 8-12 setules; pereiopod 6 as long as pereiopod 7; claw short, unguis 2/3 (in P5) and 2/5 (in P7) of length of dactylus.

Epimera (fig. 30g): lower margin of plates 1 and 2 both with 2 spines, that of plate 3 with 1 spine and 1 setule, sometimes with 4 spines and 2 setules (fig. $30 \mathrm{j}$ ); posteroventral corner rectangular with a small tooth; posterior margin bearing some long setules, that of plates 1 and 2 slightly convex, that of plate 3 straight.

Uropod 1 (fig. 30h): peduncle with 2 basoventral spines, a dorsal row of 6 spines, 3 medial spines, and distomedial spine reaching up to $1 / 3$ of length of endopodite; exopodite slightly shorter than endopodite, both rami with marginal armature and slender terminal spines. Uropod 2: peduncle with 2 dorsal spines, and 1 distal spine on either side; exopodite slightly shorter than endopodite. Uropod 3 (fig. 30i): peduncle almost twice as long as wide, with numerous distal spines; endopodite with 2 rather long terminal spines; exopodite about 10 times as long as wide, margins with $3-4$ groups of long spines, each group of 2-6 spines, terminal spines as long as marginal spines.

Telson (fig. 30f): about as long as wide, tapering, distal margin straight or slightly convex, with 3-4 long spines on either side.

Male: Only one small specimen available, which is (except for some small details in chaetotaxy) similar to the female.

Remarks. - This species has a slender basis of pereiopods 5 to 7 with a narrow nonoverhanging posterior lobe, and a non-elongate male exopodite of uropod 3 . In these characters it is similar to unisexualis and spiniferus from northern Spain, and with latipes and fragilis from southern Spain. It differs from these species in the very short flagellum of antenna 2 and the shape of the telson. Additionally Ps. sorbasiensis differs from unisexualis and spiniferus in the strongly oblique palma of gnathopod 2, spinous distal margin of the epimera, heavily spinose uropod 1, and the length and armature of the exopodite of uropod 3. Moreover, aberrant features of latipes are the length of mandible palp segment 3 , number of multidenticulate spines on the outer lobe of maxilla 1 , width of the propodus of gnathopod 1 , and length of the claws of the pereiopods. Ps. fragilis differs mainly from sorbasiensis in the sexually dimorphic gnathopod 2, slender coxae 3 and 4 in the female, and the shape of the epimera.

Etymology. - The proposed name sorbasiensis is a toponym alluding to the small town of Sorbas, in the surroundings of which this species was found.

\section{Pseudoniphargus sp. 2}

(Fig. 32)

Material examined. - Prov. Almería, Pujaire, well E. of the road Almería-El Cabo de Gata, $3.5 \mathrm{~km} \mathrm{~N}$. of El Cabo de Gata, UTM coordinates WF6874, alt. 20 m; 19 Jan. 1984 (sta. 84-1/27), 3 specimens.

Prov. Almería, Nijar, well S. of the main road at Las Negras, $500 \mathrm{~m}$ from the sea, UTM coordinates WF848199, alt. $10 \mathrm{~m}$; 21 July 1985 (sta. 85-7/20), 10 specimens. 

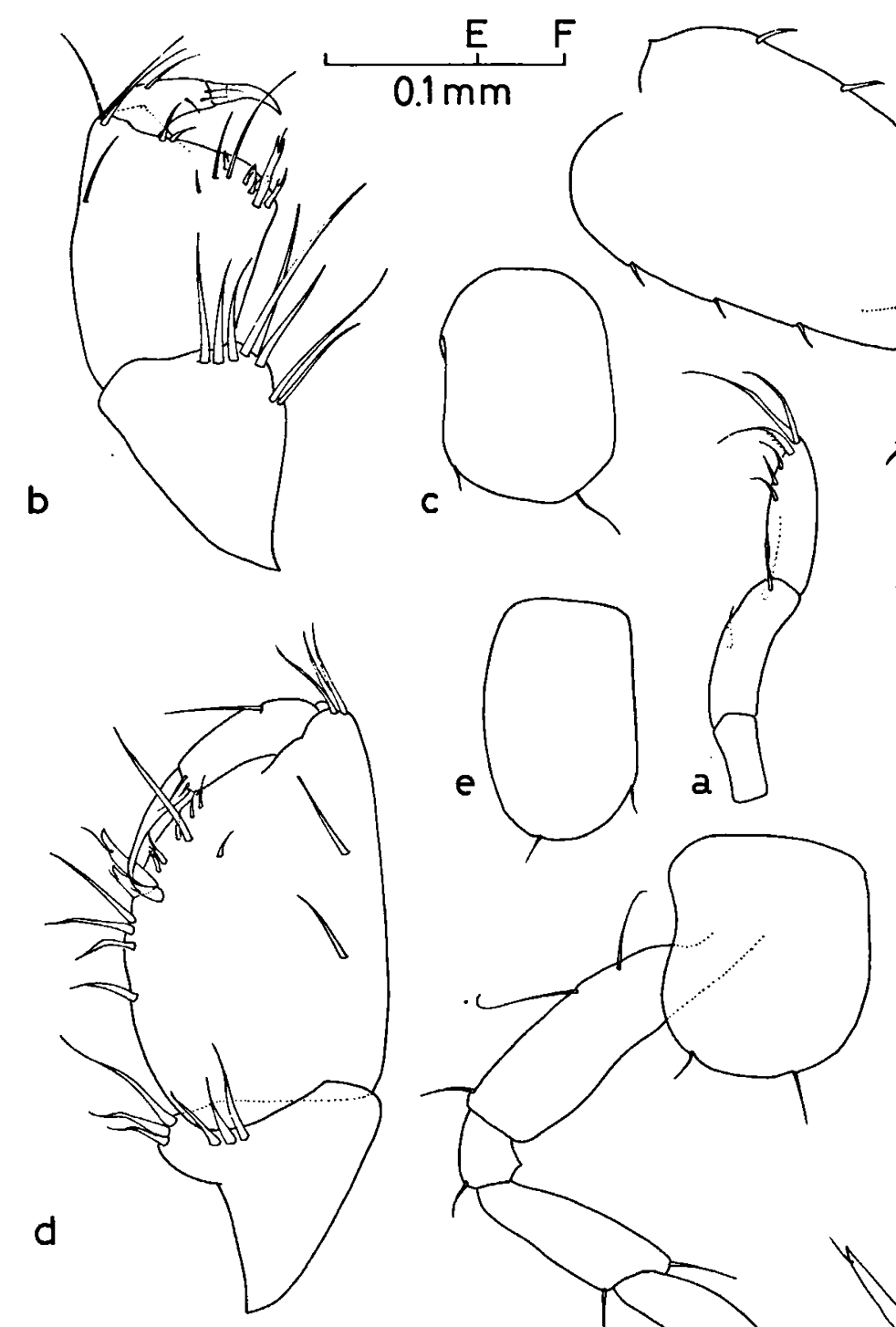
Prov. Almería, Nijar, well at Las Negras, N. of the main road, $600 \mathrm{~m}$ from the sea, UTM coordinates WF883822, alt. $10 \mathrm{~m}$; 21 July 1985 (sta. 85-7/21), 2 specimens.

Remarks. - Only very small specimens, not exceeding $2.0 \mathrm{~mm}$ in length, were available for study. Although difficult to classify because of their probable immature nature this material warrants special attention. Remarkable features are the mandible palp (fig. 32a) and the appendages (figs. 32f, g) which are poorly armed, the well-developed posterior lobe of the basis (figs. $32 \mathrm{~g}, \mathrm{~h}$ ) and slender claws of pereiopods 5 to 7 , and the shape and armature of the telson (fig. 32k).

Additionally illustrated are distal parts of gnathopods (figs. 32b, d), coxae 1 and 3 (figs. 32c, e), epimeral plates 2 and 3 (fig. 32-1), and uropods 1 and 3 (figs. 32i, j).

In several of these features, but above all in the telson, this material resembles an unnamed Pseudoniphargus from cave waters in the Rhar-elKhal, wilaya Tlemcen, N.W. Algeria (Pseudoniphargus sp. 1 of Stock, 1980).

The Algerian locality was visited again by the "Biospeleologische Werkgroep" in 1981. At this time numerous specimens were collected, all very small-sized (up to approximately 4.0 $\mathrm{mm}$ ). Another point of resemblance between this material and the Algerian form is therefore probably their small size.

\section{Pseudoniphargus fragilis $\mathrm{n}$. sp.}

(Figs. 33-35)

Material examined. - Prov. Málaga, Tolox, well at Las Mallanas, near Central Eléctrica de San Eugenio, UTM coordinates UF 323637, alt. $240 \mathrm{~m} ; 11$ July 1985 (sta. A85-7/30), 1 o holotype, 1 \& allotype, 5 ơ $0^{\circ}, 4$ 우 (1 ovigerous), and 29 other specimens (paratypes) (ZMA coll. no. Amph. 108.132).

Prov. Málaga, Tolox, SBR Río de los Caballos, near Fuente Amorgosa, UTM coordinates UF295610, alt. 300 m; 11 July 1985 (sta. A85-7/29), 2 ○० , 2 \& , 2 damaged specimens, and 3 juvs. (paratypes) (ZMA coll. no. Amph. 108.138).

Prov. Granada, Salar, SBR Arroyo del Salar near Barranco del Troncón, about $1 \mathrm{~km} \mathrm{~S}$. of Salar, UTM coordinates VG056113, alt. $550 \mathrm{~m}$; 19 July 1985 (sta. A85$7 / 59$ ), 2 \% ${ }^{\circ}, 3$ ㅇ , and 1 juv. (probably belonging to this species).
Description. - Largest male and female (from Tolox) 6.0 and $5.7 \mathrm{~mm}$, respectively; ovigerous female $5.5 \mathrm{~mm}$, carrying 4 eggs. Largest female from Salar $6.0 \mathrm{~mm}$.

Male: Antenna 1 about half of body length; peduncle shorter than that of antenna 2; flagellum 14- to 19-segmented, aesthetascs 1/2$1 / 3$ of length of corresponding segments. Antenna 2 (fig. 33a): peduncle slender, segment 4 with several rather long spines; flagellum 6- to 7-segmented, as long as peduncle segment 5 .

Mandible palp (fig. 34a): segment 2 with setose ventral margin; segment 3 with 1 A-seta, 2-3 B-setae, 15 D-setae, and 3 E-setae. Spines on outer lobe of maxilla 1 (fig. 34b) paucidenticulate. Other mouthparts without peculiarities.

Gnathopod 1 (fig. 34c): strong in largest male (holotype), in smaller males slender; carpus shorter than propodus with 4 setal rows on posterior margin; propodus robust, distally somewhat widened in the largest male. Gnathopod 2 (fig. 33b): coxal plate rather wide (similar to that of gnathopod 1) with $1+2$ distal setae; carpus short; propodus with oblique palma, palmar margin convex, its corners with 3 spines (1 long and 1 small interiorly implanted); unguis $1 / 4$ of length of dactylus.

Pereiopods 3 and 4: coxal plate rather wide; plate 3 (fig. 33c) with $1+2$ and plate 4 (fig. 33d) with 4 long distal setae; posterior excavation of plate 4 shallow; posterior margin of propodus (fig. 33e) with 5-6 spinules.

Pereiopods 5 and 6 (figs. 34d, e) slender (distal segments of pereiopod 7 lacking in all specimens); basis of pereiopods 5 to 7 (figs. 33f, $34 \mathrm{~d}$, e) in the largest male (holotype) slender with narrow and non-overhanging posterior lobe, margins straight, with about 7 elements anteriorly, and some 10 setules posteriorly. Basis of smaller males (figs. $33 \mathrm{~h}-\mathrm{j}$ ) with wider posterior lobe and convex margins. Distal propodal spine as long as claw; claw not elongated, unguis $1 / 2$ of length of dactylus (figs. 34d, e).

Epimera (fig. $33 \mathrm{~g}$ ): lower margin of plates 2 and 3 with 1 and 2 slender spines, respectively; 

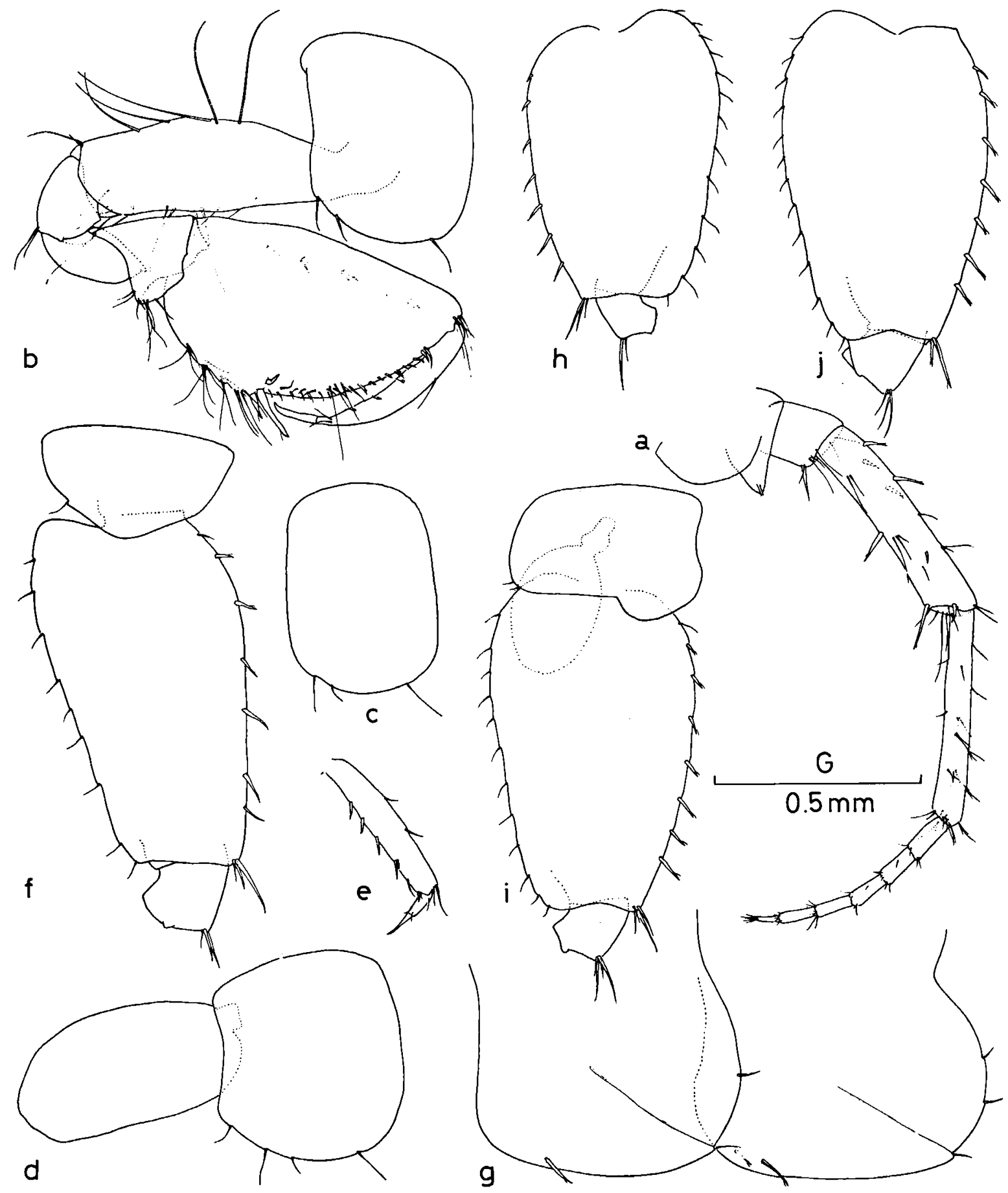

Fig. 33. Pseudoniphargus fragilis $\mathrm{n}$. sp. (a-g, o holotype $6.0 \mathrm{~mm}$; h-j, ơ paratype $5.8 \mathrm{~mm}$; both from 'lolox): a, antenna 2 (scale G); b, gnathopod $2(\mathrm{G})$; c, coxal plate pereiopod $3(\mathrm{G})$; d, coxal plate pereiopod 4 (G); e, distal part pereiopod 4 (G); f, basis pereiopod $7(G)$; g, epimeral plates 2 and $3(G) ; h$, basis pereiopod $5(G)$; i, basis pereiopod 6 (G); j, basis pereiopod $7(\mathrm{G})$. 


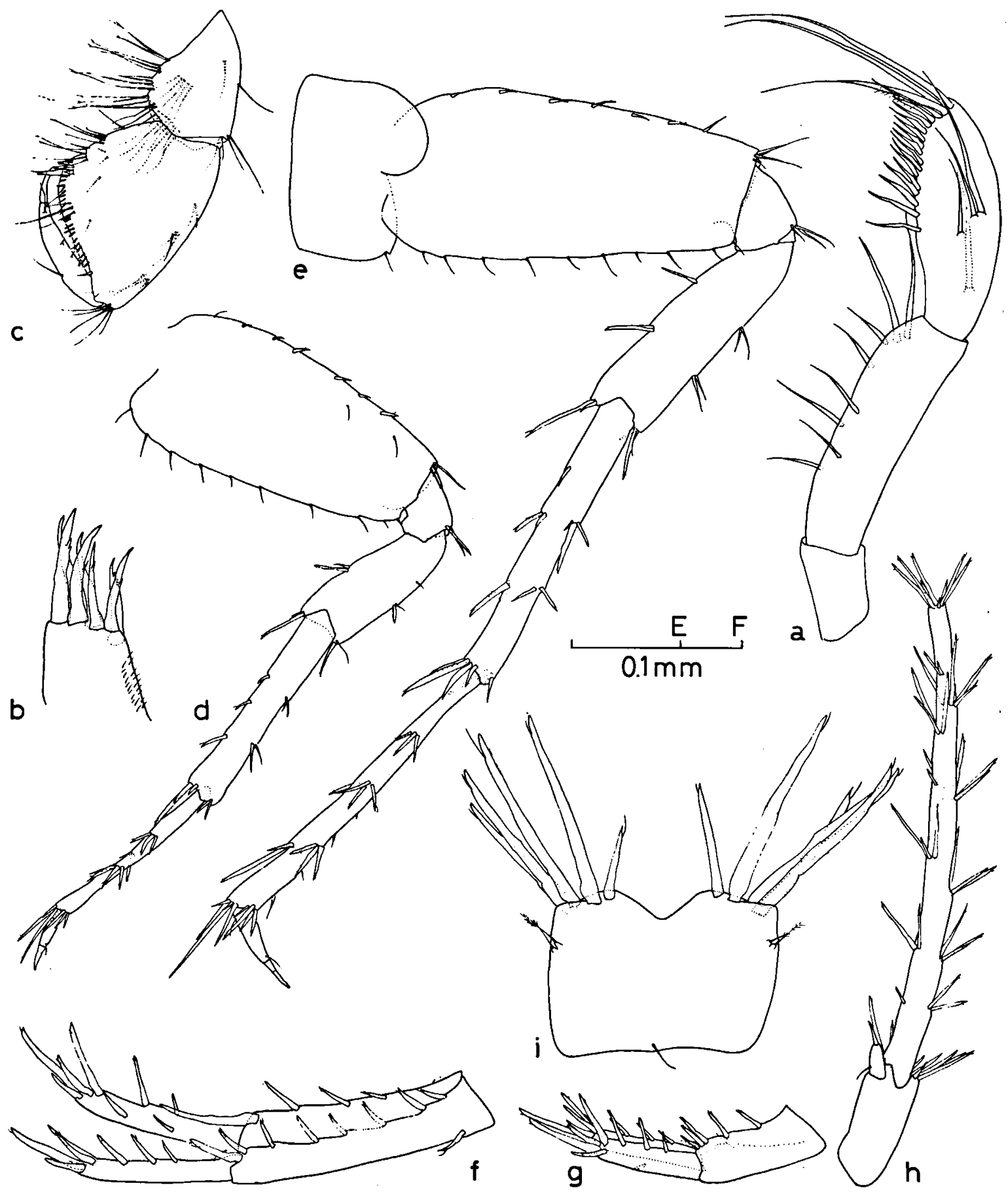

Fig. 34. Pseudoniphargus fragilis n. sp., o holotype $6.0 \mathrm{~mm}$, from Tolox: a, mandible palp (scale E); b, outer lobe maxilla 1 (F); c, distal part gnathopod $1(\mathrm{G})$; d, pereiopod $5(\mathrm{G})$; e, pereiopod $6(\mathrm{G})$; f, uropod 1 (G); g, uropod 2 (G); h, uropod $3(\mathrm{G})$; i, telson $(\mathrm{E})$. 


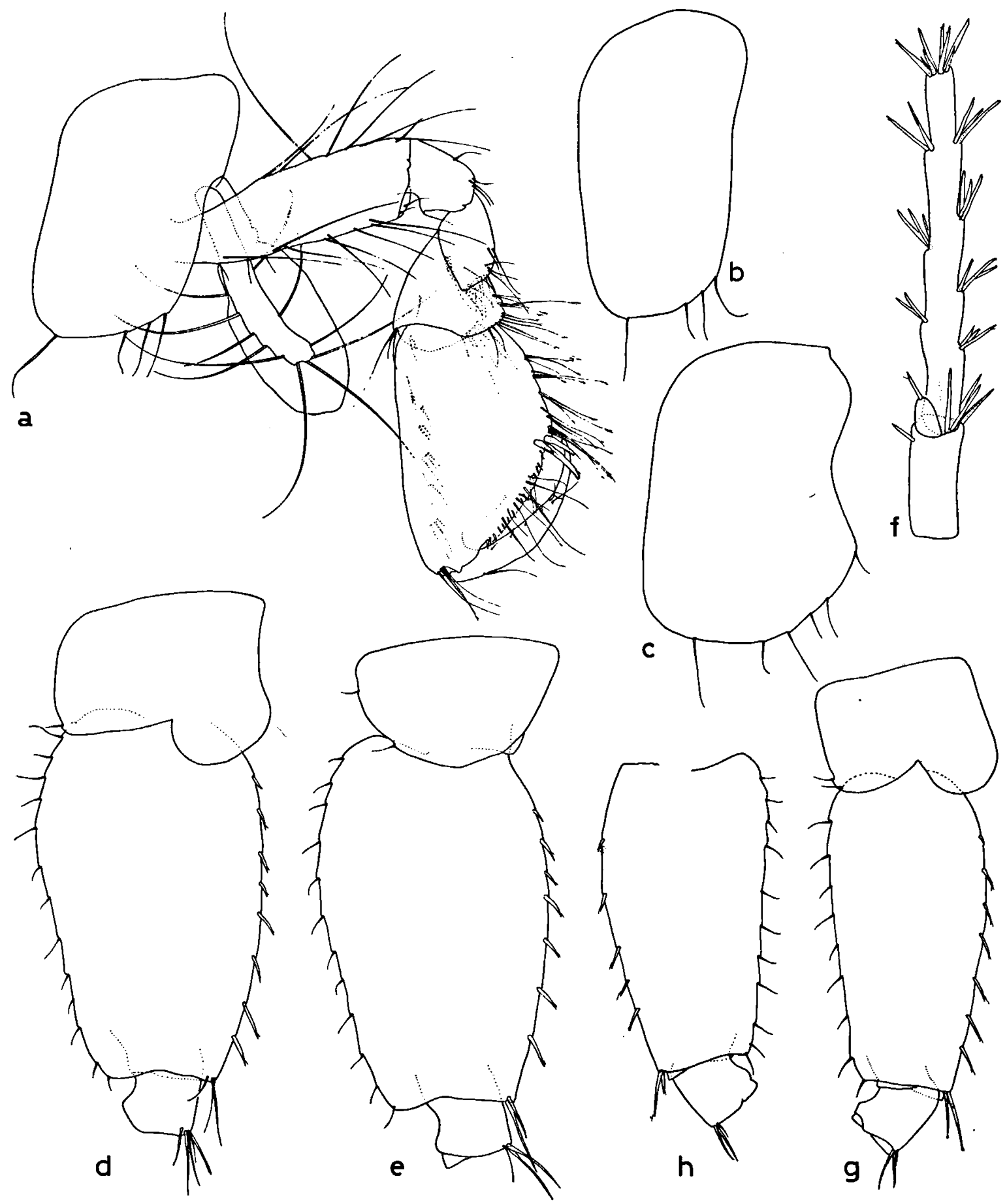

Fig. 35. Pseudoniphargus fragilis $\mathrm{n}$. sp. (a-f, $९$ allotype $5.7 \mathrm{~mm}$, from Tolox; $\mathrm{g}$-h, $९ 6.0 \mathrm{~mm}$, from Salar): a, gnathopod 2 (scale G); b, coxal plate pereiopod $3(\mathrm{G})$; c, coxal plate pereiopod $4(\mathrm{G})$; d, basis pereiopod 6 (G); e, basis pereiopod $7(\mathrm{G})$; f, uropod $3(\mathrm{G}) ; \mathrm{g}$, basis pereiopod $6(\mathrm{G})$; h, basis pereiopod $7(\mathrm{G})$. 
posteroventral corner rounded, posterior margin strongly convex with few setules.

Uropod 1 (fig. 34f) slender; peduncle with slender basoventral spine, a row of 6 slender dorsal spines, 3 medial spines, and distomedial spine reaching up to half the length of endopodite; rami with spinous margins and slender terminal spines. Uropod 2 (fig. $34 \mathrm{~g}$ ): peduncle with several dorsal spines, and 2 distal spines on either side; rami as in uropod 1. Uropod 3 (fig. $34 \mathrm{~h}$ ): peduncle 2.0-2.5 times as long as wide with long distal spines; endopodite with rather long terminal spine; exopodite about 16.5 times as long as wide, margins with 5-6 groups of spines, each group with 1-4 long spines, terminal spines as long as marginal spines.

Telson (fig. 34i) wider than long, with rather narrow, V-shaped distal notch, terminal lobes flattened with 5 long terminal spines on either side.

Female: Coxal plates 1-4 more elongated than in male (figs. 35a-c), bearing long distal setae, plate 4 (fig. 35c) with distinct posterior excavation. Gnathopod 1 slender; propodus as long as carpus, not widened distally. Gnathopod 2 (fig. 35a): propodus more slender and with less oblique palmar margin than in male.

Basis of pereiopods 5 to 7 (figs. 35d, e) slightly longer and with more marginal elements than in male, however not as slender and with wider posterior lobe than in largest male. Oostegites with 11-12 setae.

Uropod 3 (fig. 35f): endopodite sometimes with 2 long terminal spines; exopodite about 10 times as long as wide, margins with 3-4 groups of spines, each group with 2-3 long spines.

Remarks. - Sexual differences in gnathopods 1 and 2 and coxae 3 and 4, strongly convex posterior margins of the epimera, and the armature of the uropods are striking features of this species. The differences between males and females, and adults and subadults, in morphology of the basis in posterior pereiopods are remarkable. More material is necessary to decide if this feature is polymorphic, sex-linked or allometric.
In many characters the specimens from Salar look like this species. However, females from Salar disagree in having less slender coxae 3 and 4, and shorter and more slender basal segments of pereiopods 5 to 7 (figs. $35 \mathrm{~g}$-h). In the latter characters they resemble the largest male from Tolox. The specimens from Salar are therefore provisionally classified with this species.

Smaller males and females from Tolox have a comparable morphology of the basis of pereiopods 5 to 7 . A strongly allometric growth is therefore likely, through which the basis becomes elongated with a narrow posterior lobe and straight margins in older males (and probably older females as well).

\section{Pseudoniphargus gibraltaricus n. sp.} (Figs. 36-37)

Material examined. - Prov. Cádiz, Jimena de la Frontera, well at Marchenilla, UTM coordinates TF824306, alt. $30 \mathrm{~m}$; 6 July 1985 (sta. A85-7/9), 1 \& holotype, 4 \&, $20^{\circ} 0^{\circ}$, and 8 juvs. (paratypes) (ZMA coll. no. Amph. 108.131).

Prov. Cádiz, San Roque, SBR Río Guadiaro, near bridge of the road N-340 from San Roque to Estepona, 12 km N.E. of San Roque, UTM coordinates TF952194, alt. 5 m; 7 July 1985 (sta. A85-7/15), 1 o allotype, 4 O'ơ, 9 $९ ९$ (2 ovigerous), and 9 juvs. (paratypes) (ZMA coll. no. Amph. 108.130).

Prov. Cádiz, Jimena de la Frontera, well at Marchenilla, UTM coordinates TF825298, alt. $30 \mathrm{~m}$; 6 July 1985 (sta. A85-7/11), 1 juv. (probably this species).

Description. - Largest female $7.0 \mathrm{~mm}$ from Marchenilla, ovigerous females ranging from 3.5 to $5.5 \mathrm{~mm}$; largest male $4.0 \mathrm{~mm}$ from Río Guadiaro.

Female: Antenna 1 slightly shorter than total body length; peduncle about as long as that of antenna 2, poorly setose; flagellum 14- to 17 segmented, aesthetascs slightly shorter than $1 / 2$ the length of corresponding segments. Antenna 2 (fig. 36h): peduncle segment 3 with 1 long distal spine, segment 4 with some long distal spines, segment 5 with rather long setae; flagellum 5- to 7-segmented, about twice as long as peduncle segment 5 .

Mandible palp (fig. 36a) slender, ventral surface of segment 2 sparsely setose, segment 3 


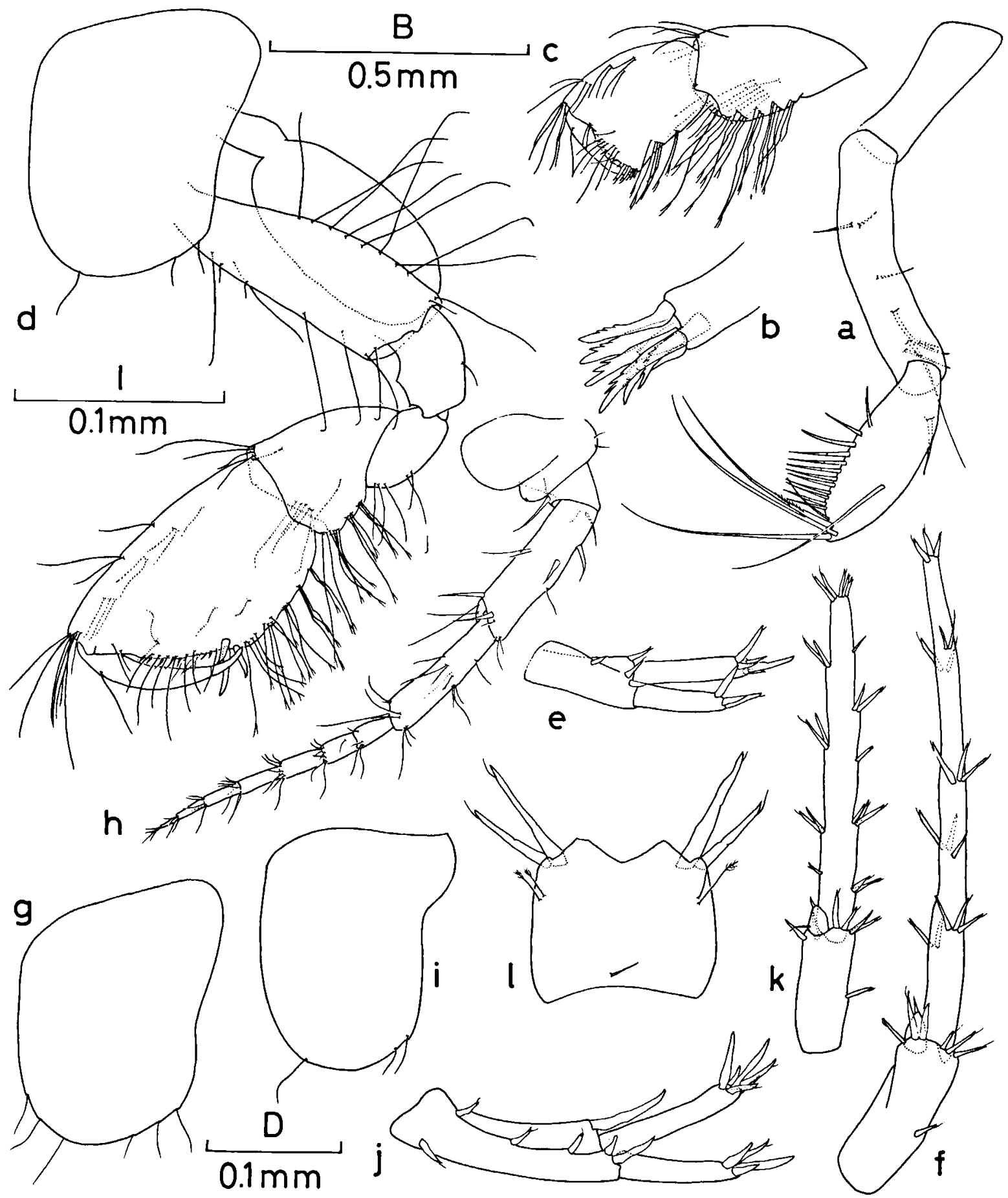

Fig. 36. Pseudoniphargus gibraltaricus n. sp. (a-b, $\$$ holotype $6.5 \mathrm{~mm}$, from Marchenilla; $\mathrm{c}-\mathrm{g}$, $\$$ paratype $7.0 \mathrm{~mm}$, from Marchenilla; h-k, $\odot$ paratype $5.5 \mathrm{~mm}$, from San Roque; 1 , $\sigma^{*}$ allotype $4.0 \mathrm{~mm}$, from San Roque): a, mandible palp (scale D); b, outer lobe maxilla 1 (I); c, distal part gnathopod 1 (B); d, gnathopod 2 (B); e, uropod 2 (B); f, uropod 3 (B); g, coxal plate gnathopod 1 (B); h, antenna 2 (B); i, coxal plate pereiopod 3 (B); j, uropod 1 (B); k, uropod 3 (B); 1, telson (D). 


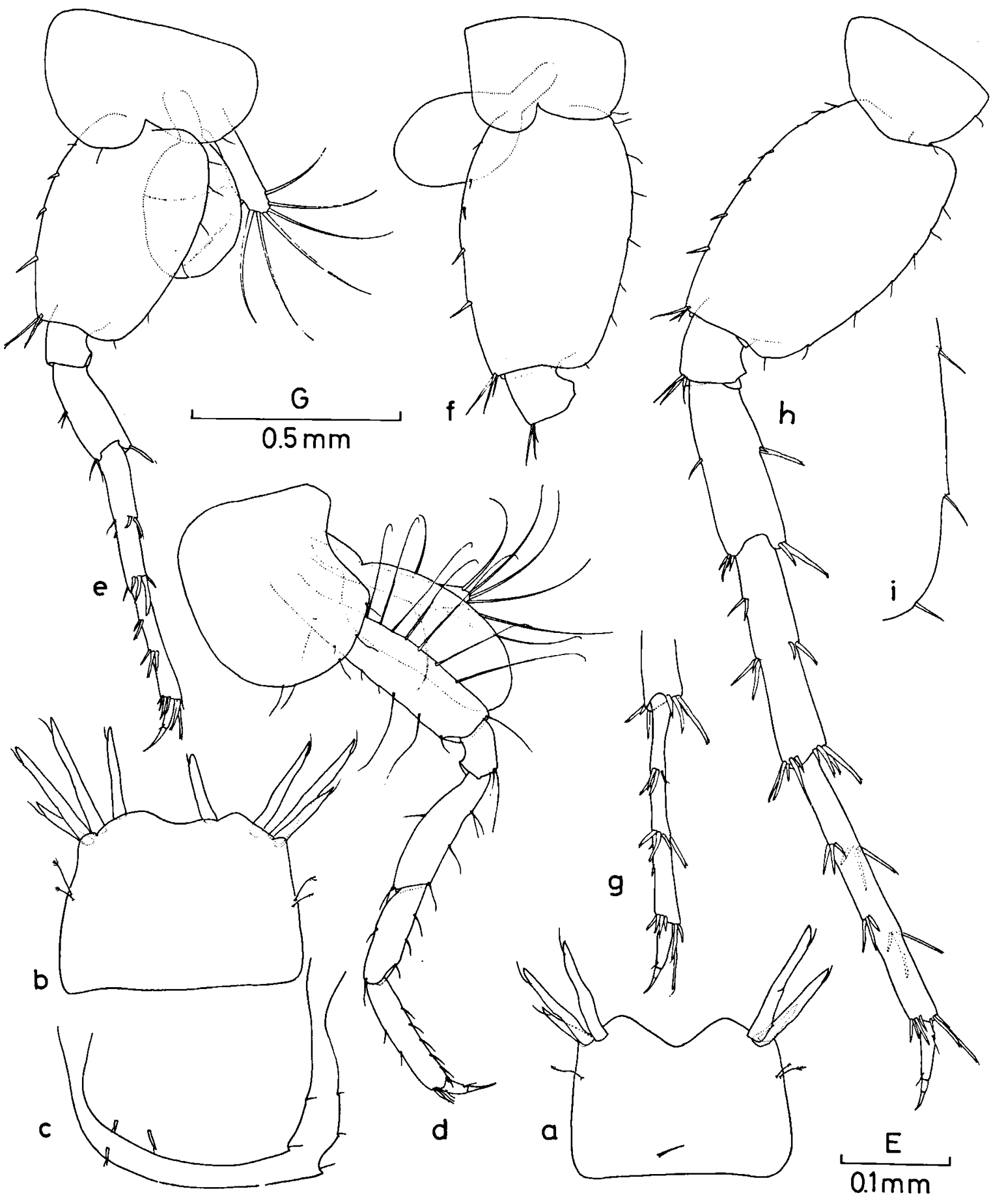

Fig. 37. Pseudoniphargus gibraltaricus n. sp. (a, $९$ holotype $6.5 \mathrm{~mm}$, from Marchenilla; b-c, $९$ paratype $7.0 \mathrm{~mm}$, from Marchenilla; d-i, ovigerous $\$$ paratype $5.5 \mathrm{~mm}$, from San Roque): a, telson (scale E); b, telson (E); c, epimeral plates 2 and $3(\mathrm{G})$; d, pereiopod $4(\mathrm{G})$; e, pereiopod $5(\mathrm{G})$; f, basis pereiopod $6(\mathrm{G})$; g, distal part pereiopod $6(\mathrm{G})$; h, pereiopod 7 (G); i, distal part posterior margin basis pereiopod 7 (E). 
short with 1 short A-seta, 1 short and/or 1 long B-setae, 11-13 slender D-setae, and $3 \mathrm{E}$-setae. Spines on the outer lobe of maxilla 1 (fig. 36b) multidenticulate. Other mouthparts without peculiarities.

Gnathopod 1: coxal plate (fig. 36g) subrectangular with $3+3$ distal setae (smaller females with $1+2$ distal setae); carpus (fig. 36c) slightly longer than propodus with 5 setal rows on posterior margin. Gnathopod 2 (fig. 36d): coxal plate with 1-2 + 2 distal setae; carpus short; propodus rather slender; palmar margin slightly oblique; unguis about $1 / 3$ of length of dactylus.

Pereiopods 3 and 4 (fig. 37d): coxal plate 3 (fig. 36i) with $1+2$ distal setae, plate 4 rather wide, with distinct posterior excavation and 5 distal setae, propodus with 4 and 5 setae on posterior margin, respectively; claw short, unguis as long as dactylus. Oostegites with 8-9 setae.

Pereiopods 5 to 7 (figs. $37 \mathrm{e}-\mathrm{i}$ ): basis with wide posterior lobe, slightly overhanging, and convex margins; basis of pereiopod 5 (fig. 37e) the widest, shorter than those of pereiopods 6 and 7 (figs. 37f, h), margins without many elements, spinules on anterior margin progressively longer distally; number of spines on distal segments increasing and gradually longer from pereiopod 5 to 7 (figs. 37e, g, h), distal propodal spines not exceeding the length of the claw; claw of pereiopod 5 rather short with unguis as long as dactylus, claws of pereiopods 6 and 7 more slender with unguis about $1 / 3$ of dactylus.

Epimera (fig. 37c): distal margin of plate 2 with $0-1$, and that of plate 3 with 1-2 small spines, posteroventral corner with small tooth, posterior margin convex with few setules.

Uropod 1 (fig. 36j): peduncle with strong basoventral spine, a row of 3 dorsal spines, no medial spines, and distomedial spine reaching beyond half the length of endopodite; rami without spinous margins, exopodite shorter than endopodite. Uropod 2 (fig. 36e): peduncle with 1 or 2 dorsal spines, and 1-2 distal spines on either side; margins of rami unarmed, exopodite shorter than endopodite. Uropod 3 (figs. 36f, k): peduncle about 2.3-3.0 times as long as wide, with one lateral spine; exopodite about 14 times as long as wide, slightly tapering, margins with 4 spine groups, each group consisting of 1-3 spines, which are about as long as the width of the exopodite, and few terminal spines which are shorter than marginal spines.

Telson (figs. 37a, b) wider than long, with rather deep $\mathrm{V}$-shaped distal emargination and 2-3 subterminal spines on either side. Largest female $(7.0 \mathrm{~mm})$ with shallow distal notch and 2 additional spines, implanted more distomedially.

Male: Similar to female but apparently smaller. The telson is shown in fig. 36-1.

Remarks. - Ps. gibraltaricus cannot be placed in any of the taxa belonging to the group of species (longispinum, mateusorum, margalefi, and cazorlae) which possess, just as gibraltaricus, a non-elongate uropod 3 in the male, an ovoid basis of the posterior pereiopods with weakly developed posterior lobe, non-elongate gnathopods, and coxal plate 4 slightly wider than plate 3 . It does not possess unique features by which it is characterized, but it is described as a new taxon by its combination of characters: weakly spinose uropods, outer lobe of maxilla 1 with multidenticulate spines, marginal armature of peduncle and slender slightly tapering exopodite of uropod 3.

Etymology. - The proposed specific name gibraltaricus is a toponym alluding to the area just north of Gibraltar where the species was found.

\section{Pseudoniphargus sp. 3}

(Fig. 38)

Material examined. - Prov. Málaga, Estepona, SBR Río Padrón near bridge in the road N-340, $3.2 \mathrm{~km}$ E.N.E. of Estepona, UTM coordinates UF113347, sea level; 8 July 1985 (sta. A85-7/20), 2 १९, 1 damaged specimen, and 5 juvs.

Prov. Málaga, Casares, SBR Arroyo de la Parilla, just N.W. of the road N-340, UTM coordinates UF008284, alt. $10 \mathrm{~m} ; 7$ July 1985 (sta. A85-7/16), 1 juv.

Prov. Málaga, Casares, SBR Arroyo de la Jornada, near bridge in the road $\mathrm{N}-340$, UTM coordinates UF018290, sea level; 7 July 1985 (sta. A85-7/18), 1 juv. 

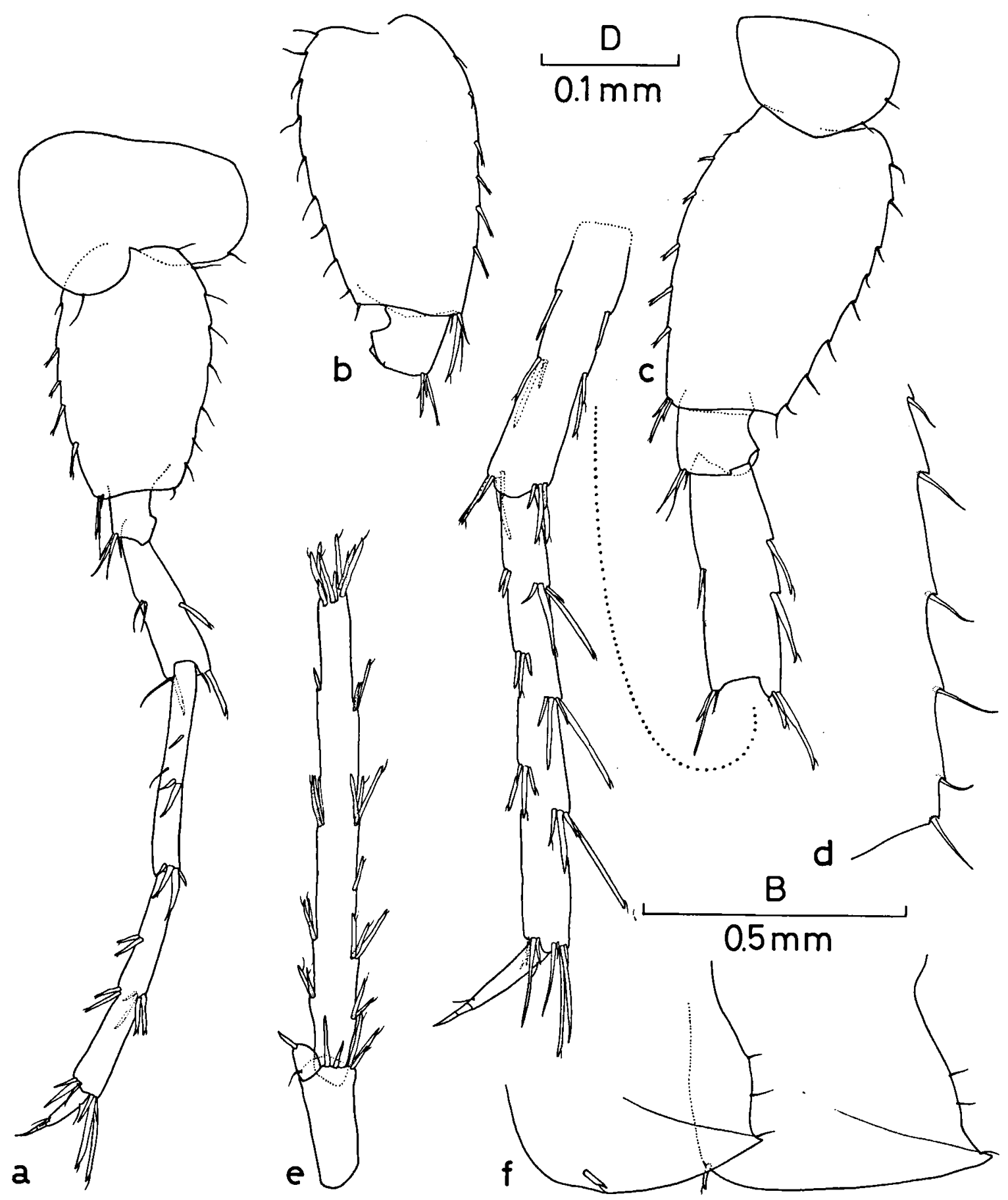

Fig. 38. Pseudoniphargus sp. 3 (a-e, $95.0 \mathrm{~mm}$; f, $95.3 \mathrm{~mm}$; both from Río Padrón): a, pereiopod 5 (scale B); b, basis pereiopod 6 (B); c, pereiopod 7 (B); d, distal part posterior margin basis pereiopod 7 (D); e, uropod 3 (B); f, epimeral plates 2 and $3(\mathrm{~B})$. 


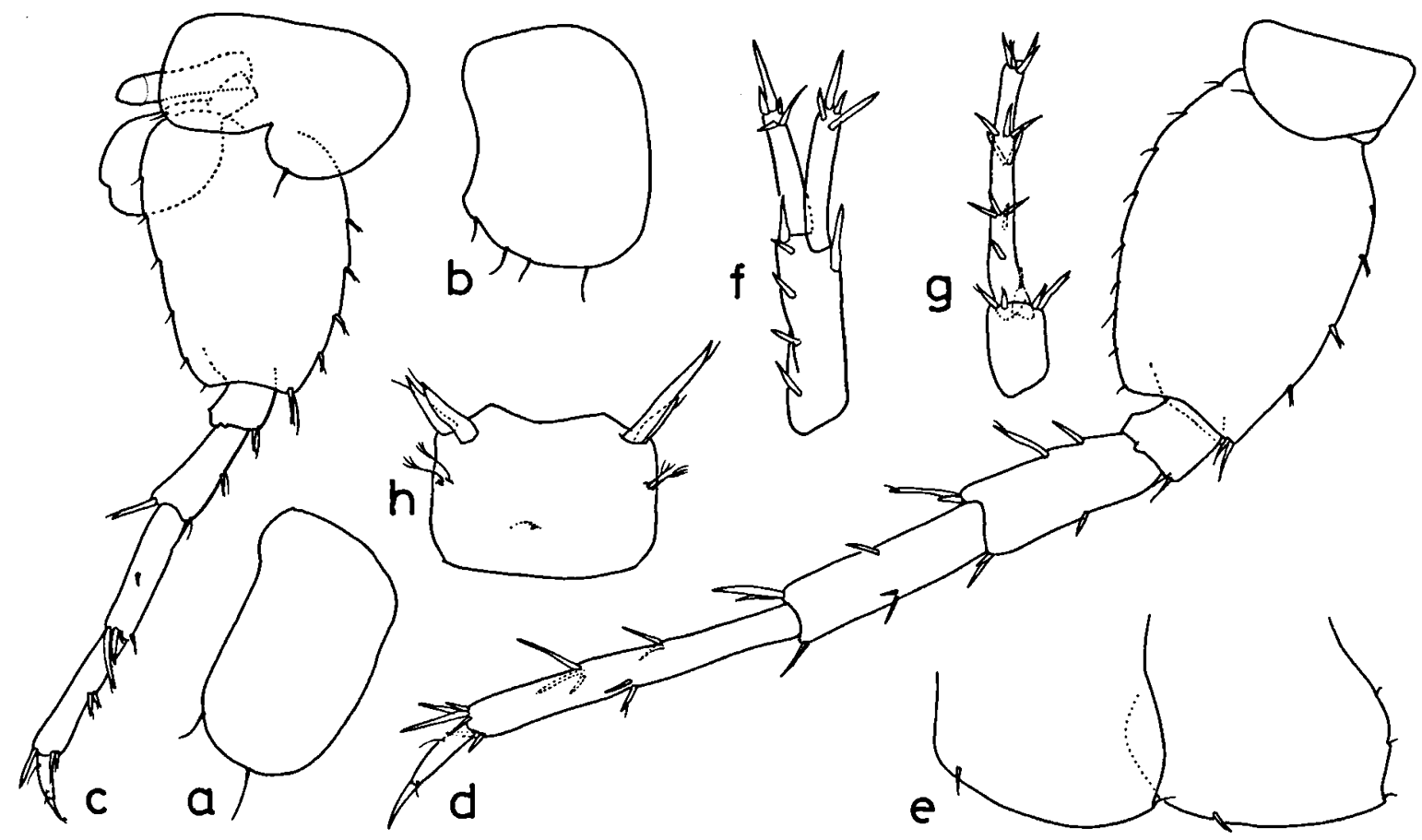

Fig. 39. Pseudoniphargus sp. 5, $\$ 3.6 \mathrm{~mm}$, from Esparteros: a, coxal plate pereiopod 3 (scale B); b, coxal plate pereiopod 4 (B); c, pereiopod 5 (B); d, pereiopod 7 (B); e, epimeral plates 2 and 3 (B); f, uropod 1 ( B); g, uropod 3 (B); h, telson (B).

Prov. Málaga, Estepona, well at El Velerin, N.W. of the road N-340, $5 \mathrm{~km} \mathrm{E.N.E.} \mathrm{of} \mathrm{Estepona,} \mathrm{UTM} \mathrm{coor-}$ dinates UF127359, alt. 10 m; 8 July 1985 (sta. A85-7/19), 1 juv.

Remarks. - In the absence of males these specimens are hard to identify. In many characters the females resemble gibraltaricus but differ from the latter as follows: posterior pereiopods (figs. 38a-c) more slender with posterodistal angle of basis angular, and particularly in $\mathrm{P7}$ the setules on the posterior margin are implanted in clear notches (fig. 38d); posteroventral corner of epimera (fig. 38f) more pronounced; and uropod 3 (fig. 38e) without lateral spine on peduncle and with longer spines on exopodite.

\section{Pseudoniphargus sp. 4}

Material examined. - Prov. Málaga, Marbella, SBR Arroyo de Víbora, $8.5 \mathrm{~km}$ E. of Marbella, UTM coordinates UF406405, alt. 15 m; 9 July 1985 (sta. A857/24), 3 \%o and 1 juv.
Remarks. - These specimens are rather similar to Pseudoniphargus sp. 3 but differ in a stronger propodus of gnathopod 2, more tapering basis of pereiopods 5 to 7 , longer spines on exopodite of uropod 3, and only 1 multidenticulate spine on the outer lobe of maxilla 1.

Because females are absent in this material, whereas males are lacking in the material of Pseudoniphargus sp. 3 , it is difficult to decide whether these specimens belong to the same species. Therefore this material remains unnamed.

\section{Pseudoniphargus sp. 5}

(Fig. 39)

Material examined. - Prov. Sevilla, $3.5 \mathrm{~km} \mathrm{S.} \mathrm{of}$ Morón de la Frontera, well near Venta de Esparteros, E. of road C-339, UTM coordinates TG8208, alt. $220 \mathrm{~m} ; 25$ July 1984 (sta. 84-7/20), 2 small ९९.

Remarks. - This material is hard to identify in the absence of males and the probable 
subadult nature of the females. Remarkable are the wide postcrior lobe of the basis of pereiopods 5 to 7 (figs. 39c, d), a character not frequently encountered among species in southern Spain. However, strongly developed lobes are better developed in smaller than in larger specimens.

Moreover, these specimens are characterized by: the outer lobe of maxilla 1 bearing 1 multidenticulate spine (remaining spines unidenticulate), slender coxal plates 1 to 3 (fig. 39a); plate 4 (fig. 39b) clearly posteriorly excavate, pereiopods 6 and 7 (fig. 39d) with slender claws; epimeral plates (fig. 39e) with small tooth on the rounded posterior corner, and convex posterior margin; uropod 1 (fig. 39f) without medial peduncle spines and no armature on the margins of the rami; uropod 3 (fig. $39 \mathrm{~g}$ ) with rather short peduncle and exopodite; and telson (fig. 39h) wider than long, with very shallow distal notch and 2 spines on either side.

\section{UNIDENTIFIABLE SPECIMENS OF PSEUDONIPHARGUS FROM SPAIN}

Juvenile or damaged specimens which appear to be Pseudoniphargus but probably do not belong to one of the species described above were found at the following stations:

Prov. Málaga, Rincón de la Victoria, SBR Arroyo de la Granadilla, 2 km N.N.E. of Rincón de la Victoria, UTM coordinates UF865661, alt. 70 m; 13 July 1985 (sta. A857/39), 3 juvs.

Prov. Málaga, Rincón de la Victoria, Well near Arroyo de la Granadilla, $2.5 \mathrm{~km}$ N.E. of Rincón de la Victoria, UTM coordinates UF8666, alt. $100 \mathrm{~m} ; 13$ July 1985 (sta. A85-7/40), 1 damaged juv.

Prov. Málaga, Nerja, SBR Barranco de Moro, $2 \mathrm{~km}$ E. of Nerja, UTM coordinates VF243686, alt. $110 \mathrm{~m} ; 15$ July 1985 (sta. A85-7/47), 6 juvs.

Prov. Granada, Jete, SBR Río Verde, UTM coordinates VF406733, alt. $100 \mathrm{~m}$; 16 July 1985 (sta. A85-7/50), 1 juv.

Prov. Granada, Huetor-Santillan, SBR Río Fardes near Venta de Molinillo, $12.5 \mathrm{~km} \mathrm{N.E.} \mathrm{of} \mathrm{Huetor-Santillan,}$ UTM coordinates VG625291, alt. $1200 \mathrm{~m} ; 18$ July 1985 (sta. A85-7/55), 1 juv.

Prov. Granada, Alhama de Granada, Fuente Pilas, 7.5 km N.W. of Alhama de Granada, UTM coordinates VG0500, alt. 970 m; 19 July 1985 (sta. A85-7/60), 1 juv.
Prov. Alicante, Callosa de Ensarriá, Fuente del Modo, situated in canyon of the Fuentes del Algar, UTM coordinates YH58, alt. ca. 180 m; 7 March 1986, 2 juvs. Leg. M. \& Th. Schuurmans.

\section{ACKNOWLEDGEMENTS}

I would express my gratitude to: Prof. Dr. J. R. Holsinger and Prof. Dr. J. H. Stock for reading the entire manuscript; Dr. T. Geel and Dr. Th. B. Roep for providing information about the geology of southern Spain, the latter made some useful remarks about parts of the manuscript; and Dr. X. Bellés for translating the summary into Spanish.

I thank Remko Leys and Peter van den Hurk for collecting important materials on which this study is based.

The investigations of the author were supported by the Foundation for Fundamental Biological Research (BION), which is subsidized by the Netherlands Organization for the Advancement of Pure Research (ZWO).

\section{REFERENCES}

Ager, D. V., 1980. The geology of Europe: i-xix, 1-535 (McGraw-Hill, London etc.).

Boutin, Cl. \& N. Coineau, in press. Pseudoniphargus maroccanus n. sp. (subterranean Amphipoda), the first representative of the genus in Morocco. Phylogenetic relationships and paleobiogeography. Crustaceana, Suppl. 13.

Chevreux, E., 1901. Amphipodes des eaux souterraines de France et d'Algérie, V. Pseudoniphargus africanus nov. gen. et sp. Bull. Soc. zool. Fr., 26: 211-216.

Margalef, R., 1970. Anfípodos recolectados en aguas subterráneas ibéricas. Speleon, 17: 63-65.

Montenat, C., 1977. Les bassins Néogènes du Levant d'Alicante et de Murcia. Stratigraphie, paléogéographie et évolution dynamique. Documents Lab. Géol. Fac. Sci. Lyon, 68: 1-345.

Moreno Calvillo, I. \& A. Castillo Martin, 1982. Sintesis hidrogeológica de Sierra Gorda (Granada). SPES, 2: 40-57.

Notenвoom, J., 1986. The species of the genus Pseudoniphargus Chevreux, 1901 (Amphipoda) from northern Spain. Bijdr. Dierk., 56 (1): 75-122.

Notenboom, J. \& I. Meijers, 1985. Investigaciones sobre la fauna de las aguas subterráneas de España: Lista de estaciones e primeros resultados. Verslagen en technische Gegevens, Inst. taxon. Zoöl. Amsterdam, 42: $1-85$.

Stock, J. H., 1980. Regression model evolution as exemplified by the genus Pseudoniphargus (Amphipoda). Bijdr. Dierk., 50 (1): 105-144. 
Stock, J. H., J. R. Holsinger, B. Sket \& Th. M. Iliffe, 1986. Two new species of Pseudoniphargus (Amphipoda), in Bermudian groundwaters. Zoologica Scr., 15 (3): 237-249.

VölK, H. R., 1967. Zur Geologie und Stratigraphie des Neogen Beckens von Vera, Südost-Spanien: 1-160 (Ph.D. thesis, University of Amsterdam).
Weijermars, R., Th. B. Roep, B. van der Eeckhout, G. Postma \& K. KleverlaAn, 1985. Uplift history of a Betic fold nappe inferred from Neogene-Quaternary sedimentation and tectonics (in the Sierra Alhamilla and Almería, Sorbas and Tabernas Basins of the Betic Cordilleras, S.E. Spain). Geol. Mijnbouw, 64: 397-411.

Received: 9 December 1986 